Andrews University

Digital Commons @ Andrews University

\title{
Selected Roles/Functions of Technical/Vocational Education Administrators in Barbados and the Need for Further Preparation and Continuing Professional Development
}

Cecil I. Cummins

Andrews University

Follow this and additional works at: https://digitalcommons.andrews.edu/dissertations

Part of the Other Teacher Education and Professional Development Commons, and the Secondary Education and Teaching Commons

\section{Recommended Citation}

Cummins, Cecil I., "Selected Roles/Functions of Technical/Vocational Education Administrators in Barbados and the Need for Further Preparation and Continuing Professional Development" (1997).

Dissertations. 307.

https://digitalcommons.andrews.edu/dissertations/307

https://dx.doi.org/10.32597/dissertations/307

This Dissertation is brought to you for free and open access by the Graduate Research at Digital Commons @ Andrews University. It has been accepted for inclusion in Dissertations by an authorized administrator of Digital Commons@ Andrews University. For more information, please contact repository@andrews.edu. 


\section{Andrews \$university}

Seek Knowledge. Affirm Faith. Change the World.

Thank you for your interest in the

\section{Andrews University Digital Library of Dissertations and Theses.}

Please honor the copyright of this document by not duplicating or distributing additional copies in any form without the author's express written permission. Thanks for your cooperation. 


\section{INFORMATION TO USERS}

This manuscript has been reproduced from the microfilm master. UMI films the text directly from the original or copy submitted. Thus, some thesis and dissertation copies are in typewriter face, while others may be from any type of computer printer.

The quality of this reproduction is dependent upon the quality of the copy submitted. Broken or indistinct print, colored or poor quality illustrations and photographs, print bleedthrough, substandard margins, and improper alignment can adversely affect reproduction.

In the unlikely event that the author did not send UMI a complete manuscript and there are missing pages, these will be noted. Also, if unauthorized copyright material had to be removed, a note will indicate the deletion.

Oversize materials (e.g., maps, drawings, charts) are reproduced by sectioning the original, beginning at the upper left-hand corner and continuing from left to right in equal sections with small overlaps. Each original is also photographed in one exposure and is included in reduced form at the back of the book.

Photographs included in the original manuscript have been reproduced xerographically in this copy. Higher quality $6 " \times 9$ " black and white photographic prints are available for any photographs or illustrations appearing in this copy for an additional charge. Contact UMI directly to order.

\section{UMI}

A Bell \& Howell Information Company 300 North Zeeb Road, Ann Arbor MI 48106-1346 USA

$313 / 761-4700 \quad 800 / 521-0600$ 
Andrews University

School of Education

\title{
SELECTED ROLES/FUNCTIONS OF TECHNICAL/VOCATIONAL EDUCATION ADMINISTRATORS IN BARBADOS AND THE NEED FOR FURTHER PREPARATION AND CONTINUING PROFESSIONAL DEVELOPMENT
}

\author{
A Dissertation \\ Presented in Partial Fulfillment \\ of the Requirements for the Degree \\ Doctor of Philosophy
}

by

Cecil I. Cummins

October 1997 
UNI Number: 9815565

Copyright 1997 by

Cummins, Cecil I.

All rights reserved.

UMI Microform 9815565

Copyright 1998, by UMI Company. All rights reserved.

This microform edition is protected against unauthorized copying under Title 17, United States Code.

\section{UMI \\ 300 North Zeeb Road \\ Ann Arbor, MI 48103}


CCopyright by Cecil I. Cummins 1997 All Rights Reserved 


\section{Selected Roles/Functions of Technical/Vocational Education Administrators in Barbados and the Need for Further Preparation and Continuing Professional Development}

A dissertation

presented in partial fulfiliment

of the requirements for the degree

Doctor of Philosophy

by

Cecil I. Cummins

APPROVAL BY THE COMMITTEE:
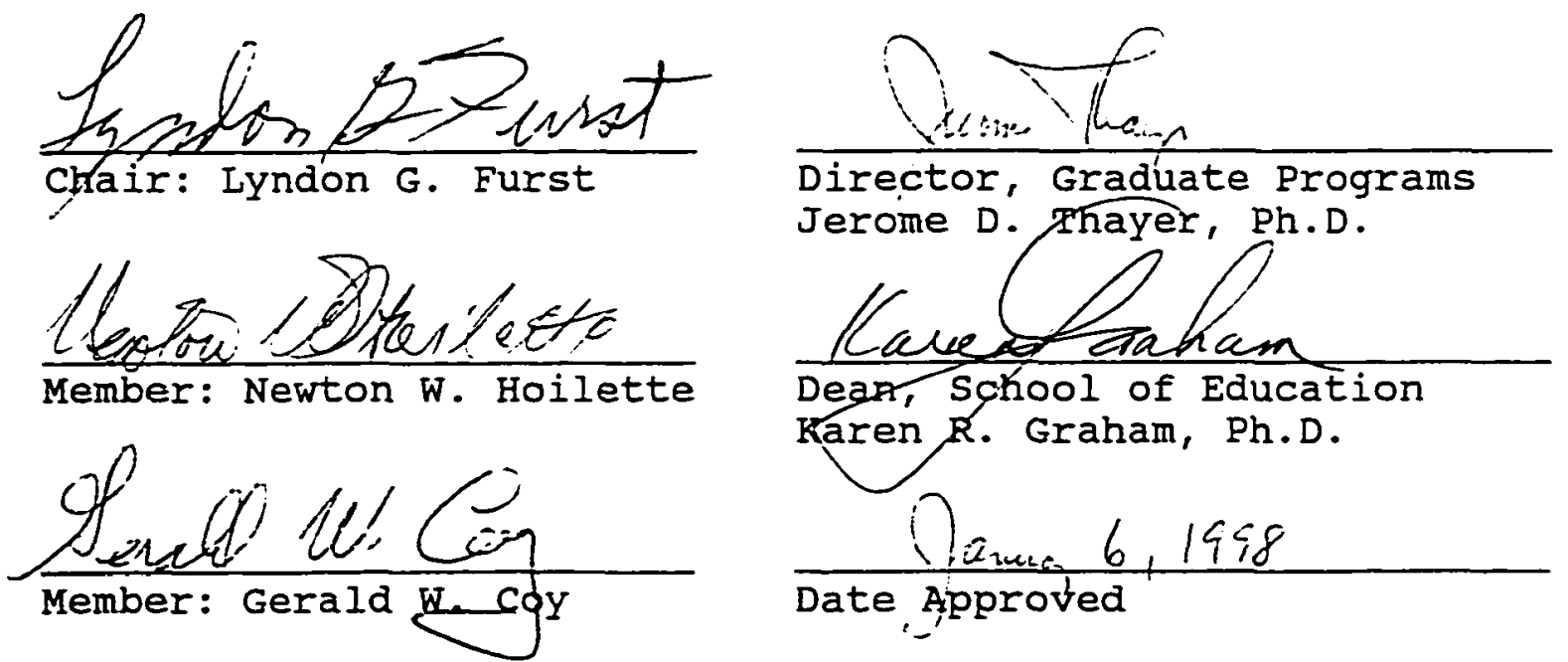

Date Approved 


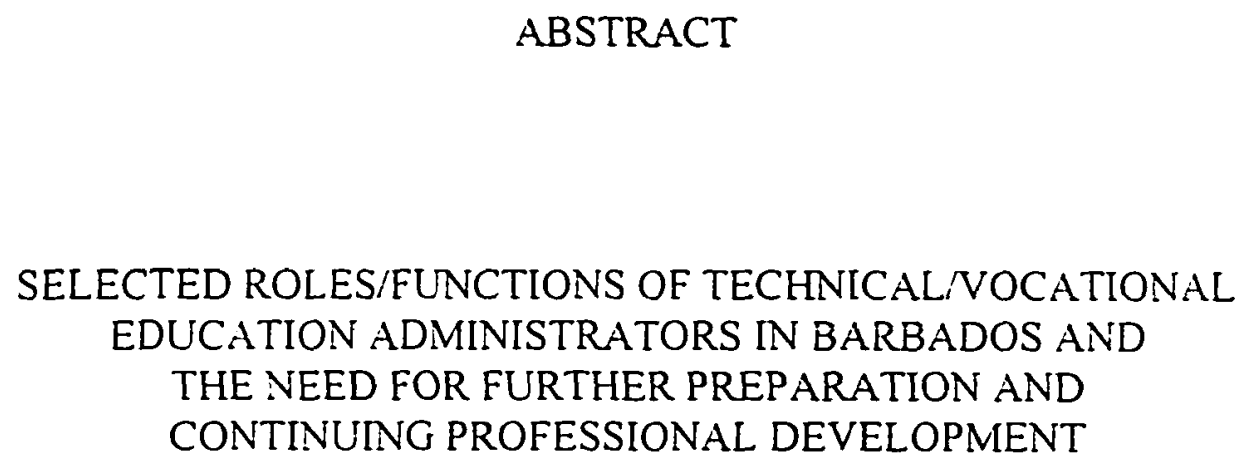

by

Cecil I. Cummins

Chair: Lyndon Furst 


\title{
ABSTRACT OF GRADUATE STUDENT RESEARCH
}

\section{Dissertation}

\author{
Andrews University \\ School of Education
}

\section{Title: SELECTED ROLES/FLNCTIONS OF TECHNICAL/VOCATIONAL EDUCATION ADMINISTRATORS IN BARBADOS AND THE NEED FOR FURTHER PREPARATION AND CONTINUING PROFESSIONAL DEVELOPMENT}

Name of researcher: Cecil I. Cummins

Name and degree of chair: Lyndon Furst. Ed.D.

Date completed: October 1997

The purpose of this study was to identify the roles/functions of technicalivocational education (TVE) administrators in Barbados and to ascertain their personal needs for further preparation and continuing professional development.

The population for the study consisted of 115 TVE administrators from the Ministry of Education, tertiary institutions, vocational centers, Grammar schools, and Newer secondary schools. The survey method was used to gather the data. All respondents were asked to complete a 87 -item questionnaire which described various roles/functions associated with the administration of TVE programs under eight major categories. For each role descriptor, respondents were asked to indicate how important it 
was to their success as a TVE administrator and their need for continuing professional development. The data was analyzed using one-way analysis of variance.

The major findings in the study were:

1. TVE administrators perceived six of eight categories to be very important to their position. School/Community Relations and Business and Financial Management were not considered as being important to their job.

2. While the highest expressed need was in the category of Staff Relations. TVE administrators expressed little need for further preparation in any other category.

3. There were no differences among TVE administrators in the perception of the importance of their roles/functions based on educational background. but those who were permanently employed and appointed in their job attached a higher level of importance to certain roles/functions than those who were of "other" status.

4. TVE administrators who worked in "other" institutions and Newer secondary schools attached a higher level of importance to certain roles/functions than those in Grammar schools.

5. There were no differences among TVE administrators with regard to their perception of their need for further preparation within the eight categories based on tenure in position or educational setting although TVE administrators with less than B.A. degrees expressed a greater need for further preparation than TVE administrators with B.A. degrees or graduate degrees. 
To my father. the late Mortimer Cummins. who made it possible for me to begin my educational journey and who strongly believed that Christian education was the key to success: My brother.

Murlyn Cummins (deceased), who was so close to me: My mentor. Ferris O. Scott. tor her interest. dedication. scholarship. and examplary life as a Christian educator. who provided the inspiration for the attainment of this goal; To my dear wife. Annette. and sons. Ryan. Neil and Shane, who reluctantly relinquished their right to my presence and support and endured with me the period of necessary separation in order to complete this dissertation. Their support was unfailing and persevering. 


\section{TABLE OF CONTENTS}

LIST OF TABLES $\ldots \ldots \ldots \ldots \ldots \ldots \ldots \ldots \ldots \ldots \ldots \ldots \ldots \ldots \ldots \ldots \ldots$

ACKNOWLEDGMENTS $\ldots \ldots \ldots \ldots \ldots \ldots \ldots \ldots \ldots \ldots \ldots \ldots \ldots \ldots \ldots \ldots \ldots$

Chapter

I. INTRODUCTION $\ldots \ldots \ldots \ldots \ldots \ldots \ldots \ldots \ldots \ldots \ldots \ldots \ldots$ I

Background of the Problem ................... 1

Statement of the Problem .................... 12

Purpose of the Study $\ldots \ldots \ldots \ldots \ldots \ldots \ldots \ldots \ldots \ldots \ldots \ldots$

Research Questions ....................... 14

Significance of the Study ....................... I4

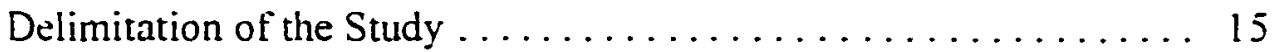

Basic Assumptions . . . . . . . . . . . . . . . . . . 15

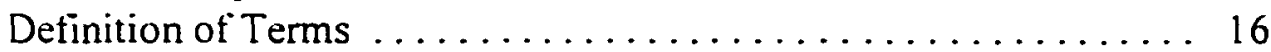

Organization of the Study $\ldots \ldots \ldots \ldots \ldots \ldots \ldots \ldots \ldots \ldots$

Summary $\ldots \ldots \ldots \ldots \ldots \ldots \ldots \ldots \ldots \ldots \ldots \ldots \ldots \ldots \ldots$

II. REVIEW OF LITERATURE $\ldots \ldots \ldots \ldots \ldots \ldots \ldots \ldots \ldots \ldots \ldots \ldots \ldots$

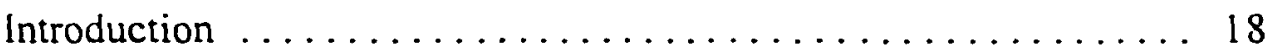

Leadership Studies . . . . . . . . . . . . . . . . . . 19

Leadership Development and Professional Development ....... 22

Leadership in Educational Administration ............ 29

Leadership in Technical/Vocational Education Administration ... 31

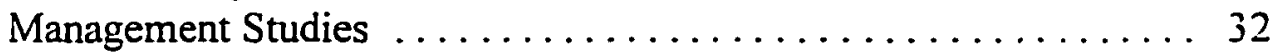

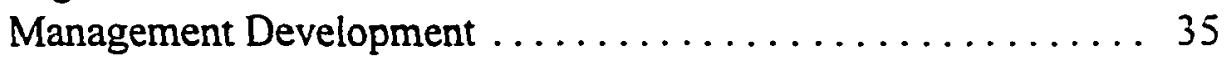

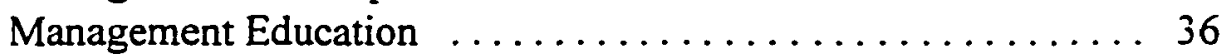

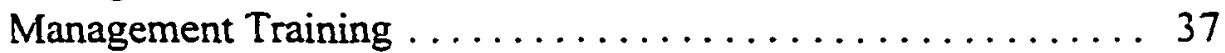

Leadership and Management in Organizations .......... 37

Issues in Technical/Vocational Education . . . . . . . . . . 38

Future Challenges in Technical/Vocational Education ........ 39

Integration of General and Vocational Education . . . . . . . . . 40

Related Studies in Leadership Roles and Professional Development . 41

iv 


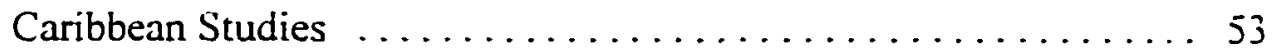

Summary . . . . . . . . . . . . . . . . . . . . . . 55

III. METHODOLOGY .......................... 57

Introduction $\ldots \ldots \ldots \ldots \ldots \ldots \ldots \ldots \ldots \ldots \ldots \ldots \ldots \ldots$

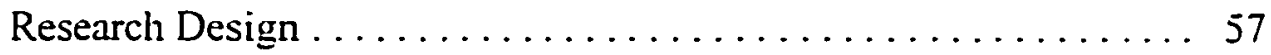

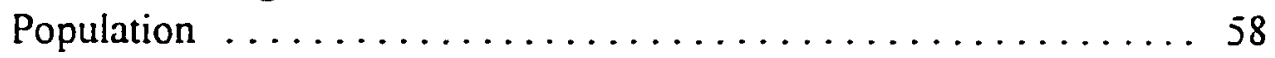

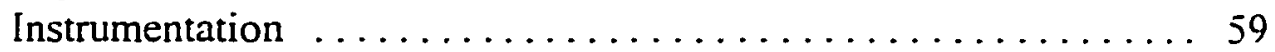

Data Collection Procedure .................... 61

Research Questions and Hypotheses ................. 63

Research Questions .........................63 63

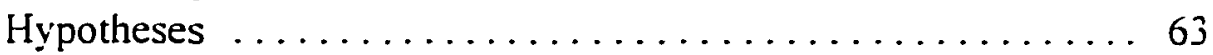

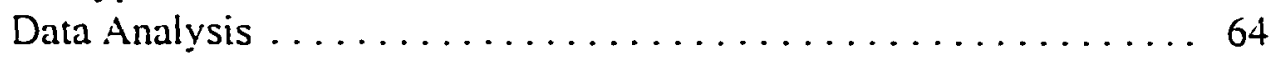

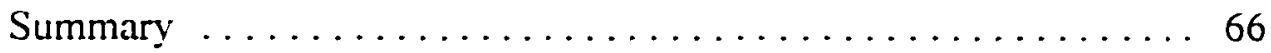

IV. PRESENTATION AND ANALYSIS OF DATA $\ldots \ldots \ldots \ldots \ldots \ldots 6$

Results From Research Questions ................ 71

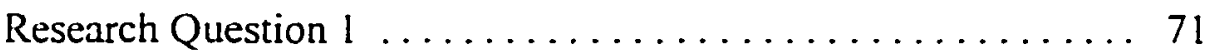

Research Question $2 \ldots \ldots \ldots \ldots \ldots \ldots \ldots \ldots \ldots \ldots$

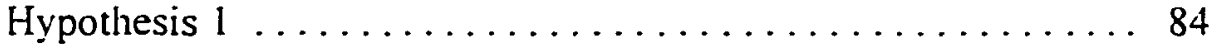

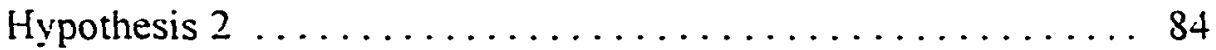

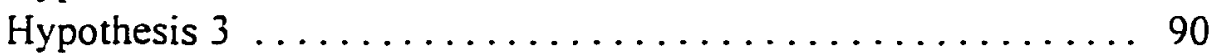

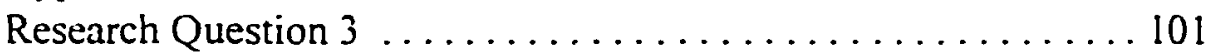

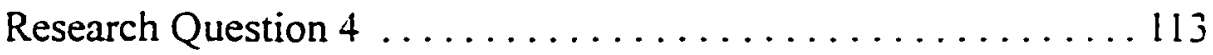

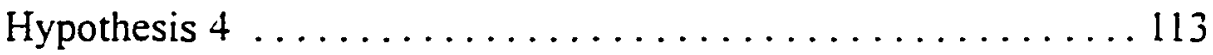

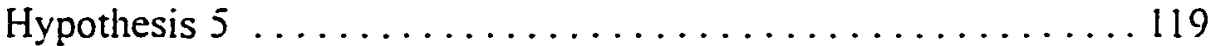

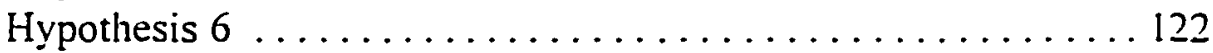

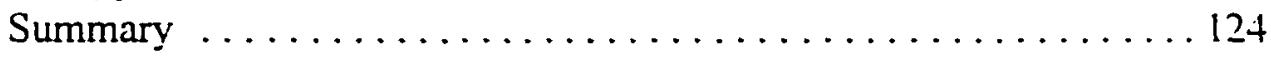

V. SUMMARY, CONCLUSIONS, AND RECOMMENDATIONS $\ldots \ldots 127$

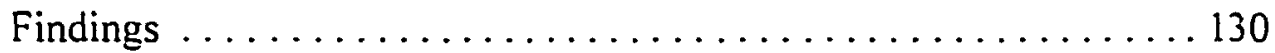

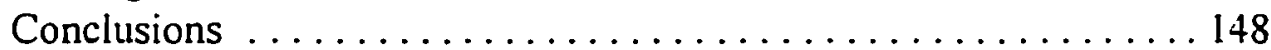

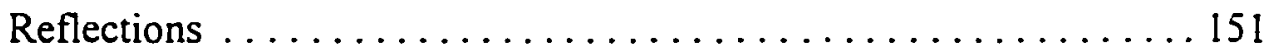

Recommendations .......................... 154

Appendix

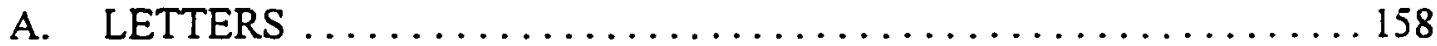

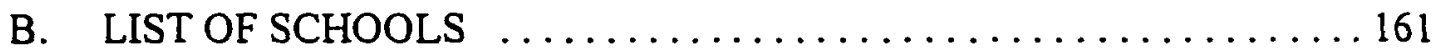

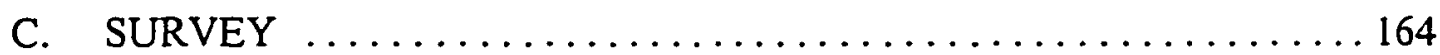




\section{LIST OF TABLES}

1. Technical and Vocational Educational Curriculum $\ldots \ldots \ldots \ldots \ldots \ldots \ldots$

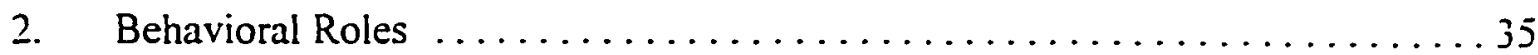

3. Demographic Characteristics: Gender $\ldots \ldots \ldots \ldots \ldots \ldots \ldots \ldots$

4. Demographic Characteristics: Age $\ldots \ldots \ldots \ldots \ldots \ldots \ldots \ldots \ldots . \ldots 6$

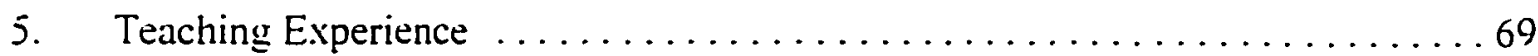

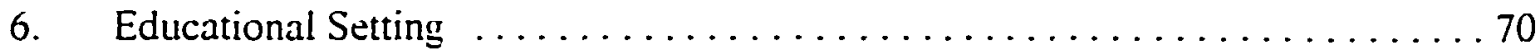

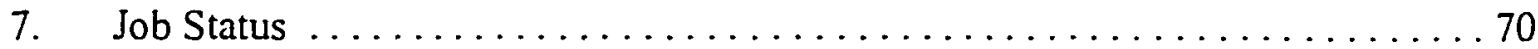

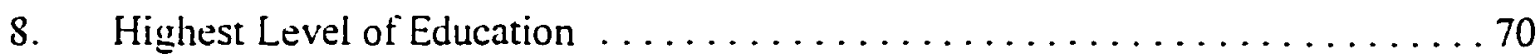

9. Program Focus. Undergraduate $\ldots \ldots \ldots \ldots \ldots \ldots \ldots \ldots \ldots \ldots \ldots \ldots \ldots \ldots \ldots$

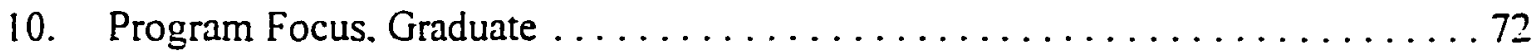

11. TVE Administrators` Perception of the Importance of Roles/Functions by Major Categories . . . . . . . . . . . . . . . . . 73

12. TVE Administrators Perception of the Importance of Program Planning, Development. and Evaluation $\ldots \ldots \ldots \ldots \ldots \ldots \ldots \ldots$

13. TVE Administrators Perception of the Importance of Instructional Management ..........................

14. TVE Administrators' Perception of the Importance of Personnel

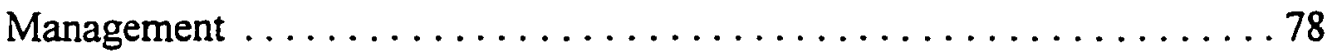

15. TVE Administrators' Perception of the Importance of Staff

Development .............................. 78

vii 
16. TVE Administrators Perception of the Importance of Professional Relations and Self-Development .................. 80

17. TVE Administrators Perception of the Importance of School/ Community Relations ....................... 8 I

18. TVE Administrators Perception of the Importance of Facilities and Equipment Management $\ldots \ldots \ldots \ldots \ldots \ldots \ldots \ldots 2$

19. TVE Administrators Perception of the Importance of Business and Financial Management .................. 83

20. ANOVA for Educational Background and TVE Administrators

Perceived Importance of Roles/Functions by Major Categories $\ldots \ldots \ldots 85$

21. ANOVA for Tenure in Position and TVE Administrators Perceived Importance of Roles/Functions by Major Categories . . . . . . . . 87

22. ANOVA of Items in Category Instructional Management $\ldots \ldots \ldots \ldots \ldots$

23. ANOVA of Items in Category School/Community Relations $\ldots \ldots \ldots \ldots . .90$

24. ANOVA of ltems in Category Facilities and Equipment $\ldots \ldots \ldots \ldots \ldots$.

25. ANOVA of Items in Category Business and Financial Management ....... 91

26. ANOVA for Educational Setting and TVE Administrators" Perceived Importance of Roles/Functions by Major Categories . . . . . . . . 93

27. ANOVA of Items in Category Instructional Management $\ldots \ldots \ldots \ldots \ldots . . \ldots 5$

28. ANOVA of Items in Category Personnel Management $\ldots \ldots \ldots \ldots \ldots \ldots 96$

29. ANOVA of Items in Category Staff Development . . . . . . . . . . 97

30. ANOVA of Items in Category School/Community Relations $\ldots \ldots \ldots \ldots . \ldots 7$

31. ANOVA of Items in Category Facilities and Equipment $\ldots \ldots \ldots \ldots \ldots$

32. ANOVA of Items in Categories Program Planning, Development, and Evaluation; Professional Relations and Self-Development, and Business and Financial Management ............... 100 
33. TVE Administrators Perception of Their Personal Need for Further Preparation in Roles/Functions by Major Categories

34. TVE Administrators Perception of Their Personal Need for Further Preparation in Category Program Planning. Development. and Evaluation

35. TVE Administrators ${ }^{*}$ Perception of Their Personal Need for Further Preparation in Category Instructional Management 106

36. TVE Administrators ${ }^{\circ}$ Perception of Their Personal Need for Further Preparation in Category Personnel Management .

37. TVE Administrators ${ }^{\circ}$ Perception of Their Personal Need for Further Preparation in Category Staff Development 108

38. TVE Administrators Perception of Their Personal Need for Further Preparation in Category Professional Relations and Self-Development

39. TVE Administrators` Perception of Their Personal Need for Further Preparation in Category School/ Community Relations.

40. TVE Administrators` Perception of Their Personal Need for Further Preparation in Category Facilities and Equipment

41. TVE Adiministrators` Perception of Their Personal Need for Further Preparation in Category Business and Financial Management

42. ANOVA for Educational Background and TVE Administrators' Perceived Need for Professional Development by Major Categories ......... . 115

43. ANOVA of Items in Category Program Planning. Development, and Evaluation . . . . . . . . . . . . . . . . 117

44. ANOVA of Items in Category Instructional Management $\ldots \ldots \ldots \ldots \ldots 18$

45. ANOVA of Items in Categories Professional Relations and Self-Development; School/Community Relations; Facilities and Equipment; and Business and Financial Management

ix 
46. ANOVA for Tenure in Position and TVE Administrators Perceived Need for Protessional Development by Major Categories . . . . . . . . 121

47. ANOVA of Items in Categories Program Planning. Development. and Evaluation: and Instructional Management

48. ANOVA for Educational Setting and TVE Administrators

Perceived Need tor Professional Development by Major Categories

49. ANOVA of Items in Category Instructional Management 124 


\section{ACKNOWLEDGMENTS}

I would like to acknowledge the support. scholarly expertise. and essential assistance of my doctoral committee chairnman and dissertation adviser. Dr. Lyndon Furst. who worked to ensure the completion of this dissertation. His constant encouragement. guidance. and support. and. indeed. the astute way in which he used the red ink pen will always be remembered and cherished. I would like to extend my sincere appreciation for the guidance. interest, suggestions. and confidence of the other members of the committee:

1. Dr. Gerald Coy. whose technical proticiency, professionalism. and quiet confidence provided hope and assurance to me;

2. Dr. Newton Hoilette. who has been a friend. counselor. confidant. and a tower of support to me throughout this journey;

3. Dr. Greg Gerard, for his support during the initial stages.

In a special way I am very much indebted to the following persons:

1. Dr. Jerome Thayer, for his open-door policy towards me and whose counsel and statistical advice were invaluable;

2. Dr. Jimmy Kijai, who noticed my statistical bewilderment and cared enough to expend time and energy to rescue me--I am eternally indebted to him:

3. All technical/vocational education administrators who graciously volunteered to xi 
provide the information upon which the analysis of this dissertation is based:

4. Verla Campbell. Renee Skeete. and Loma Thomas who assisted with typing. editing. and formatting this dissertation:

5. Dr. Carlisle Applewhaite whose presence. counsel. and advice meant so much to me especially at times of high frustration:

6. Carlton Campbell and family for providing a home away from home for me. and whose assured support was always evident.

Words cannot express the appreciation and gratitude that I have for my wife. Annette. for her strong support and continued encouragement in the process of completing this research. Her love. confidence, consideration. and understanding were instrumental in making this degree a reality. I also owe special thanks to my sons. Ryan. Neil. and Shane. for their kind support. ready acceptance. and understanding of my absence. Thanks also to my mother. for her quiet confidence and support. as well as oiher members of my family.

To all those wonderful people I express my grateful thanks. To God be the Glory. 


\section{CHAPTER I}

\section{INTRODUCTION}

\section{Background of the Problem}

Barbados has shared a colonial heritage similar to that of its neighboring Caribbean Islands. It experienced British political. economic. and educational domirance for over 300 years until it attained nationhood when it gained political independence from Britain in 1966. Consequently. Barbados inherited the British educational system. which was developed after the European classical tradition (Brathwaite. 1958). Early 20 century reports on education in the British West Indies supported Brathwaite's opinion on the nature of such education and further commented that. in practice. it was the "preserve of those who could afford it and was valued by fee paying families who saw it as a passport to white-collar occupation and a recognized social status" (Gordon, 1968, p. 34).

In these plantation economies (Beckford. 1972), education did not reflect national needs. thereby contributing to underdevelopment. Beckford stated: "For the most part what education became available was irrelevant to the need of a dynamic society.... The content is heavily weighted to the supply of administrative (clerical) skills with little or no emphasis on technical and managerial skills" (p. 208).

The above view was also supported by the Barbados government in the Development Plan, 1973-1977, which stated: "When Barbados was a mono-crop 
economy. the only skills in demand were those of the merchant. planter. doctor. lawyer. teacher and administrator. Consequently the educational system was an elitist one geared to producing, out of many, a few academic students needed for university training" (Barbados Office of Ministry of Economic Affairs. 1993. p. 10: hereafter referred to as BOMEA).

The lew academics referred to above were a mere $2 \%-3 \%$ who could master the inherited curricula (Bacchus. 1980). This situation demanded a curricula that met the needs of the vast numbers of school-leavers and leadership skills to ensure that it be successfully implemented.

According to Gordon (1968). British authorities in the West Indies doubted whether the bookish. verbal. and classical-oriented studies leading to the Cambridge examinations were the best preparation for the developmental needs of the West Indies Colonies. He also noted that comments of a similar nature were penned in the Trinidad Education Report of 1916 (p. 34), and that of Gray in British Guiana in 1925 (p. 35). The Trinidad Report advocated alternatives to classical studies and called for the introduction of bookkeeping. shorthand. and typing. It also recommended administrative reform.

A major breakthrough came from The Marriott-Mayhew Report in the 1930s (Gordon, 1968), which introduced entirely new ideas on secondary education and recommended the introduction of the "Secondary Modern School." It called for a curriculum that was practical in nature to be accompanied by: "a cultural basis of general education directed essentially to the stimulation of interest in the pupils' social and 
industrial. agricultural and commercial pursuits or for social service in Primary school or elsewhere“ (p. 36).

Gordon (1968) further observed that the Marriott-Mayhew Report and the Moyne Report 1939 were controversial. and that they were not readily received. They recorded "a good deal of local opposition“ as it was widely felt that the Secondary Modern School was a threat to the traditional school and would result in the lowering of educational standards (p. 37). B. A. Miller (1985), in an examination of earlier reports on education in the Caribbean. also referred to the Marriott-Mayhew report. She termed it "Modern" as it presented secondary education and vocational training in relation to the economic. industrial. and professional conditions and needs (B. A. Miller, 1985).

Barbados has progressed from an agrarian society to a manufacturing and service-oriented economy, with the tourism sector the major plank on which the economy is built. The government in noting this evolution stated:

With the growth of tourism and manufacturing and the changing nature of agriculture. there is now a demand for a more egalitarian and functional system which can in addition to administrators and teachers produce engineers, artisans. managers, architects, accountants, surveyors and a variety of other technical and professional personnel. Educational planning must, therefore take place within the context of national development and be geared to respond rapidly to the changing structure of the economy. (BOMEA, 1973, p. 10)

Politicians, educational planners, curriculum specialists, social commentators, and those concerned with education in the Third World nations are becoming increasingly aware that investment in traditional education as inherited from colonial masters does not yield the anticipated or long-term results. A developing Third World country, such as 
Barbados. does not have available to it the resources to provide the education required to meet the 2lst century.

Many countries worldwide have experienced a downturn in their economies and indeed Barbados did not escape this development. In a country where 21\% (BOMEA. 1973) of total budget expenditure had been previously allocated to the educational sector. one can imagine the limitations these economic stringencies would have placed on educational development as financial resources became relatively scarce.

The Barbados government was cognizant of this situation and made the following statement:

Persistent negative economic growth, starting during the first quarter of 1990 . and the stabilization program of 1991/92. have greatly contributed to the limited achievement of some of the most important goals and objectives. These circumstances led to the imposition of budgetary restraints on the education sector. (BOMEA. 1993, p. 55)

Historically. the social services, which includes education. appeared to be the foremost casualties whenever countries experienced economic difficulties. This development prompted a leading Barbadian politician. and formerly the Minister of Education. Honorable Billie Miller. to remark: "The struggle then as now was between economy and efficiency and the same contestant always seem to win" ( B. A. Miller. 1985, p. x).

These economic circumstances have impacted heavily on policy makers and professional educators who are currently confronted with many difficult problems. Examples include providing students with relevant job-entry skills, designing instruction for career development, and responding to the needs of less privileged students and 
keeping pace with social. economic. and technological developments. These concerns have tended to place technical and vocational education in a more prominent role. in meeting the needs of young people in a world of work as well as meeting the national objectives.

It must be observed that such developments will place in focus the type of leadership as demonstrated by technical/vocational administrators in Barbados. This is especially crucial as government has determined that the educational system be as efficiently managed as possible (BOMEA. 1973). The document states: "This will require the recruitment of competent and able persons in the administration, in the reorganization and expansion of staff and the constant search for innovative techniques to ensure maximum efficiency“ (p. 10).

Despite these limitations. a measure of success has been achieved in educational development since the 1970s. but it is still inadequate to meet current needs. B. A. Miller (1985) noted that there is an on-going need for para-professionals at all levels and management skills are in scarce supply. She further made the point that traditional education was deficient in two respects: its tools and its style of thinking.

In response to these concerns, the government of Barbados, through the Ministry of Education, has introduced vocational education in all public secondary schools in Barbados to certificate level. Prior to this, education had followed a traditional English format with heavy emphasis on academic subjects. Williams (1968), writing about education in the British West Indies, reinforced this opinion when he stated:

Secondary education in the colonies had been copied from the 19th century models in Europe and the United States but have not kept in pace with the 
originals. Post primary was limited to one kind of school: the academic. college preparatory type. pointing towards the clerical officials and professional calling. ... Such people develop a stigma for manual labor. which already has to struggle against the stigma impressed upon it. by long association in many colonies with slavery. (p. 12)

Thus this academic-type education. which was also known as general education. has continued but the curriculum has been expanded to include a listing of technical education subjects. Through a series of options. students can select a number of subjects including woodwork. metalwork, technical drawing. home economics. and arts and craft. For the purpose of this study. the current subjects that comprised the technical/vocational education curriculum as practiced in Barbados are presented in Table 1.

This study program was not geared to the impartation of specific job skills but its thrust was to provide a sound general education (classical education) (Barbados Office of Ministry of Education and Culture. 1993; hereafter referred to as Barbados Ministry of Education). This statement seemed to confirm public opinion as it is increasingly being observed that school leavers are ill-equipped for the world of work and that the curriculum must address this need by ensuring that school-leavers possess marketable job skills.

Francis et al. (1994) reported:

In the first two and sometimes three years at secondary school, students are exposed to a curriculum comprising of academic and TVET subjects. At the end of the third year, each student makes choices and starts to specialize, thus it will be seen that the bulk of the specialization begins at fourth year continuing to the fifth year. At this level students prepare and take the examinations that are offered by the various examinations bodies. (p. 3) 
These examination bodies are Caribbean Examination Council (CXC). University of Cambridge. University of London. Pitman Examination Institute. and The London Chamber of Commerce.

TABLE 1

TECHNICAL AND VOCATIONAL EDUCATION CURRICULUM

\begin{tabular}{llll}
\hline $\begin{array}{l}\text { INDUSTRIAL } \\
\text { ARTS }\end{array}$ & $\begin{array}{l}\text { HOME } \\
\text { ECONOMICS }\end{array}$ & $\begin{array}{l}\text { BUSINESS } \\
\text { STUDIES }\end{array}$ & $\begin{array}{l}\text { ARTS AND } \\
\text { CRAFT }\end{array}$ \\
\hline $\begin{array}{l}\text { Building } \\
\text { Technology }\end{array}$ & Home Management & $\begin{array}{l}\text { Principles of } \\
\text { Business }\end{array}$ & Art \\
Woods & Food and Nutrition & $\begin{array}{l}\text { Principles of } \\
\text { Accounts }\end{array}$ & $\begin{array}{l}\text { Arts and } \\
\text { Craft }\end{array}$ \\
$\begin{array}{l}\text { Mechanical } \\
\text { Engineering }\end{array}$ & Clothing and Textiles & Typing & Ceramics \\
$\begin{array}{l}\text { Electrical } \\
\text { Technology }\end{array}$ & Shorthand & Jewelry \\
$\begin{array}{l}\text { Craft Design and } \\
\text { Technology } \\
\text { Technical Drawing }\end{array}$ & & Information & Technology \\
\hline
\end{tabular}

The tertiary-level institutions in Barbados are: (1) Barbados Community College. (2) Erdiston Teachers' Training College, (3) The Samuel Jackman Prescod Polytechnic. and (4) The University of The West Indies. All are involved in the preparation and delivery of Technical Vocation Education Training. Their role is dual, for coupled with the need to have up-to-date preparation programs for aspiring technical education 
administrators is the need to determine continuing professional development areas for practicing administrators.

\section{The Barbados Community College}

Barbados Community College. a tertiary institution. was established in 1969. It has developed a 2-year Associate Degree in limited areas of TVET. It has collaborated with Erdiston Teachers' Training College in the delivery of training in technical/vocational subjects.

Government officials have lamented the limited progress made in developing a technical and vocational training program and also the failure of the institution to achieve a balance between academic and vocational education (BOMEA. 1988).

\section{Erdiston Teachers' Training College}

Erdiston Teachers' Training College has offered a 2-year training course for nongraduate secondary-school teachers. At this level, teachers received training in Business Education, Home Economics, and Industrial Arts. The Home Economics program was delivered in conjunction with the Samuel Jackman Prescod Polytechnic, while Erdiston, Barbados Community College, and the Polytechnic collaborated in the delivery of the Industrial Arts program. Final assessment and certification of the teachers in these programs were undertaken by the University of The West Indies through the Faculty of Education (Barbados Ministry of Education, 1993). The document stated in part:

As we look forward to the twenty-first century, a revised mandate has been given to Erdiston Teachers' Training College to retrain teachers at both the Primary and Secondary levels. It is anticipated that this new thrust will provide professionals with the opportunity to upgrade their skills in: a. Educational innovations and new 
curricula. b. Testing and measurement. c. Teacher professional development and d. Educational administration. (Barbados Ministry of Education. 1993, p. 6)

\section{The Samuel Jackman Prescod Polytechnic}

The Samuel Jackman Prescod Polytechnic's function has been to collaborate with The Erdiston Teacher's Training College in the preparation of technical/vocational achers for the secondary schools in Barbados.

\section{The University of the West Indies}

The University of the West Indies. Faculty of Education, located in Barbados. through its in-service section has provided Diploma education training for graduate teachers in secondary schools. Four types of teacher-training programs are offered:

1. The I-year In-service Diploma in Education course is aimed at equipping secondary graduate teachers to specialize in the teaching of individual subjects.

2. A 1-year Certificate in Educational Management is offered and targeted at Head teachers, Deputy Head teachers. Senior teachers, Heads of Departments. Education Officers, and other teachers who demonstrated the potential to become school and educational administrators.

3. A Bachelor of Education Degree Program, with specialized options, which includes Educational Administration, is offered.

4. Finally, the faculty has mounted a series of seminars (workshops) focused on specific areas of need. It must be noted that there are no undergraduate or graduate programs in TVET offered at this institution. 
In conducting oral interviews with technical education administrators. one sensed the degree of frustration they experienced. especially at the lack of training opportunities and desired possibilities for advancement. In a study prepared for the United Nations Educational. Scientific. and Cultural Organization (UNESCO) under the aegis of the Ministry of Education in Barbados. the working group reported:

Initial training is provided for Technical Vocational teachers. but unlike their colleagues. in the regular academic subjects. they cannot obtain degrees locally. A number of them therefore leave their discipline to pursue a degree in regular subjects in pursuit of improved status, salary and promotion. (Barbados Ministry of Education. 1993.p. 13)

The above-mentioned situation as reported is an accurate representation of the situation as presently exists in Barbados and echoed by technical/vocational teachers. This exodus has resulted in the loss of potential technical/vocational administrators from the system as they pursue alternative career paths that they consider more rewarding. Goodridge (1985) commented: "Our first task must be to find effective ways of identifying persons who have the qualities of intellect and personality. personal and professional commitment, and capacity for further professional development“ (p. 88).

Campbell and Gregg (1957) expressed a pertinent view on this issue and its relevance to national and technological development. They stated:

One of the indispensable ingredients of a technological society is trained manpower. Technological progress stalls in the face of shortage of trained personnel. Consequently, nations which have advanced most rapidly in technology have found it necessary to accompany this progress with extended educational programs. (p. 56)

Errol Miller (1985), in addressing the issue of the training of educational administrators in the Commonwealth Caribbean, makes the point that one of the 
unwritten qualifications for an educational administrator in the Caribbean is that one must have had a number of years" teaching experience. He is also of the opinion that administrators are usually prepared for their responsibilities informally through a system of in-service apprenticeships. Thus one is able to become an educational administrator without having received professional training as a teacher or as an administrator as promotion is obtained based on one's years of teaching experience.

E. Miller (1985) further highlights the point that the Caribbean has not yet moved to the position where a pool of personnel trained in administration is created within the system and then the various opportunities arise for them to be promoted to administrative posts. He further observed. that at present, "this pattern of preparation for administration is strongly biased in favor of the administrator continuing and perpetuating the Status Quo" (p. 38).

Governments in the Caribbean have become increasingly aware of the need for training administrators. The Barbados government has turned to international. regional. and local agencies for assistance in this regard. Among these are the following: UNESCO, The Commonwealth Secretariat, The University Council for Educational Administration. The Commonwealth Council for Education Administration, University of the West Indies, and the Caribbean Council of Educational Administrators (CARCEA). The need to develop the administrative skills of educational administrators has been foremost in the planning of the Ministry of Education. This is reflected in the following statement: "The Ministry of Education will undertake a number of reforms 
measures in its central administration which are designed to improve the planning and management of the education and the training sector" (BOMEA. 1993.p. 6).

Jenkins (1991) addressed this issue of school leadership/administration and contended that it was time to adopt a new leadership approach to create effective ideas about organization. He argued that traditional models of leadership that were characterized by words as systems. accountability. control. status. and hierarchy were not as useful as they once were for satisfying social and national demands on schools.

Indeed, this call should be the focal point of technical/vocational education administrators in Barbados as they examine the need for further preparation and continuing professional development.

\section{Statement of the Problem}

In the Barbados government's development plan for education from the 1960s to the present. 1993-2000. the dominant theme--the lack of administrative skill in the delivery of technical/vocational education training--was continually highlighted. In the 1993-2000 plan and under the caption "Issues in TVET (Technical Vocational Education Training) Programs" the deficiencies were forcibly and comprehensively illustrated. The document stated:

TVET programs are deficient in quality of instruction, amount of instructional material and type of curriculum. Quality instruction is weakened by the fact that teacher training programs are linked to basic levels and there is no appraisal/feedback system. ... In addition curriculum weaknesses are evidenced in absence of staff training, inappropriate accreditation standards and lack of mechanisms for conducting rigorous program reviews. Instructional capabilities are weak in key areas of educational planning and research, curriculum development, financial management, information technology and testing and management. (BOMEA, p. 57) 
Some initiatives have emerged that aimed at emphasizing the integration of academic and vocational education. and providing greater opportunities for "less academically" inclined students. Attention is being focused on developing competencybased evaluation for technical/vocational programs and also on organizing and implementing school-to-work transition programs. In view of these developments. it was necessary for criteria to be established for the determination of roles/functions of technical/vocational education leaders in Barbados. Second. it was necessary that upportunities be made available to facilitate continuing professional development programs and activities for practicing administrators.

To date. a study has not been conducted to determine the competencies required by technical/vocational education administrators in Barbados, nor has information been collected on their continuing professional development needs.

\section{Purpose of the Study}

The primary purpose of the study was to collect and analyze data to identify the roles/functions of technical/vocational education administrators in Barbados and to identify their personal needs for further education and continuing professional development.

In addition, the study addresses the differences between survey respondents according to their educational background, tenure in position, and educational setting. 


\section{Research Questions}

The tollowing research questions are addressed in this study.

1. What do technical/vocational education administrators perceive to be the importance of each of the selected roles/functions?

2. What differences exist among technical/vocational education administrators regarding their perceptions about administrator roles/functions. comparing the variables of educational background. tenure in position. and educational setting?

3. What do technical/vocational education administrators perceive to be their degree of need for further preparation and continuing professional development in each selected role/function?

4. What differences exist among technical/vocational education administrators regarding their professional development needs, comparing the variables of educational background. tenure in position. and educational setting?

\section{Significance of the Study}

It is anticipated that the findings and analysis from the study will be useful in highlighting training and development needs among technical/vocational education administrators. It is hoped that it will also identify the roles/functions of administrators and thus increase the awareness of individuals who are responsible for the recruitment and selection of technical/vocational education administrators. This study can also be useful in highlighting the need for the development of certification programs at the undergraduate and graduate level. The information can provide indicators to the relevant authorities on the matters that need to be addressed if they are to effect efficiency in the 
absence of necessary resources. If this study can assist in the reduction or even the elimination of the stigma that is attached to technical/vocational education in Barbados. it will have been a worthwhile effort.

\section{Delimitation of the Study}

This study was limited to the population of technical/vocational education administrators in Barbados as employed by and registered with the Ministry of Education. Educational leaders at this level include those protessionals who administer programs of technical/vocational education. These administrators are Ministry of Education officials and principals and heads of departments of The Barbados Community College. Erdiston Teachers' Training College. 22 public secondary schools. and The Samuel Jackman Prescod Polytechnic.

\section{Basic Assumptions}

The following assumptions should be noted:

1. It was assumed that technical/vocational education (TVE) administrators were cognizant of the competencies required to perform their roles/functions as measured by the Norton et al. (1987) instrument.

2. It was assumed that technical/vocational educational (TVE) administrators had a major influence on the educational program of the school.

3. It was also assumed that the population studied provided valid and reliable results. 


\section{Definition of Terms}

The following terms are defined as they are used in this study.

Administrator: The principal. the person responsible for the daily operation of the school. the head of departments. and supervisory officers in the Ministry of Education.

TVE: Technical/vocational education administrators.

Continuing Professional Development: Any planned learning activity provided to individuals for the purpose of improving the performance of such persons: synonymous with in-service education. staff development. or professional development.

Role:Function: A related task or activity to be performed by persons occupying a specified position within an organization.

Secondary School: An institution of learning that caters to students between the ages of 12-16.

TVET: Technical/vocational education and training.

Tertiary Level Education: Post-secondary education.

Technical Education: A blend of general education. vocational skills. and technology.

Vocational Education: Similar to technical education but constitutes more specific occupational or practical skills.

\section{Organization of the Study}

This study consists of five chapters. Chapter I presents the problem. its content. and its background. The chapter also seeks to establish the need for the research by 
presenting the hypotheses to be tested. the scope and delimitations of the study. and the definition of pertinent terms used in the study.

Chapter 2 provides a review of related literature. examines existing studies that bear relevance to the research. and also provides a theoretical and conceptual framework for the study. It examines traditional administrative practice and procedure in the context of the need for change and reform in Barbados and the "developing world."

Chapter 3 examines the research procedure used in the study and its implementation. Chapter 4 highlights and analyzes the data and reports the results of the data analysis. Chapter 5 summarizes the study and presents reflections and recommendations for further research.

\section{Summary}

In this study. I examined the perceptions of technical/vocational education administrators of Barbados in two areas: (1) the range of importance in their job roles/functions. and (2) the needs identified for further preparation and continuing professional development to respond to their job roles/functions. I also gave a brief overview of the current status of technical/vocational education in Barbados as portrayed by the Ministry of Education and other concerned educators. In addition. this chapter highlighted the background of the problem that confronts technical/vocational education administrators in Barbados. 


\section{CHAPTER II}

\section{REVIEW OF LITERATURE}

\section{Introduction}

This study identified the roles/functions of technical/vocational education administrators in Barbados and examined their perceived need for further preparation and continuing professional development. This chapter supports this purpose by reviewing the related literature. Since no study on the roles/functions of technical/vocational education administrators in Barbados has ever been done. the research reviewed here is directly related in terms of technical/vocational education and professional development of administrators in the field but not specific to Barbados. The literature reviewed is divided into the following categories: leadership studies, management studies, issues in vocational education. related studies in leadership roles and professional development. and Caribbean studies.

Schon (1983) is of the opinion that the professions have become essential to the functioning of our society. He draws our attention to the fact that society's principal business is conducted through specially trained professionals. This specialized training is geared to cure disease, to maintain law and order, to manage business and industry, to design and to construct buildings, and to educate our children. Society looks to professionals for the definition and solution of our problems, and it is through them that 
we strive for social progress. The changing nature of our societies demands the rethinking of professional roles. Calls are being made for professionals to set about to improve society. not just service it. to become more socially conscious. to be more of an initiator than a responder (Schein. 1972). In such an existing climate. it becomes necessary to provide leaders who can coordinate the talents and abilities of these professionals so that our society remains healthy, safety is not jeopardized. goods and services are produced, buildings are safe. and our students learn. Concern has been expressed as to what type of leadership is appropriate and whether that leadership is representative of all types of organizations.

\section{Leadership Studies}

Leadership has been described as one of the most observed and studied concepts in the modern world. and yet. according to Campbell (1984), it is also one of the least understood of all social processes. He further observed that leadership seems to have an elusive and mysterious quality about it that makes it easy to recognize, hard to describe. difficult to practice, and almost impossible to create in others on demand.

"Leadership." wrote Yukl (1984). "is a subject that has excited interest among scholars and lay people alike." He continued, "It has challenged Behavioral Scientists over time to discover what traits, abilities, behaviors, source of power, or aspects of the situation determine how well a leader is able to influence followers and achieve the required objectives" (p. 1).

Defining the term "leadership" is not a modern problem, neither is it a simplistic task. Stogdill (1974) concluded that "there are almost as many definitions of leadership 
as there are persons who have attempted to define the concept" (p. 7). Bennis (1984: Bennis \& Nanus. 1985) noted that there are more than 350 definitions for leadership recorded in the literature.

Hemphill and Coons (1957) see leadership as "the behavior of an individual when he is directing the activities of a group toward a shared goal" (p. 7). According to Tannenbaun. Weschler. and Massarik (1961), "leadership is interpersonal influence exercised in a situation and directed through the communication process toward the attainment of a specified goal or goals" (p. 24). Stogdill ( 1974) maintains that leadership is "the initiation and maintenance of structure in expectation and interaction" (p. 14). Hersey and Blanchard (1982) posit the view that leadership is "the process of influencing the activities of an individual or group in efforts toward goal achievement in a given situation. In essence. leadership involves accomplishing goals with and through people" (p. 84). Rauch and Behling (1984) view leadership as "the process of influencing the activities of an organized group toward goal achievement" (p. 17). Tead's (1935) oftenquoted definition reminds us that "leadership is the activity of influencing people to cooperate toward some goal which they come to find desirable" (p. 20). And finally. Jacob and Jaques (1990), state. "Leadership is a process of giving purpose (meaningful direction) to collective effort and causing willing effort to be expended to achieve purpose" (p. 6).

Burns (1978) commented that "no field of study calls for a more difficult and daring crossing of disciplinary borders than does the study of leadership and no field 
suffers more from narrow specialization" (p. vii). Kellerman (1984) concluded that there is profound agreement among the diverse contributors on at least three key points:

1. Leadership has to do with no less significant a matter than how people in groups organize themselves.

2. Leadership is concerned with issues of dominance and deference that are endemic to virtually all living things.

3. Knowing more about leadership will enable us to better understand our past and present and. hopefully. to better manage the future.

Niehouse (1988) jolts us to reality as he pointedly affirmed that "leadership is not a panacea. It will not cure all problems and the ones it can deal with are not cured overnight. Leadership is not wondrous magic--it is a Strategic Skill" (p. 171). Peters (1988) concluded: "We are finally learning that leadership is all about getting people engaged. involved. committed. and excited about a useful vision that is about quality and innovation" (p. 39).

It must be noted that these authors through their definitions of leadership reflect the assumption that leadership is a "social influence" and a "process." In this activity called leadership, influence is exerted by one person over other people in order to achieve a desired result. Leadership, therefore, is not a one-way process but an interactive process where the leader communicates his wishes to his followers who cooperatively respond and participate in achieving the common goal. The success of the organization is highly dependent on the quality of leadership it attracts. 
Bennis (1984) expressed the view that it is the quality of leadership that ultimately determines which organizations prosper and which fail. Quality leadership is crucial to the administration of technical/vocational education in Barbados. The leadership challenge to technical/vocational education administrators will become more demanding as they respond to the changes brought about by technological advances in the society and the range of occupational opportunities that will result from this change. These administrators are well positioned to chart the required path that will accomplish the desired result. Thus with planned education and training, and visionary leadership. the societal objectives can be met as well as the professional development goal of technical/vocational education administrators.

\section{Leadership Development and Professional Development}

Bass and Stogdill (1981) believe that leaders need to perform in a variety of areas. and in order to successfully accomplish the task. leadership development is necessary. These attributes can be tound in leadership behavior in all professional roles. It is expected that. in education, administrators and teachers would possess these attributes.

It is uncertain whether leadership style or development is a conscious or studied decision of leaders or whether the adoption of a style is the natural extension of the personality, beliefs, and value system. Vineyard (1993) expressed the view that it is likely that educational leadership style and development are determined by the interaction of a number of different factors. Among these are: (1) the personal characteristics of the leader himself. (2) the characteristics of the various constituencies internal and external to 
the institution. and (3) the circumstances under which initial leadership is undertaken. and the changing circumstances in which it is continued.

To perform successfully as administrators or teachers. individuals need more than leadership style and attributes. They also need the knowledge and skill attributes that are unique to their given roles. There are distinguishable attributes that determine whether individuals can perform the specific occupational or technical tasks of their professional roles. There are numerous way of acquiring these skills. Bass and Stogdill (1981) attest that real leaders--leaders who teach and are taught by their followers-acquire many of their skills in everyday experience, in on-the-job training. and in dealing with other leaders and followers.

A review of related literature reveals that some of the characteristics. knowledge. and skills common to successful leaders can be significantly influenced by a reasonable amount of continued planned education and training (Bass \& Stogdill. 1981; Lester. 1981: Manz \& Sims. 1986; Yammarino \& Bass, 1988). Thus leadership development is only one part of professional development. Professional development consists of cultivating both the leadership attributes and the attributes that facilitate successful performance in a particular professional role.

Professional development is not a new term or a new phenomenon to educators. It was formerly referred to as in-service education as far back as the 1850 s when teachers received their basic instruction from laymen in the community, to the early 1900 s in the pupil/teacher system (the case in Barbados and indeed the Caribbean), to the middle 1900s when formal programs were geared to help teachers obtain teacher-training 
certificates and. later. college degrees. The first documented distinction between preservice education and in-service education was penned in a major 8-year educational study that began in 1933. involving universities and several school districts (Tyler. 1970).

Many definitions of in-service education have been recorded. Meade (1971) referred to it as "the continued updating of the practitioners in the classroom" (p. 211). Harris (1980) saw it as any planned learning opportunities provided to personnel for purposes of improving the performance of such personnel in already held or assigned positions. Fielding and DelSchalock (1985) regard it as "the deliberate effort to alter the professional practices. beliefs and understandings of school personnel toward an articulated end" (p. 23).

In-service education is often used interchangeably with terms such as staff development. continuing education, and professional development. It is further defined as "any professional development that a person undertakes, singly or with others, after receiving his/her initial teaching certificate and after beginning professional practice" (Edelfelt \& Johnson. 1975. p. 5).

Considerable literature has been written on the continuing professional development of teachers (Cohen, 1981; Lawrence, 1974; Showers, Joyce. \& Bennett 1987, Sparks. 1983: Sparks \& Loucks-Horsley, 1989). The Barbados government is cognizant of this and has repeatedly highlighted the need for professional development of teachers, and in effect, considers it of crucial importance. In a report prepared by the Ministry of Education, the central planning office for education in Barbados, is recorded this statement: "The government has identified and mandated Erdiston Teachers' Training 
College to retrain teachers. It is anticipated that this new thrust will provide professionals with the opportunity to upgrade their skills" (Barbados Oftice of Ministry of Education and Culture. 1993. p. 6). It continued: "The emphasis in this new phase should be on assisting the teacher to function in all departments and emphasize re-training in light of upgrading management skills" (p. 6).

In- service education has not been without its critics. Indictment has been forthcoming from many quarters. "Piecemeal patchwork. haphazard and ineffective" (Edelfelt \& Lawrence. 1975. p. 16) are some of the harsh words used in the description of such programs. Boyer ( 1983 ) pronounced. “Too often. staff development programs have subjected teachers to an occasional day-long workshop conducted by 'experts on leave from .Mt. Olympus.' who were 'long on process. short on substance. and knew little about the classroom" (p. 178). Sparks ( 1987) found that teachers typically regarded their inservice training as useless and a one-time event that had little real influence on their competence.

Despite these apparent limitations. it appears to be one of the fastest growing industries in the business world today, and one may pose the questions: Should continuous in-service education be an integral part of the career of educators? Can inservice education become more effective? Apparently many educators feel that the answer to both questions must be yes (Bottoms, 1975). Bottoms saw in-service education as having at least three purposes: to enable educators to acquire the competencies needed to (1) implement education improvement activities directed towards specified student needs; (2) improve their own or expected goals of professional development, which may 
or may not lead to higher levels of certification. and (3) meet their own goals of personal growth.

In a comprehensive review of research on in-service education by Lawrence (1974), a number of strong patterns of effectiveness emerged. The 97 studies that were analyzed showed that differences in materials. procedures, design. and setting for inservice education are indeed associated with differences in effectiveness. Some of the more important tindings were these:

1. School-based in-service programs concerned with complex teacher behaviors tended to have greater success in accomplishing their objectives than did college-based programs dealing with complex behaviors.

2. Teacher attitudes are more likely to be influenced in school-based than in college-based programs.

3. School-based programs in which teachers participated as helpers to each other and planners of in-service activities tended to have greater success in achieving their objectives than did programs which were conducted by college or other outside personnel with the assistance of teachers.

4. Teachers were more likely to benefit from in-service education activities that were linked to a general effort of the school than they were from "single-shot" programs that were not part of a general staff-development plan.

5. Self-initiated and self-directed training activities were seldom used in inservice education programs, but this pattern was associated with successful accomplishment of program goals. 
Edelfelt and Lawrence (1975) delivered a strong indictment against in-service education when they concluded that it has been the weakest and most haphazard component of teacher education. They also expressed the opinion that in-service education has not been nearly as effective as it might have been considering the expenditure of time. effort. and resources that have been allocated to it.

Consistent with in-service education is the question of certification. Boulding (1972) stated :

Unless there is some distinction between the certified and the uncertified. the incentive to obtain certification is considerably lowered. and if incentive to acquire knowledge and skill is less than the incentive to acquire certification. certification may be the major avenue in society through which a demand for knowledge and skills is encouraged. (pp. 133-134)

In a report of the University Council for Educational Administration (UCEA), it was strongly suggested that the preparation and certification of educational administrators should be increasingly related to well-defined concepts of effective administration and leadership performance. The authors envisaged administrators' performance as a complex phenomenon and recommended that progress be made in clarifying the objectives of administrator performance and in the orienting of selection. recruitment. preparation. and certification in the relevant direction (UCEA, 1973).

The Department of Educational Research and Development, Faculty of Education, University of the West Indies, Cave Hill, is mandated to ensure the quality of teacher training and certification in Barbados and the Eastern Caribbean (Barbados Ministry of Education. 1993). Programs currently being offered are: 
1. A 2-year program as initial training occurs after the student teacher has been teaching for about 3 to 5 years in the system.

2. A l-year Diploma program is offered at the in-service section of the Faculty of Education for university graduates who have been teaching within the system.

3. A wide range of certificate programs is available for professional upgrading of teachers following initial training. A Certificate in Educational Management and Administration is offered.

The minimum qualification for entry to the College is: (1) passes in tour CXC General Proticiency: Grades 1 or 2 or the equivalent. including English: and (2) Diploma in Education (a university degree is required). It should also be noted that:

1. The duration of the initial teacher training for non-graduate teachers is 2 years. while that for unqualified graduate teachers is 1 year.

2. A professional qualification is compulsory for non-graduates to be given a permanent appointment in the public service.

3. At the tertiary level. a vocational teacher's in-service training program is offered and its patrons receive the Teachers' Advanced Professional Certificate.

Since school administrators are held responsible for school outcomes. it would be particularly important to administrators to know what type of leadership style is required to effectively perform their role as technical/vocational education administrators. If schools are to adequately meet the demands of society and educational reformers for excellence, ways must be found to increase the commitment of Caribbean governments and indeed the populace to administrative preparation programs. 


\section{Leadership in Educational Administration}

The literature often considers administration as being different from leadership.

Little (1970) considers administration as having two function: leadership and management. In his context. leadership is viewed as living ahead of the institution. and management is seen as arranging and operating the institution. This opinion is consistent with that expressed by Weber and Weber (1961) who stated:

To refer to educational administration as leadership is to assign it a much more significant role than mere management. It is far too limited a view to conceive of administration in strictly operational terms. Management is an important part of education. but it is only a part: management is not synonymous with leadership. ... Leadership. on the other hand. attaches paramount importance to the progressive development of a school program which is the outgrowth of vital intellectual activity by all those in the community who are concerned with the growth and development of the young. . . Administrators may or may not be responsible for the introduction of new ideas. in fact. in many situations the administrator's leadership role may be that of encouraging others to make contributions to problems. (pp. 73-74)

Cunningham ( 1985 ) raised a number of significant questions about the criteria for meaningful leadership preparation. He noted that in past years "leaders have often simply emerged: they have drifted into positions of leadership or been drafted for leadership roles" (p. 18). Reliance on emergent leadership is not sufficient. More highly organized and deliberate attempts to develop leadership are called for. This concern has led to an examination of present programs and recommended reforms for the future.

Growing concern over the quality of American education found expression in the National Commission on Excellence in Education's $A$ Nation at Risk (1983), which described schools as wallowing in "a rising tide of mediocrity" (p. 24). Among this effort 
to "forcefully repair the sinking ship" (Hawley. 1988. p. +18 ). standards for teacher training and certification were targeted (Wilson \& Rossman. 1993).

At the Purdue Conference (1971). the participants formulated a series of assumptions fundamental to preparation programs in educational leadership (National Association of Secondary School Principals [NASSP]. 1975). These were:

1. School administrators are accountable for educational leadership.

2. The development of educational leadership requires a continuous progress program.

3. The tirst step is to identify and incorporate the existing competencies of a trainee upon entry.

4. Further progress is determined by the achievement of the program requirements rather than time requirements.

Administrative practice must be based on competence. Bennis (1984) interviewed 90 outstanding leaders and their subordinates with the intention of learning what made real leaders. as opposed to effective managers. "tick." After 5 years of research. he identified four comperencies which he considered to be common to the 90 leaders. Bennis listed these competencies as: (1) management of attention; (2) management of meaning: (3) management of trust: and (4) management of self. He made the point that leadership is felt throughout any organization and that it gave pace and energy to the work and empowered the workforce.

Leadership and management do not occur absent context. Effective managing and leading any organization require daily interaction with a large number of groups and 
individuals. One may think of good management as the systematic application of an array of skills to provide for an orderly and efficient school system.

\section{Leadership in Technical/Vocational \\ Education Administration}

Technical/vocational education requires effective and assertive leadership at both the secondary and post-secondary level. To provide the kind of competent leadership needed. the person selected as supervisor and administrator of these programs must be adequately prepared on both a pre-service and in-service education basis. The development of high-quality pre-service and in-service education programs requires knowing what competencies these leaders must acquire to be successful in their various roles.

Wenrich and Wenrich (1974) believe that persons in leadership positions should have high performance aspirations for the organization if they are to be effective. They also are of the opinion that there should be a leadership shift from central offices to local technical/vocational education leaders who have the competence to plan. operate. and evaluate vocational programs on the secondary and post-secondary level. In Barbados. however. not only do we need more leaders for administrative roles. we need a "new breed" of leaders/persons who have conceptual, technical, administrative, and human relation skills needed to develop dynamic technical/vocational education programs which will serve the needs of individuals and society in Barbados. 


\section{Management Studies}

Management is a difficult term to describe. It has a variety of applications and interpretations--all correct within a given set of parameters. Sometimes it is used to describe the executives and administrators of an organization; in other cases, it suggests the professional career path aspired to by most business administration students, and in still other cases it refers to a system of getting things done.

Dunham and Pierce (1989) defined management as "the process of planning, organizing, directing, and controlling organizational resources (human, financial, physical, and informational, in the pursuit of organizational goals)." This process necessitates the use of people and other resources to accomplish its objectives. Barnard (1962), Drucker (1986), and Massie (1971) agreed that the term management refers to a common set of activities that are designed to promote and direct purposeful work. They further affirmed that whenever people deliberately influence their own action or the action of others, they are managing. In their opinion, management, as a specific set of organizational activities that constitutes an occupation, occurs when a number of people have joined together to accomplish some task or goal. In general usage, the word management identifies a special group of people whose job it is to direct effort toward common objectives through the activities of other people. All organizations require managing.

Harbison and Myers (1959) offer a threefold concept for management. They observe management as (1) an economic resource, (2) a system of authority, and (3) a class or elite (pp. 21-86). 
Drucker ( 1986 ) informs us that management arose in the large business enterprises of the 1870 s. but by now it is clear that management pertains to every single social institution. Management includes a variety of occupations. each of which involves different responsibilities. skills. attitudes. and values. Schein (1984) noted that "management" is a catch-all phrase used to depict such diverse positions as supervisor. functional manager. general manager. entrepreneur. and chief executive officer (CEO). Massie (1971) expressed the view that the study of management has evolved into more than the use of means to accomplish given ends. Today it includes moral and ethical questions concerning the selection of the right ends toward which managers should strive (p. +).

Drucker (1986) believes that modern society has evolved and has become a society of organizations. The overwhelming majority of all people in developed societies are employees of an organization. Each of these organizations. in turn. depends for its functioning on management. which is the effective. integrating. life-giving organ of the organization (Barnard. 1962). He further observed that managerial functions are essentially the same regardless of the type of organization or the level of the managers in the organization. Organizations are also referred to as a collection of people working in a division of labor to achieve a common purpose. These writers seem to imply that organizations exist because people are limited in their physical and mental capabilities and thus need organizations to perform work tasks that are beyond their individual capabilities. Massie (197l) contends that although different authorities offer different names for the key functions of management, there is general agreement on most of the 
actual functions of a manager. He described the seven functions in the job of management as:

1. Decision making--the process by which a course of action is consciously chosen from available alternatives for the purpose of achieving a desired result.

2. Organizing--the process by which the structure and allocation of jobs is determined.

3. Staffing--the process by which managers select. train. promote. and retire subordinates.

4. Planning--the process by which a manager looks to the tuture and discovers alternative courses of action open to him.

5. Controlling--the process that measures current performance and guides it toward some predetermined goal.

6. Communicating--the process by which ideas are transmitted to others for the purpose of effecting a desired result.

7. Directing--the process by which actual performance of subordinates is guided toward common goals (p. 6).

Mintzberg (1973) studied a group of executives at work and categorized the observations he made into groups of specific behaviors. These behaviors/roles are arranged into three distinct areas as shown in Table 2.

The first area, interpersonal roles, comprises activities that deal with the development of interpersonal relationships by the manager. The second category contains informational roles that enable the manager to receive and transmit information. 
The third category of behavior contains decisional roles. Mintzberg believes that these roles are the most crucial of all managerial activities.

TABLE 2

BEHAVIORAL ROLES

$\begin{array}{lll}\text { External Roles } & & \text { Internal Roles } \\ & \text { INTERPERSONAL } & \\ & \text { ROLES } & \\ \text { Figurehead } & \text { Liaison } & \text { Leader } \\ & \text { INFORMATIONAL } & \\ & \text { ROLES } & \\ \text { Spokesperson } & \text { Monitor } & \text { Disseminator } \\ & \text { DECISIONAL ROLES } & \\ \text { Entrepreneur Negotiator } & \text { Disturbance Handler } & \text { Resource Allocator }\end{array}$

Drucker (1954) observed that the manager is the dynamic. life-giving element in ev'ery business organization. Indeed. in today's competitive environment. the quality and performance of an organization's managers may determine its very survival. It was once generally believed that managers were born and not made. but now there is increasing acceptance of the idea that managerial skills. knowledge, and abilities can be learned and improved (Campbell, Dunnette, Lawler, \& Weick. 1970).

\section{Management Development}

Management training, management education, and both planned and unplanned on-the-job experiences are all potentially important inputs for a manager's development. 
Management development involves formalized education designed to develop a broad range of abilities that would enable managers to cope with a large variety of tasks in diverse organizational contexts. It is also regarded as instruction in highly specific managerial skills (e.g.. time management. delegation. managing conflict). which would be immediately applicable in a particular organizational setting. Still others consider development synonymous with career planning. job rotation. on-the-job experience, and coaching (Wexley \& Baldwin. 1984. pp. 277-294).

\section{Management Education}

Management education denotes those activities traditionally conducted by colleges and universities that focus on developing a broad range of managerial knowledge and general conceptual behavior. The major issue in management education today is the curriculum being offered in business schools. Advocates of the competency movement argue that managers and managers-to-be emerge trom management education programs insensitive to the nuances of organizational culture. lacking a true interest in managing. and. most important. deficient in the skills thought essential for effective management (Behrman \& Levin, 1984; Heisler \& Lasher, in press; Waters, 1980). Researchers also argue that educators have focused more on teaching individuals about management rather than how to manage, and that management students get few opportunities to learn about. practice. and become competent in behavioral skills essential for good management (Badaway, 1982; Heishler \& Lasher, in press; Waters, 1980).

Several writers have pointed to problems in the teaching of management competencies. Vaill (1983) attacked the competency movement and seriously questioned 
whether a skills-list definition of competency would accurately reflect how effective managers actually functioned. Other skeptics have contended that the role of education in general and management in particular should be much broader than the teaching of specific competencies (Johnston. 1986).

\section{Management Training}

Management training differs from management education in that training covers those activities designed to impart specific managerial skills (e.g.. time management. delegation). which would be immediately applicable in a particular organizational setting. Training may also focus on a manager's level of self-awareness or motivation (Wexley \& Latham. 1981). In this area. personal training reviewers tend to focus on needs assessment, training content and method. maximizing learning and transfer. and evaluation of special target groups (McGehee \& Thayer. 1961: Wexley, 1984).

\section{Leadership and Management in Organizations}

Ubben and Hughes (1992) argue that good leaders are also good managers. They also are of the opinion that it is essential to distinguish between "managing" and "doing." They continued: "Careful delegation, matching the skill and interest of staff members with functional aspects, and providing for a coordinated effort are elements of good management" (p. 10).

The dimensions of leadership and management cut across five functions, which can be listed as: (1) curriculum development, (2) instructional improvement, (3) student services, (4) financial and facility planning, and (5) community relations (Ubben \& 
Hughes. 1992. p. 10). Leadership in this context can be seen as the way principals use themselves to create a school climate characterized by student productivity. staff productivity. and creative thought. whereas when one thinks of good management it is seen as the systematic application of an array of skills to provide for an orderly and efficient school environ.

Leadership and management are not at opposite ends of the continuum. but can be regarded as complementary to each other and. at times. are synonymous. Effective leading and managing an organization require that all available human and financial resources be harnessed and organized in such a manner that the organization will function at a high level of efficiency.

\section{Issues in Technical/Vocational Education}

The dilemma that faces vocational education in Barbados is to develop a cadre of trained and competent vocational education administrators. This is an emerging view and a view accepted by the Ministry of Education. Elsewhere in this document is noted government's acknowledgment of the inefficiencies in the development and delivery of technical/vocational education. A review of literature has revealed that advanced leadership programs in vocational education appear to be a relatively recent undertaking. In the past, according to Wenrich and Wenrich (1974), most vocational administrators were recruited from teaching positions, and as vocational leaders they had a high degree of competency in a particular occupational field. The authors appealed for a new type of leadership in vocational education administration and submitted that 
leaders in vocational education can no longer follow their specialist role exclusively: They must be specialists in vocational education and behavioral scientists as well. .. . They must be able to relate vocational and technical education to business and industry, to government. and to education in general. They must be able to conceptualize the new and emerging relationships and set new goals for vocational education. (p. 102)

Wenrich and Wenrich's (1974) concern for a new breed of vocational/technical education leaders was echoed by the former president of the American vocational association. N. Edmunds stated:

Like business and industry. vocational education is engaged in a struggle to adapt to change. . . a struggle to survive. Simply to remain a viable part of American education. we need astute, creative leaders at all levels ... leaders for the ongoing work of delivering vocational education to the youth and adults of this nation. and leaders for professional associations. (Edmunds. 1988, p. 24)

Technical/rocational education administrators are expected to be the recipients of leadership-development programs geared toward the attainment of competencies necessary to their profession. It is necessary for Barbados and indeed the Caribbean to validate a list of tasks (competencies) relevant to their training and development needs.

\section{Future Challenges in Technica/Vocational Education}

The emergence of the career education thrust and the increasing interest of students and the general public in technical/vocational programs have generated a need for rapid expansion of employment-related education. This situation has resulted in attention being focused on technical/vocational administrators and their need for continuing professional development. Although a measure of emphasis has begun to be placed on professional preparation programs, there is still a need for the process to be reexamined and re-focused. 
Initiatives undertaken by the Barbados government and the mandate given to the University of West Indies. Erdiston Teachers' Training College, and indeed the tertiarylevel institutions have been incorporated as policy. This action by government will affect the future leadership and delivery of technical/vocational education. There are other concerns that will also impact on technical/vocational education and challenge its viability. In the forefront is the issue of integrating general and vocational education.

\section{Integration of General and Vocational Education}

In Barbados there is the continuing "general education vs. vocationalism" debate. Students are placed in an academic or vocational stream. It is imperative that this dichotomy between the two areas be avoided. Norton et al. (1987) noted that although each has a distinctive purpose. they are both related to occupation. Prosser and Quigley (1963) disagreed with the division and observed:

In a democratic system of education. every citizen should have as part of his training both types of education. General education should prepare us to be more intelligent as citizens and to understand and to enjoy life. Vocational education should prepare us to work more efficiently. Both are necessary to the well-equipped citizen. (p. 10)

Sagen (1981) also argued that the challenge to educational leadership is to unite the liberal and practical in a more effective pursuit of each as a worthy aim of human achievement. Another challenge to vocational education administrators is the promotion of school-to-work transition. The need exists for an apprenticeship program where students can become acquainted with the world of work so that they carry marketable skills to the workplace. Work-based alternatives for non-college-bound youth have 
become a necessity. Technical/vocational education administrators need to be sensitized to public expectations that ways be found for providing greater opportunity for technical/vocational education to be accessible to disadvantaged individuals.

\section{Related Studies in Leadership Roles and Professional Development}

This section of the review highlights related studies that are relevant to leadership roles and professional development of technical/vocational education administrators. Of particular relevance is the study done by Norton et al. ( 1987) as it contributes significantly to this study. The survey instrument used in this present study is i modified version of Norton`s instrument. and indeed Norton"s study provided the tramework and general guidelines that inform this current study.

Norton et al. (1987) sought to identify and to nationally verify the competencies important to secondary and post-secondary administrators of technical/vocational education. They also intended to discover whether there were significant differences in the ratings of importance given to tasks by (1) secondary versus post-secondary administrators; (2) administrators concerned with only vocational programs versus administrators concerned with both vocational and general educational programs: (3) secondary administrators concerned with only vocational programs versus secondary administrators concerned with both vocational and general education; and (4) post-secondary administrators concerned with only vocational programs versus postsecondary administrators concerned with both vocational and general education programs. 
The researchers expected that the identification of these competencies needed by vocational administrators would allow for the development of a base on which (1) needs assessment could be conducted: (2) competency-based instructional materials could be developed: and (3) high-quality pre-service and in-service education programs could be planned and implemented.

The respondents were asked to respond to a six-point Likert-type scale to two questions about each task statement. The questions were: (1) How important is the performance of this task in your job as an administrator? and (2) How difficult do most administrators tind it to learn to perform the task correctly? Additionally. a 12-item general information questionnaire was devised to gather demographic and other desired information about the respondents.

The committee identified 12 duty areas and 210 different tasks. It also reviewed the nine duties from the 1977 study to determine what changes could have been made. Four of the original duties were modified. four new areas were added. and four of the original retained. Thirty-five new tasks were identified by the committee.

A total of 128 of the nominated 188 administrators returned usable instruments for a return rate of $68 \%$. Of this total, 52 of the respondents were employed in secondarylevel agencies, 49 persons in post-secondary agencies, and 27 persons reported working in agencies that had both secondary and post-secondary students.

An arbitrary cutoff score of a mean of 2.5 or higher on the scale of task importance was used, and it resulted in 201 of the 210 tasks being declared as important. Only two statements received a mean score of less than 2.0 . 
The responses were also analyzed to determine whether there were any statistically significant differences in the way the four subgroups perceived the importance of the competencies. The following significant differences were obtained:

1. Secondary administrators rated 42 task statements significantly different than did the post-secondary administrators.

2. Vocational administrators rated 24 task statements significantly different than did administrators of both vocational and general programs.

3. Secondary vocational administrators rated 9 task statements significantly different than did secondary administrators of both vocational and general programs.

4. Post-secondary vocational administrators rated 9 task statements significantly different than did post-secondary administrators of both vocational and general programs.

It was concluded that the 35 new task statements should form the basis for the development of additional competency-based modules and guides for use by technical/vocational education leadership personnel.

Burns (1992) identified the roles/functions of Michigan career/technical education (CTE) administrators and identified their personal need for further preparation and continuing professional development. The population for the study consisted of 224 secondary CTE administrators. They responded to a 99-item survey questionnaire that described various roles/functions associated with the administration of CTE programs and arranged under nine major headings: Program Planning, Development, and Evaluation; Instructional Management; Student Services; Personnel Management; Staff Development; Professional Relations and Self-Development; School Community 
Relations: Facility and Equipment Management: and Business and Financial

Management. For each role descriptor. respondents were asked to indicate how important it was to their success as a CTE administrator.

The results indicated that CTE administrators perceived each category to be "moderately important" to "rery important" to their position. However. Professional Relations and Self-Development: Program Planning. Development. and Evaluation: and Staff Development were perceived to be the most important categories.

There were signiticant differences when respondents were compared by educational setting. educational background. and tenure in position with regard to their perceptions about the importance of their administrative roles/functions within the nine categories. Burns further reported that CTE administrators expressed a "moderate need" for further preparation in the major categories of roles/functions. The category of Program Planning. Development. and Evaluation was identified as the one in which CTE administrators had the highest need for professional development. Staff development was ranked second. and Professional Relations and Self-Development was ranked third.

There were no significant differences when the respondents were compared by educational background and tenure in position with regard to their perception of their need for further preparation within the nine categories. However, significant differences were found in the categories of Student Services, Facility and Equipment Management, and Business and Financial Management when CTE administrators were identified by educational setting. 
Lemmer ( 1992) sought to ascertain the perceptions of elementary-school principals about the relative importance of their school management functions and instructional leadership functions and the relative amount of time they actually spent on each kind of function. The researcher also wanted to determine whether there were differences in the perception of public-school principals and Catholic school principals about these matters. He also wanted to discover whether these perceptions differed according to the principal's gender. experience, and academic preparation.

Lemmer surveyed public elementary-school principals and Catholic elementary school principals in the Minneapolis-St. Paul area. The survey instrument. developed by the researcher. required respondents to indicate on a Likert-type scale their perceptions about "importance of" and "time spent on" each of 67 administrative tasks or activities that were organized into nine general categories: Supervision and Evaluation of Instruction: Home-School-Community Relations: Professional Development: Staff Personnel: School Finance and Business Management: Pupil Personnel: Program Development: School Plant Management; and Transportation Management.

The results indicated that from most to least important, the rankings were: Supervision and Evaluation of Instruction; Home-School-Community Relations; Professional Development; Staff Personnel; School Finance and Business Management; Program Development; Professional Development; Staff Personnel; School Plant Management, and lastly, Transportation Management. From most to least time spent, the rankings were: Supervision and Evaluation of Instruction; Home-School-Community Relations; Pupil Personnel; School Finance and Business Management; Program 
Development: Professional Development: Staff Personnel: School Plant Management. and lastly. Transportation Management.

Lemmer (1992) further reported that between public-school principals and Catholic school principals. differences in perceived "importance" were found for Program Development. Staff Personnel. and School Finance and Business Management: and differences in perceived "time spent on" were found for School Finance and Business Management. and Program Development. Based on gender. experience. and academic preparation. no differences were tound in perceptions about either "importance of" or "time spent on" any category.

The purpose of a study by Crudup (1991) was to examine the current and desired role of the local vocational education director of North Carolina as perceived by superintendents. principals, vocational teachers. and local vocational education directors. Crudup selected 67 functions and incorporated them into a Likert-type instrument. containing two additional parts for the collection of answers to several open-ended questions and selected characteristics of all respondents.

The findings revealed that local directors spent a major portion of their time on administrative functions. A moderate amount of time was spent on instructional and personnel matters, and the least amount of time on program-promoting tasks. All respondents appeared to have similar perceptions regarding the director's current level of involvement in personnel functions. However, there might have been some lack of understanding on the part of principals and vocational teachers regarding the director's 
involvement in administrative. instructional. and program-promotion tasks since their ratings were significantly lower than superintendents and directors.

Crudup (1991) also reported that all groups expressed the desire for directors to remain involved in administrative tasks at about the same level of their current involvement. They desired a greater level of director involvement in instructional tasks. All groups perceived the need for greater director involvement in program-promotion activities. He also stated that superintendents and local directors were frequently in agreement regarding the current role of the director. but their views regarding the desired role were less congruent.

Crudup also discovered that differences in perception existed among the four groups based on position. He further pointed out that. generally. years of experience. gender. and race did not influence the perceptions of the respondents but it was noticeable that respondents with more years of experience perceived the need for greater director involvement.

Caffrey (1989) sought to determine the management skills used by successful Connecticut public-school administrators and the priority of their importance. He set about the task by inquiring: (1) What management skills do superintendents, principals. and senior teachers in each cluster group identify as being needed? (2) What are the differences in the need for management skills among the superintendents, principals, and senior teachers? (3) What management skills do superintendents, principals, and senior teachers across the four clusters identify as being needed? (4) What are the differences in the identified need for management skills among the superintendents, principals, and 
senior teachers across the four clusters? (5) What are the similarities and differences in the identified need for management skills among the urban. suburban. and rural school districts? (6) What model can be drafted to summarize the data on the managerial skills identified and to compare the findings with the extant literature?

A researcher-developed questionnaire. based on relevant literature review. was utilized. Data were gathered through personal interviews with 16 experienced administrators and 12 senior teachers. These interviews were transcribed verbatim and analyzed for common themes. The management skills identitied were: Organizing: Planning: Delegating: Appraising: Scheduling; Mentoring: Monitoring: Budgeting: Motivating; Auditing; Assessing; and Recruiting. The researcher prioritized these management skills based on the respondents' information.

Caffrey (1989) reported that. through the study, it was evident that in order to successfully manage a school district and to provide effective instructional leadership. school administrators need to be able to use at least 12 skills as previously identified above. They must also possess unusually competent interpersonal skills to conduct the many facets of their job. The researcher developed a Education-Oriented Management Curriculum Model. which he hoped would enhance the professionalism of current and future administrators.

In an examination of the competencies needed by technical/vocational education administrators in the Kingdom of Saudi Arabia, Aldekhyyel (1988) sought to establish whether there were differences in perception of their importance among (1) vocational training-center administrators, (2) industrial, commercial, technical, and agricultural 
secondary-institute administrators. and (3) post-secondary commercial institute and College of Technology administratorsideans. The entire population of administrators was surveyed: 49 instruments were returned, representing a return rate of $84 \%$.

Aldekhyyel (1988) developed a list of competency statements from several sources and classified them in eight categories. Respondents were asked to indicate the level of importance of each specific competency to their job performance. It was discovered that all administrators rated the 153 competency statements valid and important and therefore necessary for technical/vocational education administrators. The post-secondary and College of Technology administrators were somewhat similar to the other two groups in their ranking of the eight major competency areas but different from them in their perception of the level of importance of the eight categories.

Anderson (1991) used six hypotheses in an analysis of the roles of high-school administrators as perceived by principals and assistant principals in selected Oklahoma public high schools. The first of these hypotheses. which predicted that there would be no difference in administrative behavior in dealing with school personnel. was retained. The second, which predicted that there would be no difference in administrative behavior when dealing with the school's instructional program, was rejected.

The third hypothesis, which predicted that there would be no difference in administrative behavior when dealing with student activities of the school, was rejected. Principals and their assistants saw no difference in their role behavior in dealing with the school's activity program. 
The fourth hypothesis. which predicted no difference in administrative role behavior in dealing with pupil personnel in the school. was accepted. The tifth hypothesis. which predicted no difference in administration behavior in managing the school. was rejected.

Anderson's sixth hypothesis. which predicted no difference in administrative beharior in dealing with community relations. was rejected. Null hypotheses $I$ and $t$ Were retained thus indicating that principals and assistant principals perceived no statistical difference in the level of involvement of administrative roles in working with school personnel and pupil personnel. Null hypotheses 2. 3.5. and 6 were also rejected. The researcher noted that this finding implied that principals and assistants perceived their role behavior differently as it pertained to working with the school's instructional program. student activity. school management. and community relations.

Some of the major findings of Anderson's study (1991) were:

1. Principals perceived assistant principals as full-time partners on the school's administrative team.

2. Assistant principals felt that they were still excluded from doing many of the tasks they would like to be doing.

3. Women and minority group members were underrepresented in the large public high schools in Oklahoma.

Hatch-Yap (1988) conducted a study to ascertain principals' perception of their role and the perceived effectiveness of educational administration programs as related to the role. The researcher developed a questionnaire based on universal statements 
defining administrative roles and categorized them into four task area subgroups:

Curriculum and Instruction. Staff Personnel. Pupil Personnel, and Management Function/Educational Leadership.

The population consisted of 1984-1987 midwestern university graduates with a Ph.D.. Ed.D., or Specialist Degree and currently a practicing principal. Items were to be evaluated using the delineation of (1) no emphasis. (2) low emphasis. (3) moderate emphasis. (4) high emphasis. and (5) superior emphasis.

The results revealed that:

1. Role and program ratings were unaffected by the following independent variables: Location of employing school. prior or present position. or total educational experience.

2. Role and program items. after being analyzed for their cohesiveness within groups. showed that seven of the eight subgroups' alpha score ranged from $80-90 \%$. with role staff personnel being $65 \%$. an acceptable score.

3. All 36 roles received "high emphasis" ratings. whereas principals perceived that educational administration programs placed "low or average emphasis" on the roles.

4. Role subgroup scores were $4.03,4.21,4.15$, and 4.20. The program subscore frequencies were $3.15,3.22,2.88$, and 3.36 respectively.

In another study, Freshour (1990) examined the responses of 234 administrators of secondary schools in Idaho, Montana, and Wyoming using a survey dealing with instructional leadership. The survey consisted of questions about present and ideal 
administrative functions and responsibility for functions. Vearly $80 \%$ of the respondents were principals and 20\% were superintendents.

The findings indicated that the most important role in present job performance was personnel matters $(30.5 \%)$. Under an ideal setting, more respondents (50.2\%) indicated instructional leadership. In the ideal school. activity management received no first-place rankings. and facility and equipment management was also near the bottom. Of eight choices given. personnel matters. motivation of staff and students. and instructional functions were primary responsibilities of the secondary administrators. almost $90 \%$.

Other findings in Freshour's (1990) study were:

1. Almost three-quarters of the administrators believed that they were responsible for public relations and community service.

2. Activity planning and management were a primary function of only 405 of the respondents.

3. Strong support was given to professional organizations as sources of training after certification: local and regional in-service came in second. and professional publications and university course work tied for third in the top-ranked choices.

4. Emphasis and training were statistically analyzed. The mean difference in responses were analyzed with $\underline{t}$ tests and all were found to be significant at an alpha of 0.01 . In all cases, emphasis exceeded training, with the greatest emphasis given to supervision and evaluation of instruction, protection of instructional time. promotion of professional development, and incentives for learning. 
Freshour concluded that the greatest mean difference between emphasis and training was on protection of instructional time, maintaining high visibility. promotion of professional development. and providing incentives for learning. The lowest ratings for training were given to monitoring student progress and communicating the school's goals.

Aitken (1992) focused his study on independent school heads and their expressed attitudes and opinions concerning their own professional development. He mailed a survey to all 988 members of the National Association of Independent Schools and 500 responded. He conducted telephone interviews with a small subsample of the respondents. Findings indicated that independent school heads identified the promotion of instructional climate and values as their preeminent leadership role. yet they assigned a medium priority rank to curriculum development.

The respondents viewed student discipline, teacher evaluation. and financial duties as managerial tasks with limited scope for leadership. Aitken concluded from the data that (1) independent schools may be "overmanaged and underfed." and (2) that regular assessment of the administrator-board relationship was important. He advocated the use of professional development programs as the means of addressing the problem.

\section{Caribbean Studies}

James (1976), in a proposal for the professional preparation of secondary-school principals in Jamaica, sought to develop training guidelines based on the development needs of the country, the perceived needs of those to be trained, and the roles, duties, and competencies of the trainees. The respondents were 68 secondary-school heads and 36 
others. comprising Ministry of Education officials, personnel from teacher-training institutions. and school board personnel.

James's recommendations based on findings were:

1. A new approach to educational administration in Jamaica

2. A comprehensive program for the professional preparation of secondaryschool principals in order to (a) sensitize them to their role. and (b) improve competency: on the job

3. The development and implementation of administrative training programs both in-service and pre-service by the Ministry of Education and the University of the West Indies (U.W.I.)

4. The involvement of professional organizations in in-service education programs.

Haye (1976) thought it necessary to formulate a model for a leadership development component of vocational agriculture programs in Jamaica. His sample was drawn from 40 Jamaican schools, staffed with vocational agriculture teachers. The respondents consisted of 12 school administrators, and 12 heads of department of vocational agriculture from the 12 selected schools.

The major findings were:

1. The school administrators were well qualified for the position when compared to the requirement established by the Ministry of Education.

2. Only one-half of the teachers in the sample possessed the level of education required by the Ministry of Education to teach vocational agriculture. 
3. Three-fourth of the teachers in the sample had 5 years or less of teaching experience. The mean rate 3.6. This meant that Jamaican schools were experiencing a high rate of turnover among vocational agriculture teachers.

4. The basic necessary resources were available for a leadership-development component.

5. Administrators and vocational agriculture teachers had a favorable attitude toward a large number of leadership-development activities.

6. Significant differences were observed in attitude toward leadership activities between the teacher group and the administrator group for three of the nine categories of leadership learning activities.

7. There were no significant differences between the attitudes of teachers and administrators for six of the nine categories of leadership learning activities. Haye used his findings to develop a proposed leadership-development model for vocational agriculture teachers.

\section{Summary}

In this review of literature, some factors affecting the preparation and continuing professional development of school administrators were discussed. A high degree of attention was given to leadership development and professional development issues that confront technical/vocational education administrators. It also highlighted some of the future challenges of technical/vocational education in Barbados. The discussion articulated aspects of the Barbados government Development Plan 1963-2000 as it related to educational planning, training, and manpower needs. The training needs and 
certification of school administrators. in general. and technical/vocational education administrators. specifically. were examined and highlighted. 


\section{CHAPTER III}

\section{METHODOLOGY}

\section{Introduction}

The purpose of this study was to identify the roles/functions of technical/vocational education (TVE) administrators in Barbados and to ascertain their perceived need for further preparation and continuing professional development. In this chapter is presented the research design, the selection of subjects, the instrumentation. the procedure for collection of data. and the data analysis.

\section{Research Design}

A descriptive survey design was used for this study. The focus of the study was to identify the roles/functions of technical/vocational education (TVE) administrators in Barbados and to ascertain their need for further preparation and continuing professional development.

An attempt was also made to determine the relationship between certain selected demographic variables and how TVE administrators perceived their administrative roles/functions. These variables include gender, age, years of experience as TVE 
administrators. job status. educational setting of employment. highest level of education. and the focus of undergraduate and graduate degree programs.

The design used for the study was selected because it facilitated the data collection in a manner that allowed the respondents to state their perceptions as solicited by specific questions. Tuckman (1978) explained that questionnaires are frequently used by researchers to convert into data the information directly given by a person (subject). He further stated that this type of instrument allowed the researcher to measure what a person knew. liked or disliked. and what a person thought.

In discussing the application of educational research. Borg (1981) explained that since education is a new science a descriptive research is important to education, for much of the work in a new science is descriptive. He also noted that it was typical for researchers to utilize questionnaires and interviews to determine the opinions. attitudes. preferences. and perceptions of persons of interest to the researcher.

\section{Population}

The population used in this study consisted of technical/vocational education administrators from: (1) the central office of the Ministry of Education, (2) principals and head of departments of tertiary education institutions, and (3) principals and head of departments of the 22 public secondary schools in Barbados. These respondents were chosen because of the pivotal role they performed in the delivery of technical/vocational education in Barbados.

The respondents from the central office of the Ministry of Education were chosen because they are responsible to government for ensuring that government's plans and 
policies are implemented in educational institutions in the country. The principal is the chief curriculum planner and initiator of the institution and is responsible for program planning. implementation. and evaluation.

The head of department supervises the department and is concerned with the daily operation of the department. coordinates the instructional process. assigns responsibilities to teachers. and ensures that the department is operational. The head of department is also responsible for a particular specialty in the technical/vocational education program. In this study the specialties are: (1) Industrial Arts. (2) Home Economics. (3) Business Studies. and (4) Art and Craft. The tertiary institutions sampled were: Erdiston Teachers Training College, The Barbados Community College. and The Samuel Jackman Prescod Polytechnic.

The population included eight administrators from the central office of the Ministry of Education. 24 administrators from tertiary institutions, and 83 administrators trom the public secondary schools. which combined to result in a population of 115 .

\section{Instrumentation}

The instrument used in this study was a previously administered questionnaire modified by the researcher to satisfy the needs of this study. A closed-type 87-item questionnaire, which included 79 items that listed various role descriptors associated with the administration of TVE programs and 8 items that provided demographic information about the respondents, was used for the collection of data for the study (see Appendix A). Items for the questionnaire were selected from a study conducted by the National Center for Research in Vocational Education, Ohio State University (Norton et al., 1987), which 
identified and nationally validated competencies which were necessary for TVE administrators.

The questionnaire was divided into eight sections or categories. namely. Program Planning, Development. and Evaluation: Instructional Management: Personnel Management: Staff Development: Protessional Relations and Self-Development: SchoolCommunity Relations: Facilities and Equipment, and Business and Financial Management.

In order to identify and verify the competencies that were required for TVE administrators in Barbados. the original instrument was administered to a panel of seven educational administrators from Barbados. other Caribbean countries. and from Commonwealth countries. All members of the panel were educated familiar with the system of education that presently existed in Barbados as they were educated under a similar system. They drew on their own professional experience and from relevant literature on the subject. as they considered and recommended competencies which they viewed as relevant to TVE administrators in Barbados.

The panel was asked to evaluate the instrument for content validity and give comments concerning the clarity and appropriateness of the items, the placing of items in sections, the format. and the general suitability of the instrument for TVE administrators. Based on the feedback from the panel, the Ohio State instrument of 201 items was reduced to 79 items. Two categories, Student Services and Transport and Communication Services, and several individual items, not considered relevant to the operation of schools in Barbados, were eliminated. The panel was asked to recommend 
additional items but indicated there was no need for items other than those already in the instrument. As a result of the responses from the panel. adjustments were made to improve the appearance and understandability of the questions. The revised questionnaire was further reviewed by the panel of seven individuals and they decided that no further revisions of the instrument were needed.

The data-collecting instrument for this study was a survey questionnaire with 87 items. The survey included 79 items which listed various role descriptors associated with the administration of TVE programs. For each role descriptor. respondents were asked to indicate (1) how important the role/function was to their role as a TVE administrator and (2) their personal need for further preparation and continuing professional development in order to be as effective as they would like to be in each of the roles/functions listed. The survey questionnaire also included eight items that provided demographic information about each respondent.

\section{Data Collection Procedure}

I personally supervised the collection of the data for this study. The questionnaires were produced at Andrews University and I took them to Barbados where they were administered. The questionnaires were numbered for each set of respondents.

A letter was sent to the Ministry of Education in Barbados, stating the desire to undertake the study and requesting permission from the respective school boards to administer the study (Appendix A). Upon receiving permission, I visited each educational institution, where a personal letter of introduction was presented to each respondent (Appendix A), and I personally administered the questionnaires to 
technical/vocational education administrators in the central office of the Ministry of Education. principals and heads of departments of tertiary institutions. namely. The Barbados Community College. Erdiston Teachers' Training College. and The Samuel Jackman Prescod Polytechnic: and finally to principals and heads of departments of public secondary schools. Each respondent was assured of the confidentiality of the exercise.

I met with respondents in the various institutions and individually issued the questionnaire to each respondent. Time was spent with respondents in order to answer any queries presented by respondents. In some institutions, principals or their appointees undertook the responsibility for the collection of the finished instrument and ensured that they were safely and contidentially secured until they handed them over to me. In most cases I collected the completed questionnaires and reviewed them in order to ensure that issued guidelines and procedures were followed. I revisited institutions as was necessary and spent time with administrators explaining any questions or issues that arose. It also afforded me the opportunity to generate an appropriate environment in which the instrument could be administered.

A total of 153 questionnaires were issued and a total of 115 were returned. Of the returned questionnaires. 8 respondents were from the central office of the Ministry of Education. 12 respondents each were from tertiary institutions and vocational centers. 30 respondents from Grammar schools, and 53 from Newer secondary schools. Some difficulty was experienced at one Grammar school where the principal explained that the school's schedule could not allow for the researcher to personally administer the 
questionnaire and I was requested to return on a subsequent date to collect the completed questionnaires. After several unsuccessful telephone calls to the principal and return trips to the school. the principal offered to mail the completed questionnaires to me. No completed questionnaires were received from the school.

\section{Research Questions and Hypotheses}

\section{Research Questions}

The following research questions and hypotheses were addressed in this study:

1. What do technical/vocational education administrators perceive to be the range of importance in each of the selected roles/functions?

2. What differences exist among technical/vocational education administrators regarding their perceptions about roles/functions, comparing the variables of educational background. tenure in position. and educational setting.

3. What do technical/vocational education administrators perceive to be their degree of need for further preparation and continuous professional development in each of the selected roles/functions?

4. What differences exist among technical/vocational education administrators regarding their professional development needs, comparing the variables of educational background. tenure in position, and educational setting?

\section{Hypotheses}

The null hypotheses were: 
1. There are no significant differences among technical/rocational education administrators about roles/functions on the basis of their educational background.

2. There are no significant differences among technical/vocational education administrators about roles/functions on the basis of their tenure in office.

3. There are no significant differences among technical/vocational education administrators about roles/functions on the basis of their educational setting.

4. There are no significant differences among technical/vocational education administrators about their professional development needs on the basis of educational background.

5. There are no significant differences among technical/vocational education administrators about their protessional development on the basis of tenure in position.

6. There are no significant differences among technical/vocational education administrators about their professional development needs on the basis of educational setting.

\section{Data Analysis}

The population as a whole was described in terms of demographic information stated in the questionnaire. Technical/vocational education administrators' overall perceptions of the importance of roles/functions and need for further professional development were described within eight major categories and further described as specific items within each category. The eight major categories were: (1) Program Planning, Development, and Evaluation; (2) Instructional Management; (3) Personnel Management; (4) Staff Development; (5) Professional Relations and Self-Development: 
(6) School/Community Relations: (7) Facility and Equipment Management. and (8) Business and Financial Management.

To determine the level of importance. a 5 -point scale was used ranging from "Not Important" to "Very Important." with I being "Not Important" and 5 being "Very Important." The mean score for each major category and the individual items within each major category were rank ordered to determine the roles/functions that were perceived to be of most importance.

A second 5-point scale was used to determine the perceived need for further preparation and continuing professional development for each role descriptor. Respondents were asked to indicate the need on a scale of 1 to 5 . ranging from "No Need" to "High Need." with 1 being "No Need" and 5 being "High Need." The mean scores for each major category and the individual items within each category were then ranked ordered to determine the roles/functions that were perceived to be most needed for turther preparation and professional development.

A major category or individual role descriptor was judged important or a priority need if it received an average rating of more than 3.75 . To determine the range of importance of a given category. or role/function. and its perceived training needs. the following scale was used: $1.00-2.50$, Not Important/No Need; $2.51-3.75$, Little Importance/Little Need; and 3.76+, Very Important/High Need.

Second, the perceived importance of the roles/functions and their training needs of the sample was compared among the various categories of independent variables: educational background, tenure in position, and educational setting. 
In response to hypotheses $1-6$. one-way analysis of variance was used with Student Newman Keuls ${ }^{\circ}$ post hoc multiple comparison test with an alpha of 0.05 in order to determine if there were any differences among groups of TVE administrators. Oneway analysis of variance was also done to identify the significant roles/functions within each major category. The assumption was made that the responses used interval data.

\section{Summary}

This chapter included information on the design of the study. It discussed the population. which referred to technical/vocational education administrators: the instrumentation. which referred to the type of instrument used to collect data: methodology of collecting data. the process used to collect information: hypotheses to be tested in analysis: analysis of data: and the weaknesses of the study.

This study was limited to technical/vocational education administrators in the central office of the Ministry of Education. and in secondary and post-secondary education institutions in Barbados. One survey instrument was used consisting of 87 questions. including 79 items which listed various role descriptors associated with the administration of TVE programs and 8 questions that provided demographic information about each respondent.

The data were collected directly from technical/vocational education administrators. The analysis of data was descriptive utilizing one-way analysis of variance with Student Newman Keuls' post hoc multiple comparison test with an alpha of 0.05 to determine which categories or individual roles within the categories were considered to be significant. 


\section{CHAPTER III}

\section{METHODOLOGY}

\section{Introduction}

The purpose of this study was to identify the roles/functions of technical/vocational education (TVE) administrators in Barbados and to ascertain their perceived need for further preparation and continuing professional development. In this chapter is presented the research design. the selection of subjects, the instrumentation. the procedure for collection of data, and the data analysis.

\section{Research Design}

A descriptive survey design was used for this study. The focus of the study was to identify the roles/functions of technical/vocational education (TVE) administrators in Barbados and to ascertain their need for further preparation and continuing professional development.

An attempt was also made to determine the relationship between certain selected demographic variables and how TVE administrators perceived their administrative roles/functions. These variables include gender, age, years of experience as TVE 
administrators. job status. educational setting of employment, highest level of education. and the focus of undergraduate and graduate degree programs.

The design used for the study was selected because it facilitated the data collection in a manner that allowed the respondents to state their perceptions as solicited by specific questions. Tuckman (1978) explained that questionnaires are frequently used by researchers to convert into data the information directly given by a person (subject). He further stated that this type of instrument allowed the researcher to measure what a person knew. liked or disliked. and what a person thought.

In discussing the application of educational research, Borg (1981) explained that since education is a new science a descriptive research is important to education. for much of the work in a new science is descriptive. He also noted that it was typical for researchers to utilize questionnaires and interviews to determine the opinions, attitudes. preferences. and perceptions of persons of interest to the researcher.

\section{Population}

The population used in this study consisted of technical/vocational education administrators from: (1) the central office of the Ministry of Education, (2) principals and head of departments of tertiary education institutions, and (3) principals and head of departments of the 22 public secondary schools in Barbados. These respondents were chosen because of the pivotal role they performed in the delivery of technical/vocational education in Barbados.

The respondents from the central office of the Ministry of Education were chosen because they are responsible to government for ensuring that government's plans and 
policies are implemented in educational institutions in the country. The principal is the chief curriculum planner and initiator of the institution and is responsible for program planning, implementation. and evaluation.

The head of department supervises the department and is concerned with the daily operation of the department. coordinates the instructional process. assigns responsibilities to teachers. and ensures that the department is operational. The head of department is also responsible for a particular specialty in the technical/vocational education program. In this study the specialties are: (1) Industrial Arts. (2) Home Economics. (3) Business Studies, and (4) Art and Craft. The tertiary institutions sampled were: Erdiston Teachers Training College. The Barbados Community College. and The Samuel Jackman Prescod Polytechnic.

The population included eight administrators from the central office of the Ministry of Education, 24 administrators from tertiary institutions, and 83 administrators from the public secondary schools. which combined to result in a population of 115 .

\section{Instrumentation}

The instrument used in this study was a previously administered questionnaire modified by the researcher to satisfy the needs of this study. A closed-type 87 -item questionnaire, which included 79 items that listed various role descriptors associated with the administration of TVE programs and 8 items that provided demographic information about the respondents, was used for the collection of data for the study (see Appendix A). Items for the questionnaire were selected from a study conducted by the National Center for Research in Vocational Education, Ohio State University (Norton et al.. 1987), which 
identified and nationally validated competencies which were necessary for TVE administrators.

The questionnaire was divided into eight sections or categories. namely. Program Planning. Development. and Evaluation: Instructional Management: Personnel Management: Staff Development: Professional Relations and Self-Development: SchoolCommunity Relations: Facilities and Equipment. and Business and Financial Management.

In order to identify and verify the competencies that were required for TVE administrators in Barbados. the original instrument was administered to a panel of seven educational administrators from Barbados, other Caribbean countries, and from Commonwealth countries. All members of the panel were educated familiar with the system of education that presently existed in Barbados as they were educated under a similar system. They drew on their own professional experience and from relevant literature on the subject. as they considered and recommended competencies which they viewed as relevant to TVE administrators in Barbados.

The panel was asked to evaluate the instrument for content validity and give comments concerning the clarity and appropriateness of the items, the placing of items in sections, the format, and the general suitability of the instrument for TVE administrators. Based on the feedback from the panel. the Ohio State instrument of 201 items was reduced to 79 items. Two categories, Student Services and Transport and Communication Services, and several individual items, not considered relevant to the operation of schools in Barbados, were eliminated. The panel was asked to recommend 
additional items but indicated there was no need for items other than those already in the instrument. As a result of the responses from the panel. adjustments were made to improve the appearance and understandability of the questions. The revised questionnaire was further reviewed by the panel of seven individuals and they decided that no further revisions of the instrument were needed.

The data-collecting instrument for this study was a survey questionnaire with 87 items. The survey included 79 items which listed various role descriptors associated with the administration of TVE programs. For each role descriptor. respondents were asked to indicate ( 1 ) how important the role/function was to their role as a TVE administrator and (2) their personal need for further preparation and continuing professional development in order to be as effective as they would like to be in each of the roles/functions listed. The survey questionnaire also included eight items that provided demographic information about each respondent.

\section{Data Collection Procedure}

I personally supervised the collection of the data for this study. The questionnaires were produced at Andrews University and I took them to Barbados where they were administered. The questionnaires were numbered for each set of respondents.

A letter was sent to the Ministry of Education in Barbados, stating the desire to undertake the study and requesting permission from the respective school boards to administer the study (Appendix A). Upon receiving permission, I visited each educational institution, where a personal letter of introduction was presented to each respondent (Appendix A), and I personally administered the questionnaires to 
technical/vocational education administrators in the central office of the Ministry of Education. principals and heads of departments of tertiary institutions, namely. The Barbados Community College. Erdiston Teachers' Training College. and The Samuel Jackman Prescod Polytechnic: and finally to principals and heads of departments of public secondary schools. Each respondent was assured of the confidentiality of the exercise.

I met with respondents in the various institutions and individually issued the questionnaire to each respordent. Time was spent with respondents in order to answer any queries presented by respondents. In some institutions. principals or their appointees undertook the responsibility for the collection of the finished instrument and ensured that they were safely and confidentially secured until they handed them over to me. In most cases I collected the completed questionnaires and reviewed them in order to ensure that issued guidelines and procedures were followed. I revisited institutions as was necessary and spent time with administrators explaining any questions or issues that arose. It also afforded me the opportunity to generate an appropriate environment in which the instrument could be administered.

A total of 153 questionnaires were issued and a total of 115 were returned. Of the returned questionnaires, 8 respondents were from the central office of the Ministry of Education, 12 respondents each were from tertiary institutions and vocational centers, 30 respondents from Grammar schools, and 53 from Newer secondary schools. Some difficulty was experienced at one Grammar school where the principal explained that the school's schedule could not allow for the researcher to personally administer the 
questionnaire and I was requested to return on a subsequent date to collect the completed questionnaires. After several unsuccessful telephone calls to the principal and return trips to the school. the principal offered to mail the completed questionnaires to me. No completed questionnaires were received from the school.

\section{Research Questions and Hypotheses}

\section{Rescarch Questions}

The following research questions and hypotheses were addressed in this study:

1. What do technical/vocational education administrators perceive to be the range of importance in each of the selected roles/functions?

2. What differences exist among technical/vocational education administrators regarding their perceptions about roles/functions, comparing the variables of educational background. tenure in position, and educational setting.

3. What do technical/vocational education administrators perceive to be their degree of need for further preparation and continuous professional development in each of the selected roles/functions?

4. What differences exist among technical/vocational education administrators regarding their professional development needs, comparing the variables of educational background, tenure in position, and educational setting?

\section{Hypotheses}

The null hypotheses were: 
1. There are no significant differences among technical/vocational education administrators about roles/functions on the basis of their educational background.

2. There are no significant differences among technical/vocational education administrators about roles/functions on the basis of their tenure in office.

3. There are no significant differences among technical/vocational education administrators about roles/functions on the basis of their educational setting.

4. There are no significant differences among technical/vocational education administrators about their professional development needs on the basis of educational background.

5. There are no significant differences among technical/vocational education administrators about their professional development on the basis of tenure in position.

6. There are no significant differences among technical/vocational education administrators about their professional development needs on the basis of educational setting.

\section{Data Analysis}

The population as a whole was described in terms of demographic information stated in the questionnaire. Technical/vocational education administrators' overall perceptions of the importance of roles/functions and need for further professional development were described within eight major categories and further described as specific items within each category. The eight major categories were: (1) Program Planning, Development, and Evaluation; (2) Instructional Management; (3) Personnel Management: (4) Staff Development; (5) Professional Relations and Self-Development: 
(6) School/Community Relations: (7) Facility and Equipment Management. and (8) Business and Financial Management.

To determine the level of importance. a 5-point scale was used ranging from "Not Important" to "Very Important." with 1 being "Not Important" and 5 being "Very Important." The mean score for each major category and the individual items within each major category were rank ordered to determine the roles/functions that were perceived to be of most importance.

A second 5-point scale was used to determine the perceived need for further preparation and continuing professional development for each role descriptor.

Respondents were asked to indicate the need on a scale of 1 to 5. ranging from "No Need" to "High Need." with I being "No Need" and 5 being "High Need." The mean scores for each major category and the individual items within each category were then ranked ordered to determine the roles/functions that were perceived to be most needed for further preparation and professional development.

A major category or individual role descriptor was judged important or a priority need if it received an average rating of more than 3.75 . To determine the range of importance of a given category, or role/function, and its perceived training needs, the following scale was used: $1.00-2.50$, Not Important/No Need; 2.51 - 3.75, Little Importance/Little Need; and 3.76+, Very Important/High Need.

Second, the perceived importance of the roles/functions and their training needs of the sample was compared among the various categories of independent variables: educational background, tenure in position, and educational setting. 
In response to hypotheses 1-6, one-way analysis of variance was used with Student Newman Keuls' post hoc multiple comparison test with an alpha of 0.05 in order to determine if there were any differences among groups of TVE administrators. Oneway analysis of variance was also done to identify the significant roles/functions within each major category. The assumption was made that the responses used interval data.

\section{Summary}

This chapter included information on the design of the study. It discussed the population. which referred to technical/vocational education administrators: the instrumentation. which referred to the type of instrument used to collect data: methodology of collecting data, the process used to collect information: hypotheses to be tested in analysis: analysis of data: and the weaknesses of the study.

This study was limited to technical/vocational education administrators in the central office of the Ministry of Education. and in secondary and post-secondary education institutions in Barbados. One survey instrument was used consisting of 87 questions, including 79 items which listed various role descriptors associated with the administration of TVE programs and 8 questions that provided demographic information about each respondent.

The data were collected directly from technical/vocational education administrators. The analysis of data was descriptive utilizing one-way analysis of variance with Student Newman Keuls' post hoc multiple comparison test with an alpha of 0.05 to determine which categories or individual roles within the categories were considered to be significant. 
CHAPTER IV

\section{PRESENTATION AND ANALYSIS OF THE DATA}

The purpose of this study was to identify the roles/functions of technical/vocational education administrators in Barbados and to identify the personal needs for further education and continuing professional development. The study also addressed the self-perceived difference between survey respondents according to their educational background. tenure in position. and educational setting.

Presented in this chapter are the analysis and interpretation of the data gathered from the responses of 115 technical/vocational education (TVE) administrators in Barbados to the survey instrument that was used for the study. The survey instrument included the demographic factors of the sampled population and 79 items which described various roles/functions associated with the administration of TVE programs. It assessed the range of importance of the roles/functions in TVE administrative positions and identified the perceived needs for further preparation and continuing professional development. Four research questions were addressed in the study. It also reports on the data yielded from testing six hypotheses.

One hundred fifty-three technical/vocational education administrators in Barbados were given survey instruments. Of that number, 115 returned usable survey forms for a response rate of $75 \%$. 
The responses indicate that $69(60 \%)$ of the respondents were males and 46 $(40 \%)$ were females. The largest group of the respondents. $53(46.1 \%)$, identified themselves in the range of $41-50$ years of age. Forty-three of the respondents $(37.4 \%)$ were 51 years of age or older. and 19 respondents (16.5\%) were less than 41 years of age. These data are summarized in Tables 3 and 4.

\section{TABLE 3}

DEMOGRAPHIC CHARACTERISTICS: GENDER $(\underline{N}=115)$

\begin{tabular}{lcc}
\hline Gender & No. & $\%$ \\
\hline Males & 69 & 60 \\
Females & 46 & 40 \\
\hline
\end{tabular}

TABLE 4

DEMOGRAPHIC CHARACTERISTICS:

AGE $(\underline{N}=115)$

\begin{tabular}{lccc}
\hline Age & Male & Female & Total \\
\hline $30-40$ years & 12 & 07 & 19 \\
$41-50$ years & 32 & 21 & 53 \\
$50+$ years & 25 & 18 & 43 \\
\hline
\end{tabular}

In response to the question of how long they had administered technical/vocational education programs, $41(35.7 \%)$ of the respondents reported that 
they had administered such programs for II years or longer. An equal number of administrators. $37(32.2 \%)$. served $0-5$ years and 6-10 years. respectively. in technical/vocational education. These data are summarized in Table 5.

\section{TABLE 5}

TEACHING EXPERIENCE $(\underline{\mathrm{N}}=115)$

\begin{tabular}{lccc}
\hline No. of Years & Male & Female & Total \\
\hline $0-5$ years & 21 & 16 & 37 \\
$6-10$ years & 24 & 13 & 37 \\
$11+$ years & 24 & 17 & +1 \\
\hline
\end{tabular}

Fifty-three $(46.1 \%)$ of respondents indicated that they worked in a Newer secondary school, $30(26.1 \%)$ said that they worked in a Grammar school. and 32 $(27.8 \%)$ of the respondents reported that they worked in other institutions. These data are summarized in Table 6.

When asked to indicate their present job status, $63(54.8 \%)$ technical/vocational education administrators indicated that they were permanently employed. $33(28.7 \%)$ were appointed in their job, and 19 (16.5\%) of respondents were classified "other." These data are summarized in Table 7.

In response to the question of the highest level of education attained by technical/vocational education administrators, $51(44.7 \%)$ reported that they had a baccalaureate degree; an additional $41(36.0 \%)$ held certification below baccalaureate 
degree level. and 22 (19.3\%) of the respondents held master's degrees and above. These data are summarized in Table 8.

TABLE 6

EDUCATIONAL SETTING $(\underline{N}=115)$

\begin{tabular}{lccc}
\hline Institution & Male & Female & Total \\
\hline Grammar School & 18 & 12 & 30 \\
Newer Secondary & 33 & 20 & 53 \\
Other & 18 & 14 & 32 \\
\hline
\end{tabular}

TABLE 7

JOB STATUS $(\underline{N}=115)$

\begin{tabular}{lccc}
\hline Job Status & Male & Female & Total \\
\hline Permanent & 35 & 28 & 63 \\
Appointed & 22 & 11 & 33 \\
Other & 12 & 07 & 19 \\
\hline
\end{tabular}

TABLE 8

HIGHEST LEVEL OF EDUCATION $(\underline{N}=115)$

\begin{tabular}{lccc}
\hline Level of Education. & Male & Female & Total \\
\hline <B.A. & 26 & 15 & 41 \\
B.A. & 29 & 22 & 51 \\
Graduate & 14 & 8 & 22 \\
\hline
\end{tabular}


Fifty-five (50\%) TVE administrators had an undergraduate program focus in general education. while $33(30 \%)$ of them reported a vocational education emphasis. and $22(20 \%)$ said that their program focused on some other area. When compared to their graduate program focus. a majority of the respondents. 35 (59.3\%), reported general education. while $9(15.3 \%)$ reported that they had a graduate focus in vocational education administration. The remaining respondents. 15 (23.4\%), reported that their graduate emphasis was in areas other than the two areas mentioned. These data are summarized in Tables 9 and 10.

\section{Results From Research Questions}

Four research questions were formulated to serve the purpose of the study. In the following pages. each research question is restated followed by a report of the data pertaining to that question.

\section{Research Question 1}

Research Question 1 asked: What do technical/vocational educational administrators perceive to be the range of importance in each of the selected roles/functions?

The various roles/functions associated with the administration of technical/vocational education have been organized into the following eight major categories: (1) Program Planning Development, and Evaluation; (2) Instructional Management; (3) Personnel Management; (4) Staff Development; (5) Professional Relations and Self-Development; (6) School/Community Relations; (7) Facilities and 
Equipment. and (8) Business and Financial Management. Within each major category. the TVE administrators' perceptions of the various roles/functions ranged in importance.

TABLE 9

PROGRAM FOCUS. UNDERGRADUATE $(\underline{\mathrm{N}}=[10)$

\begin{tabular}{lccc}
\hline Program & Male & Female & Total \\
\hline General Ed. & 32 & 23 & 55 \\
Vocational Ed. & 20 & 13 & 33 \\
Other & 12 & 10 & 22 \\
\hline
\end{tabular}

TABLE 10

PROGRAM FOCUS, GRADUATE $(\underline{\mathrm{N}}=59)$

\begin{tabular}{lccc}
\hline Program & Male & Female & Total \\
\hline General Ed. & 19 & 16 & 35 \\
Vocational Ed. & 4 & 5 & 9 \\
Other & 7 & 8 & 15 \\
\hline
\end{tabular}

from "not important/no need" ( 1 on the scale) to "very important/high need" ( 5 on the scale). A given category was considered "not important/no need" if it had a mean score of between 1.00 and 2.50; of "little importance/little need" if the mean scores were between 2.51 and 3.75; and "very important/high need" if the mean scores were higher than 3.75 . 
Technical/vocational education administrators identified Professional Relations and Self-Development with a mean score of 4.33 to be the most important category: followed by Staff Development with a mean score of 4.25: Personnel Management, with a mean score of 4.22: Program Planning Development and Evaluation with a mean score of 4.18: Facilities and Equipment with a mean score of 4.06: and Instructional Management with a mean score of 3.97 .

School/Community Relations was viewed by TVE administrators as the category of least importance with a mean score of 3.66. They also regarded Business and Financial Management similarly. These data are summarized in Table 11 .

TABLE 11

TVE ADMINISTRATORS' PERCEPTIONS OF THE IMPORTANCE OF ROLES/FUNCTIONS BY MAJOR CATEGORIES $(\underline{N}=115)$

\begin{tabular}{llcc}
\hline Major Categories & Mean & $\underline{\text { SD }}$ & Rank \\
\hline $\begin{array}{l}\text { 1. Program Planning. Development \& Evaluation. } \\
\text { (12 items) }\end{array}$ & $4.18^{*}$ & 0.55 & 4 \\
$\begin{array}{l}\text { 2. Instructional Management (16 items) } \\
\text { 3. Personnel Management (10 items) }\end{array}$ & $3.97^{*}$ & 0.56 & 6 \\
4. Staff Development (5 items) & $4.22^{*}$ & 0.68 & 3 \\
$\begin{array}{l}\text { 5. Professional Relations \& Self-Development } \\
\text { (9 items) }\end{array}$ & $4.25^{*}$ & 0.63 & 2 \\
6. School/Community Relations (9 items) & $4.33^{*}$ & 0.57 & 1 \\
7. Facilities \& Equipment (10 items) & 3.66 & 0.81 & 8 \\
8. Business \& Financial Management (8 items) & 3.75 & 1.01 & 7 \\
\hline
\end{tabular}

*Met criteria for "very important" category. 
In the category of Program Planning. Development. and Evaluation. the most important individual role as perceived by technical/vocational education administrators was item 9. recommend curriculum revisions. with a mean score of 4.44 . It was followed by item 1 . survey student interests. with a mean score of 4.39 and. item 4 , prepare an annual plan for delivering technical/vocational education. with a mean score of 4.37 .

Item 7. conduct student follow-up studies, was viewed as the item of least importance with a mean score of 3.85 . It was followed by item 10. write proposals for the funding of new programs and the improvement of existing programs, and item 11 . contract instructional programs with business and industry, both with a mean score of 3.90. Based on the criteria set by the researcher, all items in the category were perceived by TVE administrators to be very important. These data are summarized in Table 12. In the category of Instructional Management, the individual role considered most important was item 18, guide staff in selecting and using effective instructional strategies. with a mean score of 4.49. Item 15. provide student discipline, and item 20. guide staff in integrating and articulating the technical/vocational program with the total educational program. both with a mean score of 4.32 , followed in importance as perceived by TVE administrators. The item of least importance was item 23, direct the adult and continuing education programs, with a mean of 3.23 ; followed by item 24 , guide the articulation of secondary and post-secondary technical/vocational education programs, with a mean of 3.60 ; and item 22 , provide technical assistance in the development of customized training programs for business and industry, with a mean of 
3.61. Thirteen of the 16 items. based on the criteria set by the researcher. were perceived by TVE administrators to be very important. These data are summarized in Table 13.

TABLE 12

TVE ADMINISTRATORS` PERCEPTIONS OF THE IMPORTANCE OF PROGRAM PLANNING. DEVELOPMENT. AND EVALUATION ( $N=115$ )

\begin{tabular}{|c|c|c|c|}
\hline Item Content & Mean & $\underline{\mathrm{SD}}$ & Rank \\
\hline 1. Survey student interest & $4.39 *$ & 0.77 & 2 \\
\hline 2. Analyze labor demand data & $4.04^{*}$ & 0.99 & 9 \\
\hline $\begin{array}{l}\text { 3. Direct course/program planning \& development } \\
\text { efforts }\end{array}$ & $4.31 *$ & 0.86 & 6 \\
\hline $\begin{array}{l}\text { 4. Prepare an annual plan for technical/voc. } \\
\text { education }\end{array}$ & $4.37^{*}$ & 0.85 & 3 \\
\hline $\begin{array}{l}\text { 5. Prepare a } 3-5-y r \text {. plan for overall program } \\
\text { improvement }\end{array}$ & $4.08^{*}$ & 0.89 & 8 \\
\hline 6. Conduct course/program review & $4.34^{*}$ & 0.86 & + \\
\hline 7. Conduct student follow-up studies & $3.85^{*}$ & 0.97 & 12 \\
\hline 8. Assess student competency & $4.33^{*}$ & 0.86 & 5 \\
\hline 9. Recommend curriculum revisions & $4.44^{*}$ & 0.76 & 1 \\
\hline $\begin{array}{l}\text { 10. Write proposal for funding new programs \& } \\
\text { improvement of existing programs }\end{array}$ & $3.90^{*}$ & 1.10 & 10 \\
\hline $\begin{array}{l}\text { 11. Contract instructional programs w/ } \\
\text { business/industry }\end{array}$ & $3.90^{*}$ & 0.98 & 11 \\
\hline $\begin{array}{l}\text { 12. Develop supplement/remedial instructional } \\
\text { programs }\end{array}$ & $4.17^{*}$ & 0.98 & 7 \\
\hline
\end{tabular}

*Met criteria for "very important" category. 
TABLE 13

TVE ADMINISTRATORS` PERCEPTION OF THE IMPORTANCE OF INSTRUCTIONAL MANAGEMENT

\begin{tabular}{|c|c|c|c|}
\hline Item Content & Mean & $\underline{\text { SD }}$ & Rank \\
\hline $\begin{array}{l}\text { 13. Establish institutional program entry/completion } \\
\text { requirements }\end{array}$ & $3.78 *$ & 1.01 & 10 \\
\hline 14. Establish student rules \& policies & $4.05^{*}$ & 0.91 & 8 \\
\hline 15. Provide student discipline & $4.32 *$ & 0.95 & 2 \\
\hline 16. Prepare a student handbook & $3.76^{*}$ & 1.13 & 12 \\
\hline $\begin{array}{l}\text { 17. Prepare a master schedule of course/program } \\
\text { offerings }\end{array}$ & $4.08^{*}$ & 1.00 & 7 \\
\hline $\begin{array}{l}\text { 18. Guide staff in selecting \& using effective } \\
\text { strategies }\end{array}$ & $4.49^{*}$ & 0.73 & 1 \\
\hline 19. Direct cooperate education program & $3.77^{*}$ & 0.95 & 11 \\
\hline $\begin{array}{l}\text { 20. Guide staff in integrating technical/vocational } \\
\text { program }\end{array}$ & $4.32 *$ & 0.79 & 2 \\
\hline 21. Promote integration of vocational student activities & $4.02^{*}$ & 0.99 & 9 \\
\hline $\begin{array}{l}\text { 22. Provide technical assistance in customized } \\
\text { training program }\end{array}$ & 3.61 & 1.19 & 14 \\
\hline 23. Direct adult $\&$ continuing education programs & 3.23 & 1.20 & 16 \\
\hline $\begin{array}{l}\text { 24. Guide articulation of post- \& secondary } \\
\text { programs }\end{array}$ & 3.60 & 1.10 & 15 \\
\hline 25. Approve selection of instructional equipment & $4.25^{*}$ & 0.83 & 5 \\
\hline $\begin{array}{l}\text { 26. Approve selection of instructional } \\
\text { supplies/materials }\end{array}$ & $4.32^{*}$ & 0.86 & 2 \\
\hline 27. Provide for student record-keeping system & $4.22^{*}$ & 0.89 & 6 \\
\hline 28. Conduct student orientation activities & 3.26 & 1.21 & 12 \\
\hline
\end{tabular}

*Met criteria for "very important" items. 
In the category of Personnel Management. item 35. conduct staff meetings. with a mean score of 4.49 was perceived as the item of most importance. This was followed by item 32. interview potential staff. with a mean of 4.44 . and item 37 . evaluate staff performance. with a mean of 4.42 . The items of least importance were item 31 , prepare a personnel handbook. with a mean of 3.58: item 30. prepare job descriptions and requirements. with a mean of 3.95 : and item 38 . conduct staff orientation activities. with a mean of 4.16. Nine of the 10 items based on the criteria set by the researcher were perceived by TVE education administrators to be very important. These data are summarized in Table 14.

In the category of Staff Development. TVE administrators indicated that item 39. assess staff development needs. with a mean of 4.48 , was the most important. The least important role was arrange for staff exchanges with business and industry. with a mean of 3.96. All the items in this category met the criteria set by the researcher as perceived by TVE administrators as being very important. These data are summarized in Table 15.

In the category of Professional Relations and Self-Development. TVE administrators perceived that item 44 , develop effective interpersonal skills, with a mean of 4.57 , was the most important. This item was followed by item 52 , assess personal performance as an administrator, with a mean of 4.52 ; and items 47 , participate in professional development activities for self-improvement, and 51, develop cooperative problem-solving and decision-making skills, with a tied mean score of 4.46 . 
TABLE 14

TVE ADMINISTRATORS` PERCEPTION OF THE IMIPORTANCE

OF PERSONNEL MANAGEMENT

\begin{tabular}{lllc}
\hline Item Content & Mean & SD & Rank \\
\hline 29. Assess program staff requirements & $4.33^{*}$ & 0.87 & 4 \\
30. Prepare job description \& requirements & $3.95^{*}$ & 1.04 & 9 \\
31. Prepare a personnel handbook & 3.58 & 1.18 & 10 \\
32. Interview potential staff & $4.44^{*}$ & 0.89 & 2 \\
33. Schedule staff workload & $4.30^{*}$ & 0.93 & 6 \\
34. Provide for staff record-keeping system & $4.18^{*}$ & 0.91 & 7 \\
35. Conduct staff meetings & $4.49^{*}$ & 0.83 & 1 \\
36. Prepare bulletins \& other types of & $4.31^{*}$ & 0.93 & 5 \\
$\quad$ communication & & & 3 \\
37. Evaluate staff performance & $4.42^{*}$ & 0.88 & 3 \\
38. Conduct staff orientation activities & $4.16^{*}$ & 0.91 & 8 \\
\hline
\end{tabular}

*Met criteria for "very important" items.

TABLE 15

TVE ADMINISTRATORS' PERCEPTION OF THE IMPORTANCE OF STAFF DEVELOPMENT

\begin{tabular}{|c|c|c|c|}
\hline Item Content & Mean & $\underline{\text { SD }}$ & Rank \\
\hline 39. Assess staff development needs & $4.48^{*}$ & 0.69 & 1 \\
\hline $\begin{array}{l}\text { 40. Conduct workshops \& other in-service } \\
\text { programs }\end{array}$ & $4.17^{*}$ & 0.93 & 4 \\
\hline 41. Arrange workshops \& in-service programs & $4.32 *$ & 0.82 & 3 \\
\hline 42. Arrange staff exchanges/business/industry & $3.96^{*}$ & 1.06 & 5 \\
\hline 43. Evaluate staff development programs & $4.33^{*}$ & 0.85 & 2 \\
\hline
\end{tabular}

"Met criteria for "very important" items. 
The item perceived by TVE administrators of least importance was item 46. participate in professional organizations other than technical/vocational education. with a mean score of 3.76. All the items in this category based on the criteria set by the researcher were perceived by TVE administrators as very important. These data are summarized in Table 16.

In the category of School/Community Relations. item 59, plan for exhibits and displays, with a mean score of 4.12. was considered to be the most important. Next in importance was item 61, conduct open house activities, with a mean score of 3.77 : and item 53. develop a marketing plan for promoting technical/vocational education, with a mean score of 3.73 . Item 60 , write news releases for school and area media, with a mean score of 3.24 , was the item considered as the least important in the category. Two items in this category were perceived to be very important by TVE administrators, based on the criteria set by the researcher. These data are summarized in Table 17.

In the category Facility and Equipment, the item most highly ranked by TVE administrators was item 67 , comply with health and safety laws and regulations, having a mean score of 4.61 . This was followed by items 68 , direct a safety awareness program with a mean score of 4.34 ; and 69 , establish emergency plans, such as fire and disaster. with a mean score of 4.32 . Item 70 , schedule facility use by community members, was the lowest ranked item in the category. 
TABLE 16

TVE ADMINISTRATORS` PERCEPTION OF THE IMPORTANCE OF PROFESSIONAL RELATIONS AND SELF-DEVELOPMENT

\begin{tabular}{|c|c|c|c|}
\hline Item Content & Mean & $\underline{\mathbf{S D}}$ & Rank \\
\hline 44. Develop effective interpersonal skills & $4.57^{*}$ & 0.67 & 1 \\
\hline $\begin{array}{l}\text { 45. Participate in related professional } \\
\text { organizations }\end{array}$ & $4.25^{*}$ & 0.85 & 7 \\
\hline $\begin{array}{l}\text { 46. Participate in other professional } \\
\text { organizations }\end{array}$ & $3.76^{*}$ & 1.03 & 9 \\
\hline 47. Participate in professional development & $4.46^{*}$ & 0.73 & 3 \\
\hline 48. Model professional image & $4.39 *$ & 0.82 & 5 \\
\hline $\begin{array}{l}\text { 49. Apply information from reputable } \\
\text { professional sources }\end{array}$ & $4.24 *$ & 0.84 & 8 \\
\hline $\begin{array}{l}\text { 50. Apply time management techniques to } \\
\text { personal work }\end{array}$ & $4.38^{*}$ & 0.82 & 6 \\
\hline 51. Develop cooperative problem solving skills & $4.46^{*}$ & 0.75 & 3 \\
\hline $\begin{array}{l}\text { 52. Assess personal performance as } \\
\text { administrator }\end{array}$ & $4.52 *$ & 0.79 & 2 \\
\hline
\end{tabular}

*Met criteria for "very important" items.

Eight of the 10 items in this category, based on the criteria set by the researcher. were perceived to be very important by TVE administrators. These data are summarized in Table 18.

The most important role in the category of Business and Financial Management was item 79, respond to business correspondence, with a mean score of 3.96 . It was 
TABLE 17

TVE ADMINISTRATORS' PERCEPTION OF THE IMPORTANCE OF SCHOOL/COMMUNITY RELATIONS

\begin{tabular}{|c|c|c|c|}
\hline Item Content & Mean & $\underline{\text { SD }}$ & Rank \\
\hline $\begin{array}{l}\text { 53. Develop a marketing plan for promotion of } \\
\text { program }\end{array}$ & 3.73 & 1.16 & 3 \\
\hline 54. Participate in community activities & 3.64 & 1.08 & 6 \\
\hline $\begin{array}{l}\text { 55. Coordinate technical/vocational program } \\
\text { with community }\end{array}$ & 3.62 & 1.08 & 7 \\
\hline $\begin{array}{l}\text { 56. Involve community leaders in school } \\
\text { programs }\end{array}$ & 3.68 & 1.02 & 5 \\
\hline 57. Conduct recognition programs & 3.69 & 1.10 & 4 \\
\hline 58. Make informational presentations to public & 3.44 & 1.15 & 8 \\
\hline 59. Plan exhibits \& displays & $4.12^{*}$ & 1.12 & 1 \\
\hline $\begin{array}{l}\text { 60. Write news releases for school \& area } \\
\text { media }\end{array}$ & 3.24 & 1.12 & 9 \\
\hline 61. Conduct open house activities & $3.77^{*}$ & 1.08 & 2 \\
\hline
\end{tabular}

*Met criteria for "very important" items.

followed by item 76 , analyze the cost of operating various instructional programs. with a mean score of 3.88 ; and item 78 , approve requisitions and work orders, with a mean score of 3.83. The least important was item 72 , establish purchasing and payment procedures, with a mean of 3.43 . Based on the criteria identified by the researcher, five of eight items were perceived to be very important by TVE administrators. These data are summarized in Table 19. 
TABLE 18

TVE ADMINISTRATORS ${ }^{\circ}$ PERCEPTION OF THE IMPORTANCE OF FACILITIES AND EQUIPMENT MANAGEMENT

\begin{tabular}{lllc}
\hline Item Content & Mean & $\underline{\text { SD }}$ & Rank \\
\hline 62. Plan space requirements for program & $4.09^{*}$ & 1.05 & 7 \\
63. Submit building \& equipment specifications & $3.92^{*}$ & 1.23 & 8 \\
64. Develop plan for repair \& maintenance & $4.1^{*}$ & 1.06 & 6 \\
65. Maintain equipment \& supply inventory & $4.30^{*}$ & 1.05 & 5 \\
$\quad$ system & & & \\
66. Establish long-range plan for new acquisitions & $4.32^{*}$ & 0.90 & 4 \\
67. Comply w/ health \& safety laws \& regulations & $4.61^{*}$ & 0.73 & 1 \\
68. Direct safety awareness program & $4.34^{*}$ & 0.89 & 2 \\
69. Establish emergency plans (i.e.. fire \& & $4.32^{*}$ & 0.97 & 3 \\
disaster) & & & \\
70. Schedule community use of facility & 3.28 & 1.22 & 10 \\
71. Prepare renovation \& alteration plans & 3.29 & 1.21 & 9 \\
\hline
\end{tabular}

*Met criteria for "very important" items.

Technical/vocational education administrators, in response to the research question. What do technical/vocational education administrators perceive to be the range of importance in each of the selected roles/functions? indicated that they recognize the role of Professional Relations and Self-Development to be the most important one. They also perceived six of the eight categories of roles to be very important, and viewed the category of School/Community Relations as being of least importance. 
TABLE 19

TVE ADMINISTRATORS` PERCEPTION OF THE IMPORTANCE OF BUSINESS AND FINANCIAL MANAGEMENT

\begin{tabular}{lccc}
\hline Item Content & Mean & SD & Rank \\
\hline 72. Establish purchasing \& paying procedure & 3.43 & 1.30 & 8 \\
73. Prepare budgets & $3.80^{*}$ & 1.24 & 4 \\
74. Administer budgets & 3.75 & 1.23 & 6 \\
$\begin{array}{l}\text { 75. Adopt appropriate tinancial accounting } \\
\text { system }\end{array}$ & $3.79^{*}$ & 1.34 & 5 \\
76. Analyze cost of operating various programs & $3.88^{*}$ & 1.22 & 2 \\
77. Locate funding sources for program & 3.55 & 1.35 & 7 \\
development & & & 3 \\
78. Approve requisition \& work orders & $3.83^{*}$ & 1.29 & 3 \\
79. Respond to business correspondence & $3.96^{*}$ & 1.13 & 1 \\
\hline
\end{tabular}

*Met criteria for "very important" items.

\section{Research Question 2}

Research Question asked: What differences exist among technical/vocational education administrators regarding their perceptions about roles/functions. comparing the variables educational background, tenure in position, and educational setting?

To answer this research question, several hypotheses were tested. Each one is stated, followed by the results of the statistical analyses for that null hypothesis. 


\section{Hypothesis 1}

Hypothesis I stated: There are no significant differences among technical/vocational education administrators about roles/functions on the basis of their educational background.

One-way analysis of variance was performed to test whether there were any significant differences among respondents. The responses used were interval data. The Student Newman Keuls ${ }^{\bullet}$ post hoc multiple comparison test was used to compare group means with an alpha of .05 . Due to the small sample size in some of the groups. a regrouping exercise was performed where the new groups were $<$ B.A.. B.A.. and Graduate.

When one-way analysis of variance was applied in order to determine whether there were any individual roles within the said category that were significantly different. none of the roles were found to be significantly different. The hypothesis was retained for this question. These data are summarized in Table 20 .

\section{Hypothesis 2}

Hypothesis 2 stated: There are no significant differences among technical/vocational education administrators regarding their roles/functions on the basis of tenure in position.

For the purpose of this analysis the groups, based on tenure in position, were collapsed into three categories in order to better facilitate the analysis. The groups were re-classified as, Group 1-Permanent, 2-Appointed, and 3-Other, which included 
TABLE 20

ANOVA FOR EDUCATIONAL BACKGROUND AND TVE ADMINISTRATORS' PERCEIVED IMPORTANCE OF ROLES/FUNCTIONS BY MAJOR CATEGORIES

\begin{tabular}{|c|c|c|c|c|c|c|}
\hline Major Categories & $\begin{array}{l}\text { Educational } \\
\text { Background }\end{array}$ & $\underline{\mathrm{N}}$ & Mean & $\underline{\mathrm{SD}}$ & $\underline{F}$ & $\mathrm{~g}$ \\
\hline Program Planning & $\begin{array}{l}<\text { B.A. } \\
\text { B.A. } \\
\text { Grad. }\end{array}$ & $\begin{array}{l}41 \\
51 \\
23\end{array}$ & $\begin{array}{l}4.21 \\
4.21 \\
4.03\end{array}$ & $\begin{array}{l}.4506 \\
.4901 \\
.7811\end{array}$ & 1.0068 & .3687 \\
\hline $\begin{array}{l}\text { Instructional } \\
\text { Management }\end{array}$ & $\begin{array}{l}<\text { B.A. } \\
\text { B.A. } \\
\text { Grad. }\end{array}$ & $\begin{array}{l}41 \\
51 \\
23\end{array}$ & $\begin{array}{l}3.97 \\
4.03 \\
3.85\end{array}$ & $\begin{array}{l}.5855 \\
.5481 \\
.5703\end{array}$ & 0.7778 & .4619 \\
\hline $\begin{array}{l}\text { Personnel } \\
\text { Management }\end{array}$ & $\begin{array}{l}<\text { B.A. } \\
\text { B.A. } \\
\text { Grad. }\end{array}$ & $\begin{array}{l}41 \\
51 \\
23\end{array}$ & $\begin{array}{l}4.16 \\
4.24 \\
4.29\end{array}$ & $\begin{array}{l}.6143 \\
.7120 \\
.7309\end{array}$ & .3067 & .7365 \\
\hline Staff Development & $\begin{array}{l}<\text { B.A. } \\
\text { B.A. } \\
\text { Grad. }\end{array}$ & $\begin{array}{l}41 \\
51 \\
23\end{array}$ & $\begin{array}{l}4.24 \\
4.30 \\
4.16\end{array}$ & $\begin{array}{l}.5827 \\
.6649 \\
.6549\end{array}$ & .4230 & .6561 \\
\hline $\begin{array}{l}\text { Professional/Self- } \\
\text { Development }\end{array}$ & $\begin{array}{l}<\text { B.A. } \\
\text { B.A. } \\
\text { Grad. }\end{array}$ & $\begin{array}{l}41 \\
51 \\
23\end{array}$ & $\begin{array}{l}4.24 \\
4.40 \\
4.34\end{array}$ & $\begin{array}{l}.6449 \\
.5186 \\
.5579\end{array}$ & .9094 & .4057 \\
\hline $\begin{array}{l}\text { School/Community } \\
\text { Relations }\end{array}$ & $\begin{array}{l}<\text { B.A. } \\
\text { B.A. } \\
\text { Grad. }\end{array}$ & $\begin{array}{l}41 \\
51 \\
23\end{array}$ & $\begin{array}{l}3.57 \\
3.76 \\
3.62\end{array}$ & $\begin{array}{l}.8449 \\
.7933 \\
.7852\end{array}$ & .6555 & .5212 \\
\hline $\begin{array}{l}\text { Facilities \& } \\
\text { Equipment }\end{array}$ & $\begin{array}{l}<\text { B.A. } \\
\text { B.A. } \\
\text { Grad. }\end{array}$ & $\begin{array}{l}41 \\
51 \\
23\end{array}$ & $\begin{array}{l}4.04 \\
4.14 \\
3.92\end{array}$ & $\begin{array}{l}.8033 \\
.6304 \\
.8256\end{array}$ & .6923 & .5025 \\
\hline $\begin{array}{l}\text { Business \& } \\
\text { Financial } \\
\text { Management }\end{array}$ & $\begin{array}{l}<\text { B.A. } \\
\text { B.A. } \\
\text { Grad. }\end{array}$ & $\begin{array}{l}41 \\
51 \\
23\end{array}$ & $\begin{array}{l}3.78 \\
3.80 \\
3.58\end{array}$ & $\begin{array}{c}1.0689 \\
.9070 \\
1.1527\end{array}$ & .3899 & .6781 \\
\hline
\end{tabular}


administrators who were temporary, acting, or other. Some significant differences emerged. Technical/vocational education administrators who were permanently employed and those who were appointed in their job regarded four of the eight categories to be significantly different and recorded a higher mean response than administrators who recorded "other" status.

The categories where there were significant differences were: Instructional Management. School/Community Relations. Facility and Equipment. and Business and Financial Management $(\mathrm{p}<.05)$. Thus the hypothesis was rejected in these four categories. but was retained in the other four. TVE administrators who were permanently employed. and those who were appointed in their job. regarded these four categories to be more important as they recorded a higher mean response than those administrators who were of "other" status. These data are summarized in Table 21.

One-way analysis of variance was used with Student Newman Keuls' post hoc multiple comparison test with an alpha of 0.05 in order to determine which individual roles within the various categories were considered to be significant.

In the category Instructional Management. significant differences were found. These were: Item 15. provide student discipline, $\mathrm{p}=.0097$; item 17, prepare a master schedule of course/program offerings. $p=.0138$; item 18, guide staff in selecting and using effective instructional strategies, $\mathrm{p}=.0114$; and item 20, guide staff in integrating and articulating the technical/vocational program with the total educational program, $p=$ .0289 ; which were all significant at the $p=.05$ level. 
TABLE 21

ANOVA FOR TENURE IN POSITION AND TVE ADMINISTRATORS` PERCEIVED IMPORTANCE OF ROLES/FUNCTIONS BY MAJOR CATEGORIES

\begin{tabular}{|c|c|c|c|c|c|c|}
\hline Major Categories & $\begin{array}{l}\text { Tenure in } \\
\text { Position }\end{array}$ & $\underline{N}$ & Mean & $\underline{\mathrm{SD}}$ & $\underline{E}$ & $\mathrm{p}$ \\
\hline $\begin{array}{l}\text { Program Planning. } \\
\text { Development. \& } \\
\text { Evaluation }\end{array}$ & $\begin{array}{l}\text { Permanent } \\
\text { Appointed } \\
\text { Other }\end{array}$ & $\begin{array}{l}62 \\
33 \\
20\end{array}$ & $\begin{array}{l}4.25 \\
4.14 \\
4.01\end{array}$ & $\begin{array}{l}.5938 \\
.4613 \\
.5078\end{array}$ & 1.5759 & .2114 \\
\hline $\begin{array}{l}\text { Instructional } \\
\text { Management }\end{array}$ & $\begin{array}{l}\text { Permanent } \\
\text { Appointed } \\
\text { Other }\end{array}$ & $\begin{array}{l}62 \\
33 \\
20\end{array}$ & $\begin{array}{l}4.07 \\
4.00 \\
3.62\end{array}$ & $\begin{array}{l}.5543 \\
.4564 \\
.6438\end{array}$ & $5.22+4$ & $.0068^{*}$ \\
\hline $\begin{array}{l}\text { Personnel } \\
\text { Management }\end{array}$ & $\begin{array}{c}\text { Permanent } \\
\text { Appointed } \\
\text { Other }\end{array}$ & $\begin{array}{l}62 \\
33 \\
20\end{array}$ & $\begin{array}{l}4.31 \\
4.19 \\
3.99\end{array}$ & $\begin{array}{l}.61+1 \\
.6798 \\
.8306\end{array}$ & $1.7+25$ & .1798 \\
\hline Staff Development & $\begin{array}{l}\text { Permanent } \\
\text { Appointed } \\
\text { Other }\end{array}$ & $\begin{array}{l}62 \\
33 \\
20\end{array}$ & $\begin{array}{l}4.34 \\
4.19 \\
4.07\end{array}$ & $\begin{array}{l}.5708 \\
.5655 \\
.6124\end{array}$ & 1.6475 & .1972 \\
\hline $\begin{array}{l}\text { Professional } \\
\text { Relations }\end{array}$ & $\begin{array}{l}\text { Permanent } \\
\text { Appointed } \\
\text { Other }\end{array}$ & $\begin{array}{l}62 \\
33 \\
20\end{array}$ & $\begin{array}{l}4.38 \\
4.30 \\
4.25\end{array}$ & $\begin{array}{l}.5708 \\
.5655 \\
.6124\end{array}$ & .4407 & .6447 \\
\hline $\begin{array}{l}\text { School/Community } \\
\text { Relations }\end{array}$ & $\begin{array}{l}\text { Permanent } \\
\text { Appointed } \\
\text { Other }\end{array}$ & $\begin{array}{l}62 \\
33 \\
20\end{array}$ & $\begin{array}{l}3.76 \\
3.72 \\
3.26\end{array}$ & $\begin{array}{l}.7085 \\
.7854 \\
1.0293\end{array}$ & 3.1493 & $.0467^{*}$ \\
\hline $\begin{array}{l}\text { Facilities \& } \\
\text { Equipment }\end{array}$ & $\begin{array}{l}\text { Permanent } \\
\text { Appointed } \\
\text { Other }\end{array}$ & $\begin{array}{l}62 \\
33 \\
20\end{array}$ & $\begin{array}{l}4.15 \\
4.14 \\
3.65\end{array}$ & $\begin{array}{l}.6572 \\
.7038 \\
.8918\end{array}$ & 4.0297 & $.0204^{*}$ \\
\hline $\begin{array}{l}\text { Business \& } \\
\text { Financial } \\
\text { Management }\end{array}$ & $\begin{array}{l}\text { Permanent } \\
\text { Appointed } \\
\text { Other }\end{array}$ & $\begin{array}{l}62 \\
33 \\
20\end{array}$ & $\begin{array}{l}3.87 \\
3.82 \\
3.24\end{array}$ & $\begin{array}{c}1.0217 \\
.8840 \\
1.0729\end{array}$ & 3.2007 & $.0445^{*}$ \\
\hline
\end{tabular}


TABLE 22

ANOVA OF ITEMS IN CATEGORY INSTRUCTIONAL MANAGEMENT

\begin{tabular}{|c|c|c|c|c|}
\hline Item Content & $\begin{array}{l}\text { Tenure in } \\
\text { Position }\end{array}$ & Mean & $\underline{E}$ & $\mathrm{p}$ \\
\hline 15. Provide student discipline & $\begin{array}{l}\text { Permanent } \\
\text { Appointed } \\
\text { Other }\end{array}$ & $\begin{array}{l}4.40 \\
4.51 \\
3.75\end{array}$ & +.8287 & .0097 \\
\hline $\begin{array}{l}\text { 17. Prepare a master schedule of } \\
\text { course/program offerings }\end{array}$ & $\begin{array}{l}\text { Permanent } \\
\text { Appointed } \\
\text { Other }\end{array}$ & $\begin{array}{l}4.21 \\
4.18 \\
3.47\end{array}$ & 4.4512 & .0138 \\
\hline $\begin{array}{l}\text { 18. Guide staff in selecting and using } \\
\text { effective instructional strategies }\end{array}$ & $\begin{array}{l}\text { Permanent } \\
\text { Appointed } \\
\text { Other }\end{array}$ & $\begin{array}{l}4.56 \\
4.61 \\
4.05\end{array}$ & 4.6538 & .0114 \\
\hline $\begin{array}{l}\text { 20. Guide staff in integrating tec/voc. } \\
\text { program with total educational } \\
\text { program. }\end{array}$ & $\begin{array}{l}\text { Permanent } \\
\text { Appointed } \\
\text { Other }\end{array}$ & $\begin{array}{l}4.44 \\
4.34 \\
3.90\end{array}$ & 3.6611 & .0289 \\
\hline
\end{tabular}

In all roles where there was significant difference. TVE administrators who were permanently employed or were appointed in their position recorded a significantly higher mean response than those administrators who were "other." Thus they perceived such roles as being more important. These data are summarized in Table 22.

In the category School/Community Relations, significant differences were found. Item 53, develop a marketing plan for promoting technical/vocational education. $\mathrm{p}=.0260 ;$ item 57 , conduct recognition programs for students, staff, and community supporters, $\mathrm{p}=.0204$, and item 58 , make informational presentations to the public. $\mathrm{p}=$ $.0240 ;$ were all significant at the $\mathrm{p}=.05$ level. 
In all of the items in which there were differences. items 53. 57. and 58. TVE administrators who were permanently employed and those who were appointed in their job recorded a significantly higher mean response than those administrators who were of "other" status. Thus they view this role as being of a greater level of importance than the other group of administrators. These data are summarized in Table 23.

In the category of Facility and Equipment Management. significant differences were found. Item 68. direct a safety-awareness program. $\mathrm{p}=.0103$; item 70 , schedule tacility use by community members. $\mathrm{p}=.0093$ : and item 71 , prepare renovation and alteration plans. $\underline{p}=.0010:$ were all significant at the $\underline{p}=.05$ level.

In all of the items where there were differences. items 68.70 , and 71 . TVE administrators who were permanently employed and those who were appointed in their job recorded a significantly higher mean response than TVE administrators who were of "other" status and thus attached a significantly higher level of importance to this role than TVE administrators who were of "other" status. These data are summarized in Table 24. In the category Business and Financial Management, significant differences were found. Item 75 , adopt an appropriate financial accounting system. $\mathrm{p}=.0389 ;$ and item 78, approve requisitions and work orders, $\mathrm{p}=.0309$; were both significant at the $\mathrm{p}=$ .05 level.

In items 75 and 78 , TVE administrators who were permanently employed and those who were appointed in their job attached a significantly higher level of importance to these roles than TVE administrators who were of "other" status. These data are summarized in Table 25. 
TABLE 23

ANOVA OF ITEMS IN CATEGORY SCHOOL/COMMUNITY RELATIONS

\begin{tabular}{lcccc}
\hline Item Content & $\begin{array}{c}\text { Tenure in } \\
\text { Position }\end{array}$ & Mean & $\underline{F}$ & $\mathrm{p}$ \\
\hline 53. Develop a marketing plan for & Permanent & 3.80 & 3.7752 & .0260 \\
promoting technical/vocational & Appointed & 3.97 & & \\
education & Other & 3.11 & & \\
& Permanent & 3.90 & 4.0328 & .0204 \\
57. Conduct recognition programs & Appointed & 3.64 & & \\
for student. staff \& community & Other & 3.11 & & \\
supporters & Permanent & 3.60 & 3.8566 & .0240 \\
58. Make informational presentations & Appointed & 3.52 & & \\
to the public & Other & 2.79 & & \\
& & & & \\
& & & &
\end{tabular}

\section{Hypothesis 3}

Hypothesis 3 stated: There are no significant differences among technical/vocational education administrators regarding their roles/functions on the basis of educational setting.

For the analysis of this hypothesis, the original five groups were collapsed into three groups with (1) Ministry of Education. (2) tertiary institutions, and (3) vocational centers being regarded as "other" in group 1; Grammar schools as group 2; and Newer secondary schools as group 3.

Significant differences were recorded in five categories. These were, Instructional Management, Personnel Management, Staff Development, 
TABLE 24

ANOVA OF ITEMS IN CATEGORY FACILITIES AND EQUIPMENT

\begin{tabular}{lcccc}
\hline Item Content & $\begin{array}{c}\text { Tenure in } \\
\text { Position }\end{array}$ & Mean & F & p \\
& Permanent & 4.45 & 4.7631 & .0103 \\
68. Direct a safety awareness & Appointed & 4.45 & & \\
program & Other & 3.80 & & \\
& Permanent & 3.49 & 4.8760 & .0093 \\
& Appointed & 3.33 & & \\
70. Schedule facility use by & Other & 2.55 & & \\
community members & Permanent & 3.62 & 7.3459 & .0010 \\
& Appointed & 3.45 & & \\
71. Prepare renovation \& alteration & Other & 2.50 & & \\
plans & & & & \\
& & & &
\end{tabular}

TABLE 25

ANOVA OF ITEMS IN CATEGORY BUSINESS AND FINANCIAL MANAGEMENT

\begin{tabular}{lllll}
\hline Item Content & $\begin{array}{c}\text { Tenure in } \\
\text { Position }\end{array}$ & Mean & E & p \\
& Permanent & 3.92 & 3.3468 & .0389 \\
75. Adopt an appropriate financial & Appointed & 3.97 & & \\
accounting system & Other & 3.10 & & \\
& Permanent & 4.02 & 3.5882 & .0309 \\
& Appointed & 3.88 & & \\
78. Approve requisitions \& work & Other & 3.15 & & \\
orders & & & & \\
& & & & \\
\hline
\end{tabular}


School/Community Relations. and Facilities and Equipment. In all five categories. TVE administrators at Grammar schools in Barbados recorded a significantly lower mean response than their counterparts at the Newer secondary schools and "other" institutions.

It must be noted that TVE administrators at Newer secondary schools and "Other" perceived five of the eight categories to be more important than TVE administrators in the Grammar school setting. When the test of significance was computed. the null hypothesis was rejected for five of the eight categories $(\mathrm{p}=<.05)$. These data are summarized in Table 26.

One-ivay analysis of variance was used with Student Newman Keuls post hoc multiple comparison test with an alpha of .05 in order to determine which roles within the various categories were considered to be significant. Significant differences were found in the categories Instructional Management; Personnel Management: Staff Development: School/Community Relations; and Facilities and Equipment. In the category Instructional Management. significant differences were found. These were item 15. provide student discipline. $\mathrm{p}=.0280$; item 22 , provide technical assistance in the development of customized training project for business and industry, $\mathrm{p}=0010$ : item 23. direct the adult and continuing education program, $\mathrm{p}=.0375$; item 24 , guide in the articulation of secondary and post-secondary technical-vocational education programs, $\mathrm{p}$ $=.0211 ;$ at $\mathrm{p}=<.05$ level.

In item 15, TVE administrators who worked in the Newer secondary schools attached a significantly higher level of importance to the administrative roles than 
TABLE 26

\section{ANOVA FOR EDUCATIONAL SETTING AND TVE ADMINISTRATORS` \\ PERCEIVED IMPORTANCE OF ROLES/FUNCTIONS BY MAJOR CATEGORIES}

\begin{tabular}{|c|c|c|c|c|c|c|}
\hline Major Categories & $\begin{array}{l}\text { Educational } \\
\text { Setting }\end{array}$ & $\underline{N}$ & Mean & $\underline{\mathrm{SD}}$ & $\underline{E}$ & $\mathrm{p}$ \\
\hline $\begin{array}{l}\text { Program Planning, } \\
\text { Development. \& } \\
\text { Evaluation }\end{array}$ & $\begin{array}{l}\text { Other } \\
\text { Grammar } \\
\text { Newer }\end{array}$ & $\begin{array}{l}34 \\
29 \\
51\end{array}$ & $\begin{array}{l}4.28 \\
4.08 \\
4.17\end{array}$ & $\begin{array}{l}.5334 \\
.4730 \\
.5943\end{array}$ & 1.1013 & .3360 \\
\hline $\begin{array}{l}\text { Instructional } \\
\text { Management }\end{array}$ & $\begin{array}{l}\text { Other } \\
\text { Grammar } \\
\text { Newer }\end{array}$ & $\begin{array}{l}34 \\
29 \\
51\end{array}$ & $\begin{array}{l}4.06 \\
3.75 \\
4.07\end{array}$ & $\begin{array}{l}.5458 \\
.6494 \\
.4813\end{array}$ & 3.6778 & $.0284^{*}$ \\
\hline $\begin{array}{l}\text { Personnel } \\
\text { Management }\end{array}$ & $\begin{array}{l}\text { Other } \\
\text { Grammar } \\
\text { Newer }\end{array}$ & $\begin{array}{l}34 \\
29 \\
51\end{array}$ & $\begin{array}{l}4.37 \\
3.84 \\
4.35\end{array}$ & $\begin{array}{l}.6451 \\
.8475 \\
.4901\end{array}$ & 7.2052 & $.0011^{*}$ \\
\hline Statf Development & $\begin{array}{l}\text { Other } \\
\text { Grammar } \\
\text { Newer }\end{array}$ & $\begin{array}{l}34 \\
29 \\
51\end{array}$ & $\begin{array}{l}4.44 \\
3.87 \\
4.33\end{array}$ & $\begin{array}{l}.5581 \\
.7515 \\
.5215\end{array}$ & 7.8951 & $.0006^{*}$ \\
\hline $\begin{array}{l}\text { Professional } \\
\text { Relations \& Self- } \\
\text { Development }\end{array}$ & $\begin{array}{l}\text { Other } \\
\text { Grammar } \\
\text { Newer }\end{array}$ & $\begin{array}{l}34 \\
29 \\
51\end{array}$ & $\begin{array}{l}4.25 \\
4.20 \\
4.48\end{array}$ & $\begin{array}{l}.6713 \\
.6312 \\
.4364\end{array}$ & 2.7772 & .0665 \\
\hline $\begin{array}{l}\text { School/Community } \\
\text { Relations }\end{array}$ & $\begin{array}{l}\text { Other } \\
\text { Grammar } \\
\text { Newer }\end{array}$ & $\begin{array}{l}34 \\
29 \\
51\end{array}$ & $\begin{array}{l}3.87 \\
3.33 \\
3.73\end{array}$ & $\begin{array}{l}.6930 \\
.9024 \\
.7775\end{array}$ & 3.8496 & $.0242 *$ \\
\hline $\begin{array}{l}\text { Facilities \& } \\
\text { Equipment }\end{array}$ & $\begin{array}{l}\text { Other } \\
\text { Grammar } \\
\text { Newer }\end{array}$ & $\begin{array}{l}34 \\
29 \\
51\end{array}$ & $\begin{array}{l}4.13 \\
3.76 \\
4.17\end{array}$ & $\begin{array}{l}.6376 \\
.7863 \\
.7378\end{array}$ & 3.1442 & $.0470^{*}$ \\
\hline $\begin{array}{l}\text { Business \& } \\
\text { Financial } \\
\text { Management }\end{array}$ & $\begin{array}{l}\text { Other } \\
\text { Grammar } \\
\text { Newer }\end{array}$ & $\begin{array}{l}34 \\
29 \\
51\end{array}$ & $\begin{array}{l}3.88 \\
3.75 \\
3.66\end{array}$ & $\begin{array}{l}.9392 \\
1.0474 \\
1.0584\end{array}$ & .4674 & .6279 \\
\hline
\end{tabular}


administrators who worked in "other" or in Grammar schools. In item 22. TVE administrators who worked in "other" institutions and those administrators who worked in Newer secondary schools regarded this role as significantly more important than administrators who worked in Grammar schools.

In items 23 and 24. the mean response of TVE administrators who worked in "other" institutions was significantly higher than those of TVE administrators who worked in Grammar schools and Newer secondary schools. and thus they attached a higher level of importance to their administrative roles than those administrators who worked in the Newer secondary schools and Grammar schools. These data are summarized in Table 27.

In the category Personnel Management significant differences were found. These were item 30. prepare job description and requirements, $p=.0189$ : item 32 . interview potential staff. $\mathrm{p}=.0485$; item 34 , provide for staff record keeping system. $\mathrm{p}=$ .0011 : item 36. prepare bulletins and other communications designed to keep staff informed, $p=.0180 ;$ item 37 , evaluate staff performance, $p=.0007$; and item 38 , conduct staff orientation activities. $\mathrm{p}=.0372$.

In items 30. 32. 34. and 37. TVE administrators who worked at the "other" institutions and those administrators who worked in Newer secondary schools recorded significantly higher mean responses than TVE administrators who worked in Grammar schools. In items 36 and 38, TVE administrators who worked in Newer secondary schools recorded a significantly higher mean response than those TVE administrators who worked in Grammar schools. Technical/vocational education administrators who 
TABLE 27

ANOVA OF ITEMS IN CATEGORY INSTRUCTIONAL MANAGEMENT

\begin{tabular}{lllll}
\hline Item Content & Educational Setting & Mean & $\underline{\mathrm{F}}$ & $\mathrm{p}$ \\
\hline 15. Provide student discipline & Other & 4.1471 & 4.7622 & .0104 \\
& Grammar & 4.0345 & & \\
& Newer & 4.6275 & & \\
& Other & 4.0625 & 7.3837 & .0010 \\
22. Provide technical & Grammar & 2.9655 & & \\
assistance & Newer & 3.6939 & & \\
& Other & 3.6667 & 3.3871 & .0375 \\
23. Direct adult and & Grammar & 2.9286 & & \\
continuing education & Newer & 3.1224 & & \\
program & Other & 4.0294 & 3.9985 & .0211 \\
24. Guide secondary and & Grammar & 3.3214 & & \\
post-secondary & Newer & 3.4694 & & \\
tech/voc. education & & & & \\
program & & & & \\
\hline
\end{tabular}

worked in the Newer secondary schools perceived their role to be of a higher level of importance than those administrators who worked in the Grammar school. These data are summarized in Table 28.

In the category Staff Development, significant differences were found. These were items 39 , assess staff development needs, $p=.0443$; item 40 , conduct workshops and other in-service programs, $\mathrm{p}=.0012$; item 41 , arrange for workshops and in-service programs, and item 42, arrange for staff exchanges with business and industry, $p=.0043$, at the $\mathrm{p}=.05$ level.

In items 39,40 , and 41, TVE administrators who worked in the "other" institutions and in Newer secondary schools recorded significantly higher mean responses 
TABLE 28

ANOVA OF ITEMS IN CATEGORY PERSONNEL MANAGEMENT

\begin{tabular}{|c|c|c|c|c|c|}
\hline & Item Content & $\begin{array}{l}\text { Educational } \\
\text { Setting }\end{array}$ & Mean & $\underline{F}$ & $\mathrm{p}$ \\
\hline 30. & $\begin{array}{l}\text { Prepare job descriptions and } \\
\text { requirements }\end{array}$ & $\begin{array}{l}\text { Other } \\
\text { Grammar } \\
\text { Newer }\end{array}$ & $\begin{array}{l}4.2424 \\
3.5172 \\
4.0208\end{array}$ & 4.1195 & .0189 \\
\hline 32. & Interview potential staff & $\begin{array}{l}\text { Other } \\
\text { Grammar } \\
\text { Newer }\end{array}$ & $\begin{array}{l}4.5294 \\
4.0741 \\
4.5686\end{array}$ & 3.1123 & .0485 \\
\hline 34. & $\begin{array}{l}\text { Provide for a staff record- } \\
\text { keeping system }\end{array}$ & $\begin{array}{l}\text { Other } \\
\text { Grammar } \\
\text { Newer }\end{array}$ & $\begin{array}{l}4.3636 \\
3.6786 \\
4.3878\end{array}$ & 7.2566 & .0011 \\
\hline 36. & $\begin{array}{l}\text { Prepare bulletins and other } \\
\text { communications designed to } \\
\text { keep staff informed }\end{array}$ & $\begin{array}{l}\text { Other } \\
\text { Grammar } \\
\text { Newer }\end{array}$ & $\begin{array}{l}4.3333 \\
3.9630 \\
4.5510\end{array}$ & 4.1763 & .0180 \\
\hline 37. & Evaluate staff performance & $\begin{array}{l}\text { Other } \\
\text { Grammar } \\
\text { Newer }\end{array}$ & $\begin{array}{l}4.6765 \\
3.8966 \\
4.5296\end{array}$ & 7.7909 & .0007 \\
\hline 38. & $\begin{array}{l}\text { Conduct staff orientation } \\
\text { activities }\end{array}$ & $\begin{array}{l}\text { Other } \\
\text { Grammar } \\
\text { Newer }\end{array}$ & $\begin{array}{l}4.2121 \\
3.7931 \\
4.3265\end{array}$ & 3.3950 & .0372 \\
\hline
\end{tabular}


TABLE 29

ANOVA OF ITEMS IN THE CATEGORY STAFF DEVELOPMENT

\begin{tabular}{lllll}
\hline Item Content & $\begin{array}{l}\text { Educational } \\
\text { Setting }\end{array}$ & Mean & F & p \\
& Other & 4.6176 & 3.2078 & .0443 \\
39. Assess staff development & Grammar & 4.2069 & & \\
needs & Newer & 4.5400 & & \\
& Other & 4.2059 & 7.1845 & .0012 \\
40. Conduct workshops and & Grammar & 3.6552 & & \\
other in-service programs. & Newer & 4.4314 & & \\
& Other & 4.3824 & 3.8304 & .0247 \\
41. Arrange for workshops and & Grammar & 3.9655 & & \\
in-service programs & Newer & 4.4694 & & \\
& Other & 4.4242 & 5.7452 & .0043 \\
42. Arrange for staff exchanges & Grammar & 3.5517 & & \\
with business and industry & Newer & 3.9184 & & \\
\hline
\end{tabular}

TABLE 30

ANOVA OF ITEMS IN CATEGORY SCHOOL/COMMUNITY RELATIONS

\begin{tabular}{lllll}
\hline Item Content & $\begin{array}{l}\text { Educational } \\
\text { Setting }\end{array}$ & Mean & E & p \\
\hline 55. Coordinate tech/voc. & Other & 3.8438 & 3.2674 & .0423 \\
education programs with job- & Grammar & 3.1667 & & \\
training programs & Newer & 3.7391 & & \\
58. Make informational & Other & 3.8182 & 4.7490 & .0105 \\
presentations to the public & Grammar & 2.9655 & & \\
& Newer & 3.5098 & & \\
61. Conduct open-house & Other & 4.000 & 3.2785 & .0414 \\
activities & Grammar & 3.4448 & & \\
& Newer & 3.8627 & & \\
\hline
\end{tabular}


than TVE administrators who worked in Grammar schools. Thus TVE administrators who worked in Grammar schools attached the least level of significance to these administrative roles of the three groups of administrators.

In item 62 and item 66. TVE administrators who worked in "other" institutions and those administrators who worked in Newer secondary schools recorded a significantly higher mean score than TVE administrators who worked in Grammar schools. In item 65. TVE administrators who worked in Newer secondary schools recorded a significantly higher mean score than TVE administrators who worked in Grammar schools. In each role of this categor: technical/vocational administrators who worked in Grammar schools attached the least level of importance to these administrative roles. These data are summarized in Table 31.

TABLE 31

ANOVA OF ITEMS IN CATEGORY FACILITIES AND EQUIPMENT

\begin{tabular}{lllll}
\hline Item Content & $\begin{array}{l}\text { Educational } \\
\text { Setting }\end{array}$ & Mean & E & p \\
\hline 62. Plan space requirements & Other & 4.3438 & 3.6937 & .0280 \\
for programs & Grammar & 3.6552 & & \\
& Newer & 4.1569 & & \\
& Other & 4.2727 & 4.9414 & .0088 \\
65. Maintain an equipment and & Grammar & 3.8276 & & \\
supply inventory system & Newer & 4.5686 & & \\
& Other & 4.5152 & 3.3285 & .0395 \\
66. Establish a long-range plan & Grammar & 3.9655 & & \\
for acquisition of new & Newer & 4.3922 & & \\
equipment & & &
\end{tabular}


Although there were no significant differences recorded for the categories Program Planning. Development, and Evaluation: Professional Relations and SelfDevelopment: and Business and Financial Management, items within these categories were found to be significantly different at the $\mathrm{p}=<.05$ level.

In the category Program Planning. Development, and Evaluation. significant difference was found for item 9. recommend curriculum revision. $\mathrm{p}=.0104$. Technical/vocational education administrators who worked in "other" institutions and those administrators who worked in Newer secondary schools recorded a higher mean score than those TVE administrators who worked in Grammar schools.

Technical/vocational education administrators who worked in Newer secondary schools attached the highest level of importance to their roles.

In the category Professional Relations and Self-Development. significant differences were found for item 48 , model professional image through personal appearance and conduct. $\underline{\underline{ }}=.0330$ : and item 52. assess personal performance as an administrator, $\mathrm{p}=.0259$. In item 48. TVE administrators who worked in Newer secondary schools recorded a lower mean score than TVE administrators who worked in "other" institutions. Technical/vocational education administrators of "other" status attached the highest level of importance to this role. In item 52, TVE administrators who worked in Newer secondary schools recorded a lower mean score than administrators who worked in "other" or those administrators who worked in Grammar schools. 
Technical/vocational educational administrators who worked in Grammar schools attached the highest level of importance to this role.

In the category Business and Financial Management. significant differences were found in item 75 . adopt an appropriate financial system. $\mathrm{p}=.0389$ and item 78 . approve requisition and work orders. $\mathrm{p}=.0309$. In both cases. TVE administrators who worked in Newer secondary schools recorded a lower mean score than TVE administrators who worked in the Grammar schools and those of "other" status. These data are summarized in Table 32.

\section{TABLE 32}

ANOVA OF ITEMS IN CATEGORIES PROGRAM PLANNING. DEVELOPMENT. AND EVALUATION: PROFESSIONAL RELATIONS AND SELF-DEVELOPMENT: AND BUSINESS AND FINANCIAL MANAGEMENT

\begin{tabular}{lllll}
\hline Item Content & $\begin{array}{l}\text { Educational } \\
\text { Setting }\end{array}$ & Mean & $\underline{E}$ & p \\
\hline 9. Recommend curriculum & Other & 4.5294 & 4.7622 & .0104 \\
revisions & Grammar & 4.0690 & & \\
& Newer & 4.5800 & & \\
48. Model professional image & Other & 4.5410 & 3.5181 & .0330 \\
through personal appearance & Grammar & 4.3438 & & \\
and conduct & Newer & 4.000 & & \\
52. Assess personal performance & Other & 4.5806 & 3.7758 & .0259 \\
as an administrator & Grammar & 4.6667 & & \\
& Newer & 4.1000 & & \\
75. Adopt an appropriate & Other & 3.9167 & 3.3468 & .0389 \\
financial accounting system & Grammar & 3.9688 & & \\
& Newer & 3.1000 & & \\
& Other & 4.0161 & 3.5882 & .0309 \\
78. Approve requisitions and & Grammar & 3.8788 & & \\
work orders & Newer & 3.1500 & & \\
\hline
\end{tabular}


Hypothesis 3 sought to determine if there were significant difference among TVE administrators regarding their roles/functions on the basis of educational setting. Significant differences were found in five of the eight categories. In all five categories. technical/vocational administrators who worked in "other" institutions and in Newer secondary schools recorded higher mean scores than TVE administrators who worked in Grammar schools and thus they attached a higher level of importance to their roles. In It of 25 items TVE administrators who worked in "other " institutions and those TVE administrators who worked in Newer secondary schools. recorded higher mean responses than TVE administrators who worked in Grammar schools and thus they attached a higher level of importance to their job. In 5 of 25 items. technical/vocational education administrators who worked in "other" institutions recorded higher mean scores than the other two groups of TVE administrators and thus attached the highest level of importance to these roles.

\section{Research Question 3}

Research Question 3 asked: What do technical/vocational education administrators perceive to be their degree of need for further preparation and continuous professional development in each of the selected roles/functions?

The various roles/functions associated with technical/vocational education (TVE) administrators have been organized into the following eight major categories: Program Planning, Development, and Evaluation; Instructional Management; Personnel Management; Staff Development; Professional Relations and Self-Development; 
Schoo/Community Relations: Facilities and Equipment Management: and Business and Financial Management.

Within each major category. technical/vocational education administrators were asked to determine their need for further preparation and continuing professional development. Their responses ranged from "no need" ( 1 on the scale) to "high need" ( 5 on the scale). A given category was considered "no need" if it had a mean score of between 1.00 and 2.50: of "little need" if the mean scores were between 2.51 and 3.75: and "high need" if the mean scores were higher than 3.75 .

Technical/vocational education administrators, on the average. expressed "little need" for further preparation in the major categories of roles/functions. Comparing the eight categories of roles/functions. Staff Development was identified as the category in which TVE administrators had the highest need for further preparation with a mean score of 3.76. Program Planning. Development. and Evaluation was ranked second. with a mean score of 3.70; and Professional Relations and Self-Development was ranked third. with a mean score of 3.59 .

The categories ranked as the lowest need for further preparation were Business and Financial Management, with a mean score of 3.34; followed by Personnel Management, with a mean score of 3.35, and third by the categories Instructional Management and Facilities and Equipment, each with a mean score of 3.43. These data are shown in Table 33.

In the category of Program Planning, Development, and Evaluation, the most important role as perceived by technical/vocational education administrators was item 12 . 
TABLE 33

\section{TVE ADMINISTRATORS' PERCEPTION OF THEIR PERSONAL NEED FOR FURTHER PREPARATION IN ROLES/FUNCTIONS BY MAJOR CATEGORIES}

\begin{tabular}{llll}
\hline Major Categories & Mean & $\underline{\text { SD }}$ & Rank \\
\hline $\begin{array}{l}\text { Program Planning, Development. \& Evaluation (12 } \\
\text { items) }\end{array}$ & 3.70 & 0.78 & 2 \\
Instructional Management (16 items) & 3.43 & 0.87 & 5 \\
& & & \\
Personnel Management (10 items) & 3.35 & 1.07 & 7 \\
Staff Development (5 items) & $3.76^{*}$ & 0.96 & 1 \\
Professional Relations \& Self-Development (9 items) & 3.59 & 0.95 & 4 \\
School/Community Relations (9 items) & 3.66 & 0.91 & 3 \\
Facilities \& Equipment (10 items) & 3.43 & 0.90 & 5 \\
Business \& Financial Management (8 items) & 3.34 & 1.06 & 8 \\
\hline
\end{tabular}

"Met criteria for " high need."

develop supplemental/remedial instructional programs, with a mean score of 3.83. It was followed by item 3, direct course/program planning with a mean score of 3.81 ; and item 9, recommend curriculum revision with a mean score of 3.77 .

The least important role as perceived by the administrators was item 8 , assess student competency, with a mean score of 3.61 ; second, item 1 , survey student interest. and item 11, contract instructional programs, both with a mean score of 3.62 . Based on the criteria set by the researcher, only four items in this category were perceived to be of high need to TVE administrators. These data are summarized in Table 34. 
TABLE 34

TVE ADMINISTRATORS` PERCEPTION OF THEIR PERSONAL NEED FOR FURTHER PREPARATION IN CATEGORY PROGRAM PLANNING. DEVELOPMENT AND EVALUATION

\begin{tabular}{|c|c|c|c|}
\hline Item Content & Mean & $\underline{\mathrm{SD}}$ & Rank \\
\hline 1. Survey student interest & 3.62 & 1.13 & 10 \\
\hline 2. Analyze labor demand data & 3.70 & $\mathrm{l} .04$ & 6 \\
\hline 3. Direct course/program planning & $3.81^{*}$ & 0.96 & 2 \\
\hline 4. Prepare an annual plan & 3.68 & 1.03 & 7 \\
\hline 5. Prepare a $3-5$ year plan & 3.65 & 1.03 & 9 \\
\hline 6. Conduct course/program reviews & 3.68 & 1.07 & 7 \\
\hline 7. Conduct student follow-up studies & 3.61 & 1.07 & 12 \\
\hline 8. Assess student competency & 3.72 & 1.05 & 5 \\
\hline 9. Recommend curriculum revisions & $3.77^{*}$ & 1.14 & 3 \\
\hline $\begin{array}{l}\text { 10. Write proposals for the funding of new } \\
\text { programs }\end{array}$ & $3.76^{*}$ & L.07 & 4 \\
\hline 11. Contract instructional programs & 3.62 & 1.13 & 10 \\
\hline $\begin{array}{l}\text { 12. Develop supplemental/remedial instructional } \\
\text { programs }\end{array}$ & $3.83^{*}$ & 1.09 & 1 \\
\hline
\end{tabular}

*Met criteria for "high need" item.

For the category of Instructional Management, the area of highest need for further preparation was item 20 , guide staff in integrating and articulating technical/vocational program, with a mean score of 3.80 ; followed by item 18 , guide staff in selecting and using effective instructional strategies, with a mean score of 3.72 ; and 
item 22. provide technical assistance in the development of customized training programs with a mean score of 3.70 .

Technical/vocational education administrators regarded item 16. prepare a student handbook. with a mean score of 3.09 , as being the one of least need. Second was item 28. conduct student orientation activities. with a mean score of 3.15. and third. item 14. establish student rules and policies with a mean score of 3.19. Based on the criteria identified by the researcher. only 1 of the 16 items in the category was perceived to be of "high need" for training by TVE administrators. These data are summarized in Table 35.

In the category of Personnel Management. the individual role in which TVE administrators perceived the most need for further preparation was item 37 , evaluate staff development, with a mean score of 3.69 . It was followed by item 29 , assess program staffing requirements, with a mean score of 3.51 , and item 32 , interview potential staff. The individual roles with the least need for further preparation were items 33 . schedule staff work load. and 35 , conduct staff meetings, with a tied mean score of 3.18 . These data are summarized in Table 36.

None of the roles in the category of Personnel Management were regarded by TVE administrators as being of "high need." In the present bureaucratic system of Barbados, Personnel Functions are usually performed by the institution's Board of Management in conjunction with the Ministry of Education. Thus TVE administrators might not have seen the need for further preparation in this area as this category might have been perceived as outside their domain. 
TABLE 35

TVE ADMINISTRATORS` PERCEPTION OF THEIR PERSONAL NEED FOR FURTHER PREPARATION IN CATEGORY INSTRUCTIONAL MANAGEMENT

\begin{tabular}{|c|c|c|c|}
\hline Item Content & Mean & $\underline{\mathrm{SD}}$ & Rank \\
\hline 13. Establish instructional program entry & 3.40 & 1.10 & 10 \\
\hline 14. Establish student rules $\&$ policies & 3.19 & 1.28 & 14 \\
\hline 15. Provide student discipline & 3.21 & 1.36 & 13 \\
\hline 16. Prepare a student handbook & 3.09 & 1.34 & 16 \\
\hline $\begin{array}{l}\text { 17. Prepare a master schedule of course program } \\
\text { offerings }\end{array}$ & 3.48 & 1.28 & 8 \\
\hline 18. Guide staff in selecting $\&$ using strategies & 3.72 & 1.03 & 2 \\
\hline 19. Direct the cooperative education program & 3.65 & 1.05 & 4 \\
\hline $\begin{array}{l}\text { 20. Guide staff in integrating \& articulating the } \\
\text { technical/vocational program. }\end{array}$ & $3.80^{*}$ & 1.01 & 1 \\
\hline $\begin{array}{l}\text { 21. Promote the integration of vocational student } \\
\text { organizational activities }\end{array}$ & 3.63 & 1.07 & 5 \\
\hline $\begin{array}{l}\text { 22. Provide technical assistance in the development } \\
\text { of customized training }\end{array}$ & 3.70 & 1.04 & 3 \\
\hline $\begin{array}{l}\text { 23. Direct the adult \& continuing education } \\
\text { programs }\end{array}$ & 3.22 & 1.29 & 12 \\
\hline $\begin{array}{l}\text { 24. Guide the articulation of secondary \& post- } \\
\text { secondary programs }\end{array}$ & 3.62 & 1.09 & 6 \\
\hline 25. Approve selection of instructional equipment & 3.51 & 1.19 & 7 \\
\hline 26. Approve selection of instructional supplies & 3.46 & 1.17 & 9 \\
\hline 27. Provide for a student record-keeping system & 3.35 & 1.34 & 11 \\
\hline 28. Conduct student orientation & 3.15 & 1.31 & 15 \\
\hline
\end{tabular}

* Met criteria for "high need" item. 
In the category Staff Development. TVE administrators perceived item 43. evaluate staff development programs. with a mean score of 3.87 as the most needed for further preparation. Second was item 40 , conduct workshops and other in-service

\section{TABLE 36}

TVE ADMINISTRATORS' PERCEPTION OF THEIR PERSONAL NEED FOR FURTHER PREPARATION IN CATEGORY PERSONNEL MANAGEMENT

\begin{tabular}{llll}
\hline Item Content & Mean & $\underline{\text { SD }}$ & Rank \\
\hline 29. Assess program staffing requirements & 3.51 & 1.18 & 2 \\
30. Prepare job descriptions \& requirement & 3.41 & 1.17 & 4 \\
31. Prepare a personnel handbook & 3.31 & 1.28 & 6 \\
32. Interview potential staff & 3.42 & 1.36 & 3 \\
33. Schedule staff workloads & 3.18 & 1.36 & 9 \\
34. Provide for a staff record-keeping system & 3.39 & 1.32 & 5 \\
35. Conduct staff meetings & 3.18 & 1.44 & 9 \\
36. Prepare bulletins \& other communications & 3.23 & 1.38 & 8 \\
37. Evaluate staff performance & 3.69 & 1.29 & 1 \\
38. Conduct staff orientation activities & 3.37 & 1.28 & 7 \\
\hline
\end{tabular}

programs, with a mean score of 3.82 , and third, item 39 . assess staff-development needs. with a mean score of 3.78 .

The individual role with the least perceived need for additional preparation, in the category of Staff Development, was item 42, arrange for staff exchanges, with a mean score of 3.60 , followed by item 41 , arrange for workshops and in-service programs, with 
a mean score of 3.70 . Three of the five items in the category met the criteria of "high need“ for additional preparation. These data are summarized in Table 37.

\section{TABLE 37}

TVE ADMINISTRATORS' PERCEPTION OF THEIR PERSONAL NEED FOR FURTHER PREPARATION IN CATEGORY STAFF DEVELOPMENT

\begin{tabular}{llll}
\hline Item Content & Mean & $\underline{\text { SD }}$ & Rank \\
\hline 39. Assess staff-development needs & $3.78^{*}$ & 1.07 & 3 \\
40. Conduct workshops \& other in-service programs & $3.82^{*}$ & 1.11 & 2 \\
41. Arrange for workshops \& in-service programs & 3.70 & 1.17 & 4 \\
42. Arrange for staff exchanges & 3.69 & 1.25 & 5 \\
43. Evaluate staff-development programs & $3.87^{*}$ & 1.03 & 1 \\
\hline
\end{tabular}

*Met criteria for "high need" item.

For the category of Professional Relations and Self-Development. TVE administrators perceived the individual role. item 52 , assess personal performance as an administrator, with a mean score of 3.80 , as the one most needed for additional preparation. This role was the only one of the nine that they considered to be of "high need."

The individual roles in which TVE administrators expressed the least need for further preparation were item 48, model professional image through personal appearance and conduct, with a mean score of 3.25 ; item 46 , participate in professional organization other than technical/vocational education, with a mean score of 3.35 ; and item 45 , 
participate in professional organization related to technical/vocational. with a mean score of 3.55 . These data are summarized in Table 38 .

\section{TABLE 38}

TVE ADMINISTRATORS' PERCEPTION OF THEIR PERSONAL NEED FOR FURTHER PREPARATION IN CATEGORY PROFESSIONAL RELATIONS AND SELF-DEVELOPMENT

\begin{tabular}{llll}
\hline Item Content & Mean & SD & Rank \\
\hline 44. Develop effective interpersonal skills & 3.70 & 1.22 & 4 \\
$\begin{array}{l}\text { 45. Participate in professional organizations } \\
\text { related to technical/vocational education }\end{array}$ & 3.55 & 1.17 & 7 \\
$\begin{array}{l}\text { 46. Participate in professional organizations } \\
\text { other than technical/vocational education }\end{array}$ & 3.35 & 1.19 & 8 \\
$\begin{array}{l}\text { 47. Participate in professional development activities } \\
\text { 48. Model professional image through personal }\end{array}$ & 3.74 & 1.15 & 2 \\
$\begin{array}{l}\text { appearance \& conduct } \\
\text { 49. Apply information from professional journals }\end{array}$ & 3.57 & 1.21 & 9 \\
$\begin{array}{l}\text { 50. Apply time-management techniques to } \\
\text { personal work assignments }\end{array}$ & 3.62 & 1.20 & 5 \\
$\begin{array}{l}\text { 51. Develop cooperative problem solving } \\
\text { 52. Assess personal performance as an administrator }\end{array}$ & $3.80 *$ & 1.09 & 1 \\
\hline
\end{tabular}

"Met criteria for "high needs" item.

There is the perennial debate in Barbados as to whether teaching is classified as one of the professions. TVE administrators seemed to be caught up in the milieu as they expressed only a moderate need for further professional development. It might also be perceived that the traditional professional image is not attractive to TVE administrators as 
might be reflected in their response to item 48 . model professional image through appearance and conduct.

For the category of School/Community Relations TVE administrators did not perceive any role to be of "high need" based on the criteria set. They expressed a moderate need for all roles. The highest ranked item was item 53, develop a marketing plan for promoting technical/vocational education. with a mean score of 3.68 . followed by item 57 . conduct recognition programs for students. staff. and community supporters. with a mean score of 3.49 : and item 59, plan for exhibit and displays. with a mean score of 3.39 .

The individual roles in which TVE administrators perceived they needed the least additional preparation were items 60 , write news releases for school and area media. with a mean score of 3.17 ; item 58 . make informational presentations to the public. with a mean score of 3.19; and item 54, participate in community activity, with a mean score of 3.21. These data are sumnarized in Table 39.

In the category of Facilities and Equipment, TVE administrators did not perceive any role to be of "high need" based on the criteria set by the researcher. A moderate need was expressed for most roles in this category. These range from items 67. comply with health and safety laws and regulations, and 69, establish emergency plan (such as fire and disaster), with a tied mean score of 3.69; to the least role, item 70 , schedule facility use by community members, with a mean score of 2.91 . These data are summarized in Table 40. 
For the category of business and financial management. the individual roles in which TVE administrators perceived the most need for further preparation were item 76 . analyze the cost of operating various instructional programs. with a mean score of 3.60 : item 77, locate sources of funds for program development and operation, with a mean score of 3.53. and items 74, administer budgets, and 75, adopt an appropriate financial accounting system. both with a mean score of 3.42 .

TABLE 39

TVE ADMINISTRATORS' PERCEPTION OF THEIR PERSONAL NEED FOR FURTHER PREPARATION IN CATEGORY SCHOOL/COMMUNITY RELATIONS

\begin{tabular}{|c|c|c|c|}
\hline Item Content & Mean & $\underline{\mathrm{SD}}$ & Rank \\
\hline 53. Develop a marketing plan & 3.68 & 1.12 & l \\
\hline 54. Participate in community activities & 3.21 & 1.12 & 7 \\
\hline $\begin{array}{l}\text { 55. Coordinate technical/vocational education programs } \\
\text { with other community job training }\end{array}$ & 3.37 & 1.12 & 4 \\
\hline 56. Involve community leaders & 3.36 & 1.14 & 5 \\
\hline 57. Conduct recognition programs for students & 3.49 & 1.17 & 2 \\
\hline 58. Make information presentations to the public & 3.19 & 1.24 & 8 \\
\hline 59. Plan for exhibits and displays & 3.39 & 1.13 & 3 \\
\hline 60. Write news releases for school and area media & 3.17 & 1.14 & 9 \\
\hline 61. Conduct open-house activities & 3.29 & 1.15 & 6 \\
\hline
\end{tabular}

Technical/vocational education administrators perceived item 79 , respond to business correspondence, with a mean score of 3.10 , to be the individual role of least need for further preparation. Second was item 78, approve requisition and work orders, 
with a mean score of 3.15 ; and third, item 72. establish purchasing and payment procedure. with a mean score of 3.23 .

None of the roles in this category of Business and Financial management met the criteria set by the researcher for "high need." TVE administrators in Barbados regard

TABLE 40

TVE ADMINISTRATORS' PERCEPTION OF THEIR PERSONAL NEED FOR FURTHER PREPARATION IN CATEGORY FACILITIES AND EQUIPMENT

\begin{tabular}{|c|c|c|c|}
\hline Item Content & Mean & $\underline{\mathrm{SD}}$ & Rank \\
\hline 62. Plan space requirements for programs & 3.42 & 1.20 & 6 \\
\hline 63. Submit building and equipment specifications & 3.38 & 1.16 & 7 \\
\hline $\begin{array}{l}\text { 64. Develop a plan for repair and maintenance of } \\
\text { equipment \& facilities }\end{array}$ & 3.43 & 1.20 & 5 \\
\hline $\begin{array}{l}\text { 65. Maintain an equipment and supply inventory } \\
\text { system }\end{array}$ & 3.32 & 1.25 & 8 \\
\hline $\begin{array}{l}\text { 66. Establish a long-range plan for acquisition of } \\
\text { new equipment }\end{array}$ & 3.52 & 1.13 & 4 \\
\hline $\begin{array}{l}\text { 67. Comply with heaith and safety laws and } \\
\text { regulations }\end{array}$ & 3.69 & 1.16 & 1 \\
\hline 68. Direct a safety-awareness program & 3.67 & 1.14 & 3 \\
\hline 69. Establish emergency plans & 3.69 & 1.23 & 2 \\
\hline 70. Schedule facility use by community members & 2.91 & 1.23 & 10 \\
\hline 71. Prepare renovation and alteration plans & 3.22 & 1.23 & 9 \\
\hline
\end{tabular}

further training in this function to be of little need as it might not be perceived as part of their job. These data are summarized in Table 41. 
TABLE 41

TVE ADMINISTRATORS' PERCEPTION OF THEIR PERSONAL NEED FOR FURTHER PREPARATION IN CATEGORY BUSINESS AND FINANCIAL MANAGEMENT

\begin{tabular}{llll}
\hline Item Content & Mean & $\underline{\text { SD }}$ & Rank \\
\hline 72. Establish purchasing and payment procedures & 3.23 & 1.31 & 6 \\
73. Prepare budgets & 3.33 & 1.31 & 5 \\
74. Administer budgets & 3.42 & 1.25 & 3 \\
75. Adopt an appropriate financial accounting system & 3.42 & 1.27 & 3 \\
76. Analyze the cost of operating various & 3.60 & 1.24 & 1 \\
$\quad$ instructional programs & & & \\
77. Locate sources of funds for program development & 3.53 & 1.33 & 2 \\
$\quad$ and operation & & & \\
78. Approve requisitions and work orders & 3.15 & 1.33 & 7 \\
79. Respond to business correspondence & 3.10 & 1.29 & 8 \\
\hline
\end{tabular}

\section{Research Question 4}

Research Question 4 asked: What differences exist among technical/vocational education administrators regarding their professional development needs. comparing the variable of educational background, tenure in position, and educational setting?

To answer this research question, three hypotheses were tested. Each one is stated. followed by the results of the statistical analysis for that null hypothesis.

\section{Hypothesis 4}


Hypothesis 4 stated: There is no significant difference among technical/vocational education administrators regarding their professional development needs on the basis of educational background.

A one-way analysis of variance was performed in order to test whether there were any significant differences among the groups of respondents. Respondents who had "O." "A" or diplomas were placed in group 1 : respondents with B.A. degrees were placed in group 2: and those with M.A .or Ph.D. degrees were placed in group 3 (graduate).

In two major categories. significant differences were recorded. They were. program planning. development, and evaluation: and instructional management: $(\mathrm{p}=$ $<.05$ ). In both the categories of Program Planning, Development, and Evaluation: and Instructional Management, administrators with less than a B.A. and B.A. degrees recorded a significantly higher mean response than those administrators with graduate degrees. The null hypothesis was rejected in these two categories and retained in the other six categories.

It must be noted that in all cases where there were differences. the mean responses of administrators with less than a B.A. and those with B.A. degrees were higher than those of administrators with graduate degree status. This demonstrated that administrators with a B.A. or less than a B.A. perceived a higher need for additional preparation in all categories than those administrators with graduate degrees. These data are summarized in Table 42. 
TABLE 42

ANOVA FOR EDUCATIONAL BACKGROUND AND TVE ADMINISTRATORS' PERCEIVED NEED FOR PROFESSIONAL DEVELOPMENT BY MAJOR CATEGORIES

\begin{tabular}{|c|c|c|c|c|c|c|}
\hline Major Category & $\begin{array}{l}\text { Educational } \\
\text { Background }\end{array}$ & $\underline{N}$ & Mean & $\underline{\mathrm{SD}}$ & $\underline{F}$ & $\underline{p}$ \\
\hline $\begin{array}{l}\text { Program Planning, } \\
\text { Development. \& } \\
\text { Evaluation }\end{array}$ & $\begin{array}{l}<\text { B.A. } \\
\text { B.A. } \\
\text { Grad }\end{array}$ & $\begin{array}{l}41 \\
51 \\
23\end{array}$ & $\begin{array}{l}3.82 \\
3.77 \\
3.33\end{array}$ & $\begin{array}{l}.6906 \\
.6623 \\
1.0454\end{array}$ & 3.3961 & $.0370^{*}$ \\
\hline $\begin{array}{l}\text { Instructional } \\
\text { Management }\end{array}$ & $\begin{array}{l}<\text { B.A. } \\
\text { B.A. } \\
\text { Grad }\end{array}$ & $\begin{array}{l}41 \\
51 \\
23\end{array}$ & $\begin{array}{l}3.57 \\
3.52 \\
2.99\end{array}$ & $\begin{array}{l}.8165 \\
.7493 \\
1.0937\end{array}$ & 3.9331 & $.0223 *$ \\
\hline $\begin{array}{l}\text { Personnel } \\
\text { Management }\end{array}$ & $\begin{array}{l}<\text { B.A. } \\
\text { B.A. } \\
\text { Grad }\end{array}$ & $\begin{array}{l}41 \\
51 \\
23\end{array}$ & $\begin{array}{l}3.44 \\
3.41 \\
3.03\end{array}$ & $\begin{array}{l}.9679 \\
1.0134 \\
1.3417\end{array}$ & 1.2539 & .2894 \\
\hline Staff Development & $\begin{array}{l}<\text { B.A. } \\
\text { B.A. } \\
\text { Grad }\end{array}$ & $\begin{array}{l}41 \\
51 \\
23\end{array}$ & $\begin{array}{l}3.90 \\
3.84 \\
3.33\end{array}$ & $\begin{array}{l}.8528 \\
.8941 \\
1.1811\end{array}$ & 3.0277 & .0524 \\
\hline $\begin{array}{l}\text { Professional Relations } \\
\& \text { Self-Development }\end{array}$ & $\begin{array}{l}<\text { B.A. } \\
\text { B.A. } \\
\text { Grad }\end{array}$ & $\begin{array}{l}41 \\
51 \\
23\end{array}$ & $\begin{array}{l}3.59 \\
3.70 \\
3.35\end{array}$ & $\begin{array}{l}.9426 \\
.9342 \\
.9719\end{array}$ & 1.0911 & .3394 \\
\hline $\begin{array}{l}\text { School/Community } \\
\text { Relations }\end{array}$ & $\begin{array}{l}<\text { B.A. } \\
\text { B.A. } \\
\text { Grad }\end{array}$ & $\begin{array}{l}41 \\
51 \\
23\end{array}$ & $\begin{array}{l}3.29 \\
3.53 \\
3.03\end{array}$ & $\begin{array}{l}.9651 \\
.8589 \\
.8700\end{array}$ & 2.5954 & .0791 \\
\hline $\begin{array}{l}\text { Facilities \& } \\
\text { Equipment }\end{array}$ & $\begin{array}{l}<\text { B.A. } \\
\text { B.A.. } \\
\text { Grad }\end{array}$ & $\begin{array}{l}41 \\
51 \\
23\end{array}$ & $\begin{array}{l}3.423 \\
.59 \\
3.08\end{array}$ & $\begin{array}{l}.9399 \\
.7767 \\
1.0295\end{array}$ & 2.6376 & .0760 \\
\hline $\begin{array}{l}\text { Business \& Financial } \\
\text { Management }\end{array}$ & $\begin{array}{l}<\text { B.A. } \\
\text { B.A. } \\
\text { Grad }\end{array}$ & $\begin{array}{l}41 \\
51 \\
23\end{array}$ & $\begin{array}{l}3.23 \\
3.54 \\
3.13\end{array}$ & $\begin{array}{l}1.1289 \\
.9504 \\
1.1278\end{array}$ & 1.5868 & .2091 \\
\hline
\end{tabular}


One-way analysis of variance was used with Student Newman Keuls` post hoc multiple comparison test with an alpha of 0.05 in order to determine which roles within the various categories were considered to be significant. Significant difference were found.

In the category Program Planning. Development. and Evaluation. significant differences were found. Item 7. conduct student follow-up studies. $\mathrm{p}=.0126$ : item 8 . assess student competency and grading procedures. $\mathrm{p}=.0323$ : item 9. Recommend curriculum revisions. $\mathrm{p}=.0019$ were all significant at the $\mathrm{p}=.05$ level. In item 7 and item 9. TVE administrators whose qualifications were less than a B.A. expressed a significantly higher need for further preparation than Group 3. administrators who had graduate status, or Group 2, administrators who had B.A. degrees.

In item 8. TVE administrators whose qualifications were less than a B.A. expressed a significantly higher need for further preparation than TVE administrators who had graduate status. These data are summarized Table 43.

In the category Instructional Management, significant differences were found. Item 14, establish student rules and policies, $\mathrm{p}=.0483$; item 28 , conduct student orientation activities. were significant at the $\mathrm{p}=<.05$ level.

In item 14, TVE administrators whose qualifications were less than a B.A., expressed a significantly higher need for further preparation than TVE administrators who had graduate status. In item 28 , the mean response of TVE administrators whose qualifications were less than a B.A. or a B.A. were significantly higher than TVE administrators of graduate status. These data are summarized in Table 44. 
Although there were no significant differences found in the categories Staff Development. Professional Relations and Self-Development. School/Community Relations, Facilities and Equipment Management. and Business and Financial Management. items within these categories were found to be significantly different. In the category Professional Relations and Self-Development. significant difference was found in item 45 , participate in professional organizations related to technical/vocational education. TVE administrators with graduate degrees experienced less need for further preparation than TVE administrators with a B.A. or less than a B.A. degree.

\section{TABLE 43}

ANOVA OF ITEMS IN CATEGORY PROGRAM PLANNING. DEVELOPMENT. AND EVALUATION

\begin{tabular}{lllll}
\hline Item Content & $\begin{array}{l}\text { Educational } \\
\text { Background }\end{array}$ & Mean & $\underline{\mathrm{F}}$ & $\mathrm{p}$ \\
\hline 7. Conduct student follow-up & <B.A. & 4.02 & 4.5504 & .0126 \\
studies & B.A. & 3.71 & & \\
& Grad. & 3.48 & & \\
8. Assess student competency \& & <B.A. & 3.97 & 3.5469 & .0323 \\
grading procedures & B.A. & 3.79 & & \\
& Grad. & 3.31 & & \\
9. Recommend curriculum & <B.A. & 4.23 & 6.6247 & .0019 \\
revisions & B.A. & 3.73 & & \\
& Grad. & 3.30 & & \\
\hline
\end{tabular}

In the category School/Community Relations, significant difference was found in item 61 , conduct open-house activities, $\mathrm{p}=.0149$. TVE administrators with graduate 
degrees expressed less need for further preparation than TVE administrators with B.A. degrees. In the category Facilities and Equipment significant difference was found in item 68. direct a safety awareness program. $p=.0302$. TVE administrators with graduate degrees expressed significantly less need for further preparation than administrators with B.A. degrees. In the category Business and Financial Management, significant difference was found in item 77 , locate sources of funds for program development and operation. $p$ $=.0203$. TVE administrators with less than a B.A. degree expressed less need for further preparation than TVE administrators with B.A. degrees. These data are summarized in Table 45 .

TABLE 44

ANOVA OF ITEMS IN CATEGORY INSTRUCTIONAL MANAGEMENT

\begin{tabular}{lllll}
\hline \multicolumn{1}{c}{ Item Content } & $\begin{array}{l}\text { Educational } \\
\text { Background }\end{array}$ & Mean & $\underline{\mathrm{F}}$ & $\mathrm{p}$ \\
\hline 14. Establish student rules \& & <B.A. & 3.46 & 3.1138 & .0483 \\
policies & B.A. & 3.22 & & \\
& Grad & 2.65 & & \\
28. Conduct student & <B.A. & 3.29 & 3.9436 & .0221 \\
orientation activities & BA & 3.33 & & \\
& Grad. & 2.48 & & \\
\hline
\end{tabular}

In the analysis of hypothesis 4 , significant differences were found for four items. TVE administrators with less than a B.A. degree expressed a greater need for further preparation than administrators with B.A. or graduate degrees. In 5 of 11 items, 
TVE administrators with less than a B.A. degree expressed a greater need for further preparation than both TVE administrators with a B.A.. or those with graduate degrees.

\section{Hypothesis $\mathbf{5}$}

Hypothesis 5 stated: There are no significant differences among technical/vocational educations administrators regarding their professional development needs on the basis of tenure in position.

TABLE 45

ANOVA OF ITEMS IN CATEGORIES PROFESSIONAL RELATIONS AND SELFDEVELOPMENT; SCHOOL/COMMUNITY RELATIONS;

FACILITIES AND EQUIPMENT: AND BUSINESS AND FINANCIAL MANAGEMENT

\begin{tabular}{lllll}
\hline Item Content & $\begin{array}{l}\text { Educational } \\
\text { Background }\end{array}$ & Mean & E & $\mathrm{p}$ \\
\hline 45. Participate in professional & <B.A. & 3.6500 & 4.7186 & .0108 \\
organizations related to & B.A. & 3.7647 & & \\
tech/voc. education & Grad & 2.9130 & & \\
61. Conduct open-house & <B.A. & 3.1951 & 4.3706 & .0149 \\
activities & B.A. & 3.5882 & & \\
& Grad. & 2.7826 & & \\
68. Direct a safety-awareness & <B.A. & 3.7073 & 3.6111 & .0302 \\
program & B.A. & 3.8824 & & \\
& Grad. & 3.1304 & & \\
77. Locate sources of funds for & <B.A. & 3.1500 & 4.0383 & .0203 \\
program development and & B.A. & 3.9020 & & \\
operation & Grad. & 3.3478 & & \\
\hline
\end{tabular}


One-way analysis of variance procedure was used to determine whether there were any significant differences among TVE administrators regarding their professional development needs on the basis of tenure in position. No statistically significant differences were found among the three groups of TVE administrators $(p=<.05)$ with regard to their perception of their need for further preparation within the eight major categories. Thus the null hypothesis of no significant differences was retained. These data are summarized in Table 46.

Although significant differences were not found in the category Program Planning. Development, and Evaluation, and in the category Instructional Management. some items within these categories were significantly different. Significant difference was found in the category Program Planning, Development, and Evaluation in item 9. recommend curriculum revisions. $\mathrm{p}=.0116$. TVE administrators who were of "other" status expressed less need for further preparation than TVE administrators who were permanently employed or those administrators who were appointed in their job.

In the category Instructional Management, significant differences were found in item 15, provide student discipline, $\mathrm{p}=.0211$; and item 25, approve selection of instructional equipment, $\mathrm{p}=.0327$. In both cases TVE administrators who were of "other" status (acting or temporary employed) expressed the least need for further preparation when compared with administrators who were permanently employed or those administrators who were permanently appointed in their job. These data are summarized in Table 47. 
TABLE 46

ANOVA FOR TENURE IN POSITION AND TVE ADMINISTRATORS' PERCEIVED NEED FOR PROFESSIONAL DEVELOPMENT BY MAJOR CATEGORIES

\begin{tabular}{|c|c|c|c|c|c|c|}
\hline Major Categories & $\begin{array}{l}\text { Tenure in } \\
\text { Position }\end{array}$ & $\underline{N}$ & Mean & $\underline{\mathrm{SD}}$ & $\underline{E}$ & $\mathrm{p}$ \\
\hline $\begin{array}{l}\text { Program Planning. } \\
\text { Development. \& } \\
\text { Evaluation }\end{array}$ & $\begin{array}{l}\text { Permanent } \\
\text { Appointed } \\
\text { Other }\end{array}$ & $\begin{array}{l}62 \\
33 \\
20\end{array}$ & $\begin{array}{l}3.71 \\
3.83 \\
3.46\end{array}$ & $\begin{array}{l}.8672 \\
.6397 \\
.6609\end{array}$ & 1.4374 & .2419 \\
\hline $\begin{array}{l}\text { Instructional } \\
\text { Management }\end{array}$ & $\begin{array}{l}\text { Permanent } \\
\text { Appointed } \\
\text { Other }\end{array}$ & $\begin{array}{l}62 \\
33 \\
20\end{array}$ & $\begin{array}{l}3.50 \\
3.49 \\
3.12\end{array}$ & $\begin{array}{l}.9868 \\
.6410 \\
.7877\end{array}$ & 1.5973 & .2070 \\
\hline Personnel Management & $\begin{array}{l}\text { Permanent } \\
\text { Appointed } \\
\text { Other }\end{array}$ & $\begin{array}{l}62 \\
33 \\
20\end{array}$ & $\begin{array}{l}3.48 \\
3.21 \\
3.16\end{array}$ & $\begin{array}{l}1.1849 \\
.8323 \\
1.0532\end{array}$ & 1.0492 & .3536 \\
\hline Staff Development & $\begin{array}{l}\text { Permanent } \\
\text { Appointed } \\
\text { Other }\end{array}$ & $\begin{array}{l}62 \\
33 \\
20\end{array}$ & $\begin{array}{l}3.82 \\
3.87 \\
3.39\end{array}$ & $\begin{array}{l}1.0801 \\
.7561 \\
.8069\end{array}$ & 1.8198 & .1668 \\
\hline $\begin{array}{l}\text { Professional Relations } \\
\text { \& Self-Development }\end{array}$ & $\begin{array}{l}\text { Permanent } \\
\text { Appointed } \\
\text { Other }\end{array}$ & $\begin{array}{l}62 \\
33 \\
20\end{array}$ & $\begin{array}{l}3.63 \\
3.65 \\
3.39\end{array}$ & $\begin{array}{l}1.0358 \\
.9140 \\
.6775\end{array}$ & .5552 & .5755 \\
\hline $\begin{array}{l}\text { School/Community } \\
\text { Relations }\end{array}$ & $\begin{array}{l}\text { Permanent } \\
\text { Appointed } \\
\text { Other }\end{array}$ & $\begin{array}{l}62 \\
33 \\
20\end{array}$ & $\begin{array}{l}3.39 \\
3.41 \\
3.10\end{array}$ & $\begin{array}{l}.9224 \\
.9238 \\
.8689\end{array}$ & .8651 & .4238 \\
\hline $\begin{array}{l}\text { Facilities \& Equipment } \\
\text { Management }\end{array}$ & $\begin{array}{l}\text { Permanent } \\
\text { Appointed } \\
\text { Other }\end{array}$ & $\begin{array}{l}62 \\
33 \\
20\end{array}$ & $\begin{array}{l}3.50 \\
3.46 \\
3.14\end{array}$ & $\begin{array}{l}.9624 \\
.8758 \\
.7243\end{array}$ & 1.2236 & .2981 \\
\hline $\begin{array}{l}\text { Business \& Financial } \\
\text { Management }\end{array}$ & $\begin{array}{l}\text { Permanent } \\
\text { Appointed } \\
\text { Other }\end{array}$ & $\begin{array}{l}62 \\
33 \\
20\end{array}$ & $\begin{array}{l}3.35 \\
3.32 \\
3.36\end{array}$ & $\begin{array}{l}1.1329 \\
1.0373 \\
.8853\end{array}$ & 0.121 & .9880 \\
\hline
\end{tabular}


TABLE 47

\section{ANOVA OF ITEMS IN CATEGORIES PROGRAM PLANNING. DEVELOPMENT. AND EVALUATION. AND INSTRUCTIONAL MANAGEMENT}

\begin{tabular}{|c|c|c|c|c|}
\hline Item Content & $\begin{array}{l}\text { Tenure in } \\
\text { Position }\end{array}$ & Mean & $\underline{E}$ & $\mathrm{p}$ \\
\hline $\begin{array}{l}\text { 9. Recommend curriculum } \\
\text { revisions }\end{array}$ & $\begin{array}{l}\text { Permanent } \\
\text { Appointed } \\
\text { Other }\end{array}$ & $\begin{array}{l}3.8361 \\
4.1212 \\
3.2500\end{array}$ & 4.6431 & .0116 \\
\hline 15. Provide student discipline & $\begin{array}{l}\text { Permanent } \\
\text { Appointed } \\
\text { Other }\end{array}$ & $\begin{array}{l}3.3710 \\
3.3750 \\
2.4500\end{array}$ & 3.9947 & .0211 \\
\hline $\begin{array}{l}\text { 25. Approve selection of } \\
\text { instructional equipment }\end{array}$ & $\begin{array}{l}\text { Permanent } \\
\text { Appointed } \\
\text { Other }\end{array}$ & $\begin{array}{l}3.7419 \\
3.6364 \\
3.0500\end{array}$ & 3.5266 & .0327 \\
\hline
\end{tabular}

\section{Hypothesis 6}

Hypothesis 6 stated: There are no significant differences among technical/vocational education administrators regarding their perceptions of professional development needs when compared to educational setting.

It should be noted that in order to make comparisons of educational setting, the original groups were re-coded. Group 1 was comprised of administrators located at Ministry of Education, tertiary institutions, and vocational centers; group 2 was made up of administrators located at Grammar schools; and group 3 constituted those administrators in the Newer secondary schools. A one-way analysis of variance test was used to identify the significant roles/functions in each category. There were no statistical 
TABLE 48

\begin{abstract}
ANOVA FOR EDUCATIONAL SETTING AND TVE ADMINISTRATORS* PERCEIVED NEED FOR PROFESSIONAL DEVELOPMENT BY MAJOR CATEGORIES
\end{abstract}

\begin{tabular}{|c|c|c|c|c|c|c|}
\hline Major Category & $\begin{array}{l}\text { Educational } \\
\text { Setting }\end{array}$ & $\underline{N}$ & Mean & $\underline{\mathrm{SD}}$ & $\underline{F}$ & $\mathrm{p}$ \\
\hline $\begin{array}{l}\text { Program Planning. } \\
\text { Development \& } \\
\text { Evaluation }\end{array}$ & $\begin{array}{l}\text { Other } \\
\text { Grammar } \\
\text { Newer }\end{array}$ & $\begin{array}{l}34 \\
29 \\
51\end{array}$ & $\begin{array}{l}3.69 \\
3.63 \\
3.73\end{array}$ & $\begin{array}{l}.8667 \\
.7616 \\
.7383\end{array}$ & .1560 & .8557 \\
\hline $\begin{array}{l}\text { Instructional } \\
\text { Management }\end{array}$ & $\begin{array}{l}\text { Other } \\
\text { Grammar } \\
\text { Newer }\end{array}$ & $\begin{array}{l}34 \\
29 \\
51\end{array}$ & $\begin{array}{l}3.58 \\
3.33 \\
3.41\end{array}$ & $\begin{array}{l}.9422 \\
.9082 \\
.8069\end{array}$ & .7434 & .4779 \\
\hline $\begin{array}{l}\text { Personnel } \\
\text { Management }\end{array}$ & $\begin{array}{l}\text { Other } \\
\text { Grammar } \\
\text { Newer }\end{array}$ & $\begin{array}{l}34 \\
29 \\
51\end{array}$ & $\begin{array}{l}3.53 \\
3.22 \\
3.33\end{array}$ & $\begin{array}{l}1.1629 \\
1.0747 \\
1.0116\end{array}$ & .6913 & .5031 \\
\hline Staff Development & $\begin{array}{l}\text { Other } \\
\text { Grammar } \\
\text { Newer }\end{array}$ & $\begin{array}{l}34 \\
29 \\
51\end{array}$ & $\begin{array}{l}3.81 \\
3.62 \\
3.82\end{array}$ & $\begin{array}{l}1.0508 \\
.9273 \\
.9261\end{array}$ & .4368 & .6472 \\
\hline $\begin{array}{l}\text { Professional Relations } \\
\text { \& Self-Development }\end{array}$ & $\begin{array}{l}\text { Other } \\
\text { Grammar } \\
\text { Newer }\end{array}$ & $\begin{array}{l}34 \\
29 \\
51\end{array}$ & $\begin{array}{l}3.70 \\
3.59 \\
3.52\end{array}$ & $\begin{array}{l}.9319 \\
.9583 \\
.9674\end{array}$ & .3876 & .6796 \\
\hline $\begin{array}{l}\text { School-Community } \\
\text { Relations }\end{array}$ & $\begin{array}{l}\text { Other } \\
\text { Grammar } \\
\text { Newer }\end{array}$ & $\begin{array}{l}34 \\
29 \\
51\end{array}$ & $\begin{array}{l}3.52 \\
3.13 \\
3.37\end{array}$ & $\begin{array}{l}.8730 \\
.9296 \\
.9172\end{array}$ & 1.4133 & .2477 \\
\hline $\begin{array}{l}\text { Facilities \& } \\
\text { Equipment } \\
\text { Management }\end{array}$ & $\begin{array}{l}\text { Other } \\
\text { Grammar } \\
\text { Newer }\end{array}$ & $\begin{array}{l}34 \\
29 \\
51\end{array}$ & $\begin{array}{l}3.29 \\
3.41 \\
3.52\end{array}$ & $\begin{array}{l}.8364 \\
.9761 \\
.9179\end{array}$ & .6542 & .5218 \\
\hline $\begin{array}{l}\text { Business \& Financial } \\
\text { Management }\end{array}$ & $\begin{array}{l}\text { Other } \\
\text { Grammar } \\
\text { Newer }\end{array}$ & $\begin{array}{l}34 \\
29 \\
51\end{array}$ & $\begin{array}{l}3.49 \\
3.44 \\
3.17\end{array}$ & $\begin{array}{l}.8725 \\
1.1213 \\
1.1329\end{array}$ & 1.1224 & .3292 \\
\hline
\end{tabular}


significant differences $(\mathrm{p}=<.05)$ found among the major categories and therefore the null hypothesis was retained. These data are summarized in Table 48.

Although significant differences were not found in the categories. one item within the category was significant. In the category Instructional Management, item 27. provide for a student record-keeping system. $\mathrm{p}=.0456 . T \mathrm{~V} E$ administrators who worked in other institutions recorded a significantly lower mean score than administrators who worked in Grammar schools or in Newer secondary schools. These data are summarized in Table 49.

TABLE 49

ANOVA OF ITEMS IN CATEGORY INSTRUCTIONAL MANAGEMENT

\begin{tabular}{lllll}
\hline \multicolumn{1}{c}{ Item Content } & Educational Setting & Mean & F & $\underline{p}$ \\
\hline 27. Provide for student & Other & 3.8824 & 3.1751 & .0456 \\
record-keeping & Grammar & 3.2414 & & \\
system & Newer & 3.3333 & & \\
\hline
\end{tabular}

\section{Summary}

In this chapter. data were presented on the characteristics of the sample of technical/vocational education (TVE) administrators, including gender, age, educational level, focus of undergraduate and graduate degree, length of time spent as an administrator, and educational setting where employed. This chapter also reported on the analysis of four research questions and six hypotheses that were tested. 
Three hypotheses were tested to determine what differences existed among technical/vocational education administrators about their perceptions on the importance of the related variables. Hypotheses 1 examined if there was any significant difference in the response of respondents about perceived roles/functions on the basis of educational background. No significant background difference emerged from the responses given in all 79 roles listed and therefore the hypothesis was retained.

In hypothesis 2. four categories were found to have significant differences. The hypothesis was retained for four categories and rejected in the remaining four categories. Significant differences were found in 12 items within the categories. In all of these roles. TVE administrators who were permanently employed and those who were appointed in their job recorded significantly higher mean responses than TVE administrators who were of "other" status and therefore attached a greater degree of importance to these.

In hypothesis 3 , five categories were found to have significant differences. Thus the hypothesis was rejected in five categories and retained in three.

Significant differences were found for 25 items within the categories. In 12 of those roles, TVE administrators who worked in "other" institutions and those who worked in Newer secondary schools recorded significantly higher mean responses than TVE administrators who worked in Grammar schools and thus attached greater level of importance to their roles. TVE administrators who worked in Grammar schools attached the least importance to these roles.

Three hypotheses were tested to determine what differences existed among technical/vocational education administrators about their perceptions of need for further 
training comparing the related variables. In hypothesis 4 , three categories were found to have significant differences. In two of the three categories. respondents with less than a B.A. and B.A. degrees expressed a significantly higher need for further preparation than respondents with graduate degrees. The hypothesis was rejected in three categories and retained in five categories.

Significant differences were found in nine items within the categories. In tive of these items. TVE administrators who had less than B.A. degrees expressed a higher degree of need for further preparation than the other TVE administrators.

Hypothesis 5 examined if there were any significant differences in the responses of respondents about perceived needs on the basis of tenure in position. No significant statistical differences were found. The hypothesis was retained for all eight categories.

Significant difference was found for three items within the categories. In two of these roles. TVE administrators who were permanently employed and those who were appointed in their job expressed a higher need for further preparation than those TVE administrators who were "other."

In hypothesis 6 , no statistically significant differences were found. The hypothesis was retained in all of the eight categories. One item within the category was significant. In item 27, provide for a student record-keeping system, TVE administrators who worked in Grammar schools and those administrators who worked in Newer secondary schools recorded a significantly higher mean score than administrators who worked in "other" institutions and thus expressed a greater need for further preparation than those TVE administrators. 


\section{CHAPTER V}

\section{SUMMARY. CONCLUSIONS. AND RECOMMENDATIONS}

The purpose of this study was to identify the range and importance of selected roles/functions of technical/vocational education administrators in Barbados and to identify their personal needs for further preparation and continuing professional development. The study also addressed the relationships between these perceptions. needs, and selected factors such as educational background. tenure in position. and educational setting.

The Barbados government is planning a general overhaul of the national schools curriculum and also there is the impending establishment of a national accreditation and certification body to deal with accreditation matters at both secondary and tertiary levels and for private and public-sector bodies. It is anticipated that the results of the study will be useful in supporting the suggested criteria for administrator certification and increase the awareness of individuals who are responsible for recruiting TVE administrators.

In addition, it is anticipated that this research will result in better managed programs of vocational and technical education through the preparation of more competent leadership personnel. It is expected that the rigorous identification of the important competencies needed by technical vocational administrators will provide a 
sound base on which (1) needs assessments can be based: (2) competency-based instructional materials can be developed. and (3) high-quality pre-service and in-service education programs can be planned and implemented.

A review of related literature suggests that it is necessary to provide leaders who can coordinate the talents and abilities of individuals for the benefit of the society. The literature also revealed that the characteristics, knowledge. and skills common to successful leaders can be acquired through planned education and training. Professional development is not a new phenomenon as over time it has been used to enable educators to acquire the competencies needed to direct activities toward satisfying student needs and also to achieve personal goals. As a consequence. it is crucial for the Ministry of Education in Barbados to implement such programs to ensure that continuing professional development needs of TVE administrators are met.

This study focused on identifying the competencies that were required by career technical/vocational education administrators in Barbados and sought to determine their perceived need for further preparation and continuing professional development. The population for the study consisted of 153 technical/vocational education administrators in the central office of the Ministry of Education of Barbados, from tertiary institutions, and also from the public secondary schools in Barbados.

The survey instrument, developed for this study, included an eight-item background section that described the sample population in terms of gender, age, years of experience as a TVE administrator, job status, description of educational setting where employed, highest degree held, and focus of undergraduate or graduate degree. In 
addition. the instrument included 79 items that described various roles/functions associated with the administration of technical/vocational education. The roles/functions were organized into the following eight categories: Program Planning, Development. and Evaluation; Instructional Management: Personnel Management: Staff Development: Professional Relations and Self-Development; School/Community Relations: Facilities and Equipment Management: and Business and Financial Management. For each role descriptor. respondents were asked to indicate the level of importance to their role as a TVE administrator and their perceived need for further preparation and continuing professional development.

To determine the level of importance, a 5-point scale was used ranging from 1 being "not important" to 5 being "very important." The mean scores for each major category and individual items within each category were rank ordered to determine the roles/functions that were perceived to be of most importance.

A second 5-point scale was used to determine the perceived need for further preparation and continuing professional development for each role descriptor. Respondents indicated their need on the scale ranging from 1 being "no need" to 5 being "high need." The mean scores for each major category and individual items within each category were rank ordered to determine the roles/functions that were perceived to be most needed for further preparation and professional development.

I requested and was granted permission by the Ministry of Education in Barbados to administer the questionnaire in the selected education institutions. An accompanying introductory letter explained (1) the general purpose of the survey, (2) the 
procedure for completing the questionnaire. and (3) the guarantee of confidentiality associated with all responses. I personally administered the questionnaires. One hundred and fifty-three technical/vocational education administrators in Barbados were surveyed. Of that number. 115 individuals participated in the study, for a response rate of $75 \%$.

\section{Findings}

Sixty percent (69) of the respondents were male and $40 \%$ (46) were female. The largest group of respondents was 46.1 percent ( 53 ) between $41-50$ years of age. Another $37.4 \%(43)$ of them were over 50 years of age. There were no respondents who reported they were less than 30 years of age.

As for their academic preparation and years of experience as a TVE administrator, 41 of the respondents $(36 \%)$ had less than a bachelor's degree $(<B$.A.). the largest group of respondents (51) had a bachelor's degree (B.A.) (44.7\%); and 22 of the respondents $(19.3 \%)$ had post-bachelor's degrees or graduate degrees (>B.A.). The average years of experience ranged from $0-5$ years to 20 or more years, with 37 respondents (32.2\%) administering TVE programs for less than 5 years. A similar number reported administering TVE programs for 6 to 10 years, and the largest group (41), or $35.7 \%$ of respondents, had administered TVE programs for over 10 years.

When asked about their educational setting, 53 respondents (46.1\%) worked in Newer secondary schools, 30 respondents (26.1\%) reported that they worked in Grammar schools, and 32 respondents (27.8\%) worked in "other" institutions which included the Ministry of Education, tertiary institutions, and vocational centers. In relation to their job 
status. 63 respondents $(54.8 \%)$ were of permanent status. 33 respondents $(28.7 \%)$ were appointed in their job. and 19 respondents (16.5\%) were of "other" status.

The descriptive analysis of the data indicated that TVE administrators perceived six of the eight major categories of administrative roles to be very important to their position (mean score on each scale was greater than 3.75 ). They perceived their job description as TVE administrators to consist of the following six functions in order of rank: (1) Professional Relations and Self-Development: (2) Staff Development: (3) Personnel Management: (4) Program Planning. Development. and Evaluation: (5) Facilities and Equipment. and (6) Instructional Management. They viewed the other two categories. School/Community Relations and Business and Financial Management. to be of little importance (mean score less than 3.76).

The high level of importance accorded to Professional Relations and SelfDevelopment is noteworthy despite the fact that there is no formally constituted professional organization of TVE administrators in Barbados and they are affiliates of general education administration organizations. In addition, $50 \%$ of the respondents indicated that the focus of their undergraduate degree was in general education when compared to the $30 \%$ in technical/vocational education. This picture is similarly reflected in the graduate degree focus where $59 \%$ reported general education and $15 \%$ technical/vocational education.

In the system of education in Barbados, the focus of the government's allocation of funds has been directed towards academic studies therefore making courses in academic subjects more available to students. This pattern is similarly extended to 
education administrators. and it is highly notable that there are no institutions of learning in Barbados or the region of the Caribbean that offer a course of study in technical/vocational education to degree level or beyond. This impacts heavily on the question of Professionalism and Self-Development. Those administrators whose degree emphasis was in technical/vocational education would have of necessity been forced to pursue their course of study outside of the region.

In addition. matters such as curriculum planning and organization. personnel selection and training. as well as aspects of facility and equipment are controlled at a national level and therefore are not part of TVE administrators' responsibilities. TVE administrators perceived these roles/functions as being important to their job and might be informing the educational authorities in Barbados that they want to play a more meaningful role in these specific areas.

Technical/vocational education administrators did not perceive School/Community Relations or Business and Financial Management as part of their job description. This is not surprising as at present educational institutions employ full-time staff who assume responsibility for business and financial matters. Unlike the United States where there are strong school/community links, the situation in Barbados is different. The link between the school and the community is usually through parent/teachers associations. Schools do not rely directly on the community for financial support but are financed through annual budgeted allocations by the central government. In examining the specific items within all eight categories, the descriptive analysis indicated that the 10 highest ranked roles/functions were: 
1. Comply with health and safety laws and regulations (item 67)

2. Develop effective interpersonal skills (item 44)

3. Assess personal performance as an administrator (item 52)

4. Guide staff in selection and using effective instructional strategies (item 18)

5. Conduct staff meetings (item 35 )

6. Assess staff-development needs (item 39)

7. Participate in professional development activities for self-improvement (item 47)

8. Develop cooperative problem-solving and decision-making skills (item 51)

9. Recommend curriculum revision (item 9)

10. Interview potential staff (item 32).

When the eight categories were reviewed for the 10 least important roles/functions, the following items were identified:

1. Direct the adult and continuing education programs (item 23)

2. Write news releases for school and area media (item 60)

3. Conduct school-orientation activities (item 28)

4. Schedule facility use by community members (item 70 )

5. Prepare renovation and alteration plan (item 71)

6. Establish purchasing and payment procedures (item 72)

7. Make informational presentations to the public (item 58)

8. Locate sources of funds for program development and operation (item 77)

9. Prepare a personnel handbook (item 31) 
10. Guide the articulation of secondary and post-secondary technical/vocational education programs (item 24).

In comparing the highest and lowest ranked individual items it should be remembered that TVE administrators perceived six of the eight categories to be very important. and in fact no category was perceived as being not important. When the mean score of the highest ranked item (item 67)--comply with health and safety laws and regulations. mean 4.61 --and the lowest ranked item (item 23)--direct the adult and continuing education programs. mean 3.23--were compared. a difference of 1.38 was noted thus indicating that the responses of TVE administrators were somewhat compact.

It is evident that TVE administrators are cognizant of the significance of occupational safety and health regulations and the strict enforcement of such regulations by relevant government authorities and by workers' organizations. This acknowledgment of the prevailing requirements might explain why TVE administrators accorded item 67 the highest ranking.

The lowest ranking, given to item 23 , can be partly explained by the fact that there are specific public centers where continuing adult education programs are administered and thus many of the schools are not involved in such programs. There were no individual items which were perceived to be "not important" to their position (mean score on each scale less than 2.50).

In reviewing the data, no significant educational background differences emerged from hypothesis 1 . TVE administrators were homogeneous in their responses 
and regarded all the categories to be important to them in their role as TVE administrators.

In hypothesis 2. which dealt with TVE administrators' perceptions on the importance of roles/functions, when compared to tenure in position. significant differences were found in four categories, Instructional Management. School/Community Relations. Facility and Equipment Management. and Business and Financial Management. Within these categories there were significant differences recorded tor some items/roles. For the category Instructional Management, in item 15. provide student discipline: item 17. prepare a master schedule: item 18. guide staff in selecting instructional strategies: and item 20. guide staff in integrating technical/vocational program. significant differences were found. In all cases TVE administrators who were "other" recorded a significantly lower mean response than those TVE administrators who were permanently employed or were appointed in their position. TVE administrators who were permanently employed and those who were appointed in their job exhibited similar characteristics in relation to the level of importance which they attached to these roles/functions. Each group recorded a higher mean score in three of six roles/functions in which they were differences than the other two groups of TVE administrators, but attached a higher level of significance in two of three roles/functions than the other two groups. Thus TVE administrators who were permanently employed and those who were appointed in their job attached a significantly higher level of importance to their roles/functions than the "other" group of TVE administrators and therefore may appear 
to have a different perception of their roles/functions from the other group of administrators.

For the category School/Community Relations. in item 53. develop a marketing plan: item 57. conduct recognition programs; and item 58, make informational presentations to the public. significant differences were found. In all cases where there were differences. TVE administrators who were "other" recorded a significantly lower mean response from TVE administrators who were permanently employed or who were appointed in their position. In all cases TVE administrators who were permanently employed and those who were appointed in their job attached a significantly higher level of importance to their roles/functions than the "other" group.

For the category Facilities and Equipment Management, in item 68, direct a safety-awareness program: item 70 . schedule facility use by community members: and item 71 , prepare renovation and alteration plans, significant differences were found. In all cases TVE administrators who were "other" recorded a significantly lower mean response than TVE administrators who were permanently employed or who were appointed in their position. In all cases TVE administrators who were permanently employed and those who were appointed in their job attached a significantly higher level of importance to their roles/functions than the "other" group.

For the category Business and Financial Management, in item 75, adopt an appropriate financial accounting system, and item 78, approve requisitions and work orders, significant differences were found. In item 75, TVE administrators of "other" status recorded a significantly lower mean response than TVE administrators who were 
permanently employed, whereas for item 78. TVE administrators of "other" status recorded a significantly different lower mean from the other two groups. In all cases TVE administrators who were permanently employed and appointed in their job attached a significantly higher level of importance to their roles/functions than the "other" group.

It must be pointed out that the "other " category is comprised of TVE administrators whose job status is either temporary or acting (substitution). As a result. there is no job security as they might be transferred to other departments and thus they might not view these roles as being important. These TVE administrators might also be new in the job and may not be knowledgeable of the roles/functions that are required to successfully perform their roles. In contrast. the permanent and appointed TVE administrators are tenured in their position and thus are settled in their career paths. This situation is reflected in the higher level of importance which they attached to these administrative roles/functions.

Significant differences on the basis of educational setting were also found for five categories. These were, Instructional Management; Personnel Management; Staff Development; School/Community Relations; and Facilities and Equipment. For the category Instructional Management, in item 15, provide student discipline; item 22. provide technical assistance in the development of customized training programs for business and industry; item 23 , direct the adult and continuing education programs, significant differences were found. In two of the three roles identified, TVE administrators of "other" status attached a significantly higher level of importance to these roles than administrators of the Newer secondary schools or the Grammar schools. 
It must be noted that "other" consists of administrators who worked in the Ministry of Education. tertiary institutions. and vocational centers in Barbados. It must further be noted that TVE administrators from Grammar schools. in all but one role. registered a significantly lower response than the other two groups of administrators. and generally displayed the least interest in these roles/functions.

For the category Personnel Management. in item 30. prepare job descriptions and requirements: item 32. interview potential staff: item 34. provide for a staff recordkeeping system: item 36. conduct staff meetings: item 37 . evaluate staff performance: and item 38. conduct staff-orientation activities. significant differences were found. In all cases TVE administrators who worked at Grammar schools attached a lower level of importance to these roles than the orher two groups of administrators. In all but two cases. TVE administrators from Newer secondary schools and "other" institutions perceived these roles as being of a higher level of importance to them than TVE administrators who worked in Grammar schools.

For the category Staff Development. in item 39, assess staff-development needs; item 40, conduct workshops and other in-service programs; item 41. arrange for workshops and in-service programs; and item 42, arrange for staff exchanges with business and industry, significant differences were found. In all cases, TVE administrators who worked at Grammar schools attached the lower level of importance to these roles whereas, interchangeably, the other two groups regarded these roles to be of the highest level of importance to their role as TVE administrators. 
For the category School/Community Relations, in item 55 . coordinate technical/vocational programs with other community job-training programs: item 58. make informational presentations to the public: and item 61. conduct open-house activities. significant differences were found. In all cases TVE administrators who worked at Grammar schools attached the lowest level of importance to these roles whereas. in four of the six roles. TVE administrators of "other" status saw these roles as being of the highest level of importance to their role as TVE administrators.

For the category Facilities and Equipment Management. in item 62. plan space requirement for programs: in item 64. develop a plan for repair and maintenance of equipment and facilities: item 65 . maintain an equipment and supply inventory system: and item 66, establish a long-range plan for acquisition of new equipment. significant differences were found. In all cases. TVE administrators who worked in Grammar schools attached the lower level of importance to these roles, whereas. in all cases but one. TVE administrators of "other" status saw these roles as being of the higher level of importance to their role as TVE administrators.

When the findings from the analysis were examined, it was interesting to note that TVE administrators who worked in Grammar schools in Barbados generally attached a significantly lower level of importance to these roles/functions and their responses were different from the other two groups of administrators. This position can be partly explained by the fact that, traditionally, in Barbados, Grammar schools were regarded as classical schools that catered to the "educational elite." These schools were established to produce clerical officials and professionals and were biased against manual labor which 
became stigmatized in Barbadian society. Thus TVE administrators of Grammar schools might have a different perception of their role than other administrators.

There were two roles in which there were exceptions to the general pattern. In item 48. model professional image through personal appearance and conduct. TVE administrators of "other" status attached a higher level of importance to this role than the other two groups of administrators. This can be explained partly by the fact that the group "other" is comprised of educational officials from the Ministry of Education and administrators who work in tertiary institutions and vocational centers. They are usually more academically. technically, and professionally qualified than the other two groups of TVE administrators and might have a more professional approach to their job than the other TVE administrators.

In item 52, assess personal performance as an administrator. TVE administrators who worked in Grammar schools and in "other" institutions attached a significantly higher level of importance to this role than did TVE administrators who worked in Newer secondary schools. It must be observed that this role is the only one in which TVE administrators who worked in Grammar schools recorded a higher mean response than the other two groups of administrators. This finding is indicative of these administrators" perception of their superiority within the "elitist" educational system in Barbados.

There are nine Grammar schools in Barbados (see Appendix B) and they are often referred to as "elite" schools (i.e., schools where the most academically gifted students attend). Curriculum changes have been slow in coming, but in recent years, 
some concessions, based on the changing nature of Barbadian society, have been granted and some measure of vocational education is taught.

On the contrary, the Newer secondary schools were established atter 1955 to cater to the less "academically gifted" student. as their curriculum placed great emphasis on vocational studies. Thus when one examines the perceived needs of TVE administrators, it is readily observed that TVE administrators in these Newer secondary schools attached a greater level of importance to these roles/functions and saw them as highly important to their job.

In the majority of cases (60\%). TVE administrators who were of "other" status. attached the highest level of importance to these roles and perceived them as highly important to their role as TVE administrators. It must be noted that in this classification of "other" are administrators from the Ministry of Education (who are the officials who are responsible for initiating and supervising the implementation of national policy). administrators of tertiary institutions (personnel who are responsible for instituting programs aimed at satisfying the staff and professional development training needs of TVE administrators); and administrators of vocational educational centers in Barbados. These findings are not surprising as these administrators are in the forefront of technicaleducational planning, implementing, and delivery within the educational system of Barbados, and the higher level of importance they attached to these roles might be reflective of the different perception they have of their roles. In addition, these TVE administrators might have different administrative responsibilities from school administrators. 
There were several areas of difference among TVE administrators in the performance of their roles/functions. There were administrative differences in the areas of Instructional Management. Schoo//Community Relations. Facility and Equipment Management. and Business and Financial Management based on tenure in position. Generally. in most of the roles where there were differences. TVE administrators who were permanently employed and those who were appointed in their job attached a higher level of importance to their job than TVE administrators who were of "other" status.

There were also administrative differences based on educational setting among TVE administrators. These administrative functions were, Instructional Management. Personnel Management. Staff Development. School/Community Relations. and Facilities and Equipment. In all five administrative areas it was noted that TVE administrators who worked in "other" and Newer secondary schools viewed their job as being of higher importance than TVE administrators who worked in Grammar schools.

Technical/vocational education administrators in Barbados seemed to have a clear perception of their role as TVE administrators and viewed the following roles as being the competencies required in the performance of their job. These were: Professional Relations and Self-Development: Staff Development; Personnel Development; Program Planning, Development, and Evaluation; Facilities and Equipment Management, and Instructional Management. In the area of Professional Relations and Self-Development, TVE administrators embraced all the competencies that were listed there and considered them as being very important to them. Among these were competencies such as develop effective interpersonal skills; assess personal 
performance as an administrator: participate in professional development: and develop cooperative problem-solving skills. In perceiving these roles as being important. TVE administrators are emphasizing that they consider self-development to be critical to their function as administrators.

Technical/vocational administrators also selected Staff Development as a very important category. They considered such roles as assessing staff development needs: evaluating staff development programs: and arranging and conducting workshops and other in-service programs as being an integral part of their function as TVE administrators. It is interesting to note that in the category Personnel Management. TVE administrators perceived roles such as conducting staff meetings: interviewing potential staff: evaluating staff performance, and assessing program staff requirements as very important functions in the performance of their job. These areas are crucial to the successful administrative function of the school.

Program Planning. Development. and Evaluation was another very important category for TVE administrators. They considered roles such as recommending curriculum revisions; surveying student interests; and preparing an annual plan for delivering technical/vocational education as being vital to the performance of their job. Similarly, in the categories of Facilities and Equipment Management, and Instructional Management, they recognized the importance of complying with safety laws and regulations, directing the safety-awareness program, guiding staff in selecting and using effective strategies, providing for student discipline, and approving the selection of 
instructional supplies/materials. Thus it can be concluded that TVE administrators in Barbados had a clear perception of their role as TVE administrators.

Technical/vocational education administrators, on the average. expressed "little need" for further preparation in the major categories of roles/functions (the mean score on most scales was between 2.51 and 3.75). The category Staff Development was the only one in which administrators expressed a high need for further preparation (mean score on scale was 3.76). This need was not expressed in the other categories.

This finding is extremely surprising as previous discussions between myself and TVE administrators and educational administrators in general seemed to indicate a need for in-service programs to satisfy the professional development needs of TVE administrators. This view is consistent with the report of the government of Barbados development plans 1965-2000. where serious concern was expressed about the need for in-service training. The report also noted that where such few programs were implemented they were regarded as deficient in quality and linked to basic levels (BOMEA. 1993, p. 55).

One is forced to question this apparent difference. I might conclude that the TVE administrators perceptions are be a reflection of their despondency. This despondency may have been brought about by an apparent sense of hopelessness in their job. the lack of job security, or the absence of job promotion within the system. The Ministry of Education has acknowledged that aspirants have left the technical/vocational education field to pursue more lucrative career paths which offer greater opportunities for upward social mobility. Contrary to the expressed views of the respondents, I share the 
opinion as expressed by education authorities and strongly believe that it is critical that the staff development needs of TVE administrators be met. Education authorities must not only provide training opportunities. but they must also. as a matter of urgency. address this perception held by TVE administrators and change such a perception.

In examining the individual roles/functions within the major categories. the 10 highest ranked items in terms of need for further preparation were:

1. Evaluate staff development programs (item 43 )

2. Develop supplemental/remedial instructional programs to meet student needs (item 12)

3. Conduct workshops and other in-service programs (item 40)

4. Direct course/program planning and development efforts (item 3)

5. Guide staff in integrating and articulation of the technical/vocational program with the total education program (item 20)

6. Assess personal performance as an administrator (item 52)

7. Assess staff development needs (item 39)

8. Recommend curriculum revisions (item 9)

9. Write proposals for the funding of new programs and the improvement of existing ones (item 10)

10. Participate in professional development activities for self-improvement (item 47).

When the eight categories were reviewed further for the 10 lowest ranked items. the following roles/functions were identified: 
1. Schedule tacility use by community members (item 70)

2. Prepare a student handbook (item 16)

3. Respond to business correspondence (item 79)

4. Approve requisition and work orders (item 78)

5. Conduct student-orientation activities (item 28)

6. Write news releases for school and area media (item 60)

7. Schedule staff workloads (item 33)

8. Conduct staff meetings (item 35 )

9. Establish student rules and policies (item 14)

10. Make informational presentations to the public (item 58).

These roles/functions are indicative of TVE administrators" perception of their job as TVE administrators and they appear to be consistent with their current job responsibilities. The highest ranked roles in terms of further preparation have been recognized by TVE administrators as being essential to their administrative roles/functions. The roles in which they expressed little need for further preparation. such as those related to school/community relations. are competencies they consider not part of their job responsibility. In comparing the mean score of the highest ranked individual item, 43 , evaluate staff development programs, 3.87 , and the lowest ranked individual, item 70 , schedule facility use by community members, 2.91 , a difference of 0.96 was noted. This result indicated that there were no great dispersions in the respondents' perceptions of expressed need for further preparation and continuing professional development. 
In relation io TVE administrators' need for further preparation and continuing professional development. there were no significant differences when respondents were compared by tenure in position and educational settings. However. when respondents were compared by educational background. some significant differences were recorded. For the category Program Planning. Development, and Evaluation, item 7. conduct student follow-up studies: item 8. assess student competency and grading procedure: and item 9. recommend curriculum revisions. significant differences are noted. In all cases TVE administrators with graduate qualifications expressed a significantly lower need for further preparation and professional development than did administrators with B.A. or less than B.A. degrees.

For the category Instructional Management. item 14, establish student rules and policies and item 28. conduct student-orientation activities, significant differences were revealed. A similar pattern emerged as TVE administrators with graduate degrees expressed a lower degree of need for further preparation and professional development than administrators with B.A. and less than B.A. degrees.

For the category Staff Development, item 40, conduct workshop and other inservice programs. was significant at the $\mathrm{p}=.05$ level. Similarly, TVE administrators with graduate degrees expressed a lower degree of need for further preparation and professional development from administrators with B.A. degrees.

In all cases, TVE administrators with less than a B.A. degree expressed a greater need for further preparation and professional development than the other two groups. This development may be partly explained by the fact that administrators with 
less than a B.A. degree would have undergone at least 2 years of skill training in technical vocational education and not administrative training. and would have received a diploma on graduation. This certification is far from adequate to prepare them for their role as TVE administrators and this factor is reflected in their high expressed need for further preparation and continuing professional development.

It should also be noted that only $30 \%$ of TVE administrators had an undergraduate focus in technical/vocational education. This may be an indication that there is a demand for academic and professional training if they are to efficiently and effectively carry out perceived roles/functions. It must be noted that TVE administrators with less than a B.A. degree expressed a higher need for further training than TVE administrators with B.A. or graduate degrees. This finding is not unexpected as. unlike the latter groups of TVE administrators who would have had some measure of training as administrators, they have not received training necessary for their job. The Ministry of Education in Barbados needs to focus its attention on this group of undergraduate TVE administrators in order to satisfy their training needs and thus adhere to their expressed views.

\section{Conclusions}

In the review of literature in chapter 2, emphasis was placed on the examination of issues related to educational administration, educational leadership/management. vocational education leadership, professional development needs, and to related studies in technical/vocational education. Limited research was available on the competencies 
required by technical/vocational education administrators in Barbados and indeed the Caribbean for their roles/functions.

The study was undertaken to better understand two areas related to the administration of technical/vocational education programs. They were (1) the perception of TVE administrators about the range and importance of their job roles/functions. and (2) their identified needs for further preparation and continuing professional development. The following conclusions are suggested by the results:

1. Leadership in technical/vocational education has emerged over the last decade as $64 \%$ of TVE administrators have reported that they have been in their positions for between $0-10$ years. This augurs well for the future as there is a solid foundation on which TY $/$ administrators can capitalize.

2. There is need for TVE administrators to be trained and certified in technical/vocation education. This is especially necessary for administrators with less than B.A. degrees and is influenced by the reported disproportionate small number of TVE administrators who had technical/vocational education training as compared to those with general educational training (see Table 8).

3. Educational background, tenure in position, or educational setting make relatively little difference to TVE administrators in their perception of the importance of roles/functions to their job as TVE administrators and also for the need for further preparation and continuing professional development. Technical/vocational education administrators have a distorted view of technical/vocational education administration. 
4. The roles/functions identified in this study have demonstrated the level of validity for the preparation and selection of TVE administrators. The roles/functions were identified from previous studies related to the administration of technical/vocational education in the United States. The data showed that all eight major categories of roles/functions were regarded by practicing administrators as having some measure of importance to their position. Six of the eight roles were embraced by TVE administrators and recognized as being very important to their function as technical/vocational education administrators. The other two, School/Community Relations and Business and Financial Management. are not major roles/functions of TVE administrators and thus are not relevant to their job.

The exclusion of these two categories is consistent with the job description of TVE administrators. In the current structure of the educational system, they play a minimal role in the business and financial management of their institutions. These institutions are supervised by a Board of Management which employs business personnel to manage its financial affairs and thus front-line administrators do not fill this role. Similarly, TVE administrators perform marginal roles in school/community relations as press releases and media contact are outside their domain. They are cognizant of the statute/legislative edict under which they function.

5. Although TVE administrators perceived the roles/functions to be very important, they do not necessarily perceive that there was a correspondingly high need for further preparation and continuing professional development in the roles/functions. There was little expressed need for further preparation and continuing professional 
development as they appear to be satisfied with their present situation. They do not regard technical/vocational education as a viable alternative to classical studies and therefore they do not need high levels of professional development to perform their administrative roles.

6. Lower levels of pre-service preparation require higher levels of in-service training.

7. Technical/vocational education administrators who work in Grammar schools in Barbados do not attach the same level of importance to their roles/functions as TVE administrators as do administrators who worked in Newer secondary schools or in "other" institutions.

8. Technical/vocational education administrators who are tenured view their administrative roles more importantly than administrators who are not tenured.

9. Technical/vocational education administrators have a clear understanding of their role as TVE administrators and their professional development needs.

\section{Reflections}

These findings have several implications for school administration in general and for TVE administrators specifically in light of the view that excellence in education as in business institutions is directly related to the quality of leadership provided by top administrators. In today's economy, population and business growth have increased demand on the telecommunication infrastructure, and opportunities for training and employment in industry have increased rapidly. Employment has shifted from 
manufacturing to the service sector and other growth occupations including trade. transportation. and communication. These jobs will require greater technical skills than previously needed. and TVE administrators must be positioned to provide the leadership to direct that movement.

What is the role of the school in the provision of these technical skills? Educational research says that effective schooling begins with an instructional leader who is "visionary" and can manage others. Business leaders say that effective schools prepare individuals for employment. They say that schools should provide students with basic skill training, and skills to seek and hold a job. In order for students to gain marketable job skills. they must be able to access education for employment programs. Should not high schools design programs which will enable students to gain both academic and employment-related skills? The answer is emphatically. yes.

What about the adult student who desires to learn a marketable job skill? The study indicated that directing adult and continuing education programs was not as important as other roles/functions for TVE administrators. These administrators did not perceive this job function as having a high need for continuing professional development. Who will serve the adult population? It is imperative that TVE administrators provide the educational training that is required and that educational authorities ensure that opportunities for such training are available. The Ministry of Education needs to conduct workshops aimed at sensitizing TVE administrators to the importance of continuing education and also widen their job responsibility to include continuing education training in order to satisfy the need. 
Secondary technical/vocational education administrators have a variety of roles/functions to perform. These administrators can be found to hold positions in the central office of the Ministry of Education. tertiary institutions. vocational centers. Grammar schools. and Newer secondary schools. Does the importance of these roles/functions vary greatly within each institution in regard to the range in size of educational programs, number of students enrolled in programs. or the number and roles/functions of other administrators within the educational setting? The study did not address these questions as they were outside its scope. but these issues should form the basis for future research.

These trends provide the framework for considering the important issues which confront technical/vocational education. They have implications for technical/vocational education programs and indeed TVE administration. TVE administrators must become technically proficient. be visionary, be able to predict future trends, and provide the type of administrative leadership that is responsive to current societal needs. Programs must be implemented to constantly monitor, to study, and to institute change when necessary.

In light of these trends, education authorities must consider the wisdom of appointing administrators only on the basis of their educational expertise. The point must be reached where training is available and potential TVE administrators can be selected on both their educational and administrative expertise. Why must central government alone be held responsible for funding such training? Why cannot business and industry assist administrators in continuing their professional development? The development of human potential seems to be the ultimate task of today's educators. Present leaders in 
technical/vocational education have a particular responsibility for developing highly motivated. able leaders with a sense of mission to improve the field and the skills to accomplish it.

\section{Recommendations}

Based on the results of this study. the following recommendations are made:

1. Higher education is seen as a limited affair. essentially academic. and somewhat ineffective to the manpower needs of the Barbadian community. As a consequence. the Barbados government through the University of the West Indies should seek to set qualifying and certification standards for TVE administrators.

2. A comprehensive program for the professional preparation of technical/vocational education administrators should be implemented in order to (a) sensitize them more fully to their role. and (b) improve their competence on the job.

3. Institutions which prepare secondary-school administrators should develop a mechanism that will provide for the continual updating and revision of administrative preparation courses so as to respond to the identified roles and functions of TVE administrators.

4. The Ministry of Education should appoint an advisory group of practicing TVE administrators to conduct wide-scale workshops and seminars to deal with weaknesses where observed, or to focus on continued professional development. 
5. Barbados scholarships and bursaries should be offered in the area of technical/vocational education and thus provide funding for individuals who want to pursue undergraduate training in the field.

6. Undergraduate and graduate degree programs should be introduced at the University of the West Indies in order to provide training relevant to available educational opportunities.

7. Follow-up assistance should be provided. geared at working with TVE administrators to determine how to make use of their new knowledge and skills they have acquired from new training and technical updating.

8. Closer links should be established between education and training systems by setting up training posts in firms, coordinated by the Ministry of Education, in order that prospective TVE administrators be provided with clinical and administrative experience.

9. TVE administrators should establish professional groups aimed at their continuing professional development through discussion of common problems, exchange of new ideas, and the discussion of research finding.

10. Education institutions should forge more meaningful school/community linkages in order to market technical/vocational education and to solicit financial support to satisfy training needs.

In considering future research as a result of this study, the following recommendations are presented: 
1. There should be an on-going university-based research effort to study the changing role expectations for technical/vocational education administrators as well as their need for further preparation.

2. Research should be carried out in order to ascertain the future employment needs of the country in order to devise curriculum strategies to meet such needs.

3. A similar study could be done in the primary-school setting in order to compare such findings with the findings of this study.

4. An alternative method of research should be done to determine what competencies are needed by TVE administrators to satisfy their professional development needs.

5. Research should be done in order to determine the roles/functions of other administrators within the educational setting. 
APPENDIX

Reproduced with permission of the copyright owner. Further reproduction prohibited without permission. 
APPENDIX A

\section{LETTERS}

Reproduced with permission of the copyright owner. Further reproduction prohibited without permission. 


Andrews University, Burman Hall 203 Berrien Springs MI 49104

May 4, 1995

Permanent Secretary

Ministry of Education

Bridgetown, Barbados

Attn: Mrs. Hinkson

Dear Mrs. Hinkson,

I the undersigned am pursuing a Ph.D Degree in Educational Administration and Supervision at Andrews University, Berrien Springs, Michigan. I have chosen to do my dissertacion in an area that is relevant to education in Barbados. The topic of my study is Selected Roles/Functions of Technical/Vocational Education Administrators in Barbados and the Need for Further Preparation and Continuing Professional Development.

In order to do my research, the Human Subjects Review Board of the University requires a letter indicating that permission is granted to conduct the survey in educational institutions in Barbados. I anticipate collecting information from rechnical/vocation education administrators in the Ministry of Education, Tertiary Institutions, and secondary Schools where technical/vocational education is delivered.

Please fax information or reply to Cecil Cummins, c/o Dr. Lyndon Furst, School of Education, Andrews University, Berrien Springs, MI, 49104. The fax number is (616) 471-6374.

Thank you in advance for your cooperation. Sincerely,

Cecil I. Cumins, Ph.D Candidate 
CUMMINS

Andrews University, Burman Hall 203

Berrien Springs MI 4910

May 4, 1995

Technical/Vocational Education Administrators

Ministry of Education

Tertiary Institutions

Secondary Schools

Dear ,

I am a member of the Barbados Vice-Principals Association and I am currently conducting a research study in order to better understand the perceptions of practicing Technical-Vocational Education Administrators in Barbados, about the range and importance of selected roles/functions; and personal needs for further preparation and continuing professional development.

The findings and analysis from the study will be useful in supporting the suggested criteria for administrator

certification, and in increasing the awareness of individuals who are responsible for recruiting trained-vocational education administrators.

Please help me in this important research by taking approximately 15-20 minutes of your valuable time to complete the survey instrument. I plan to be in Barbados May 8-17 and would be pleased to meet with you during that period. Your individual responses to this survey will remain confidential.

Thank you in advance for your consideration and cooperation.

Sincerely,

Cecil I. Cummins, Ph.D Candidate

Education Administration and Supervision

Andrews University

enc. 
APPENDIX B

LIST OF SCHOOLS

Reproduced with permission of the copyright owner. Further reproduction prohibited without permission. 


\section{GOVERNMENT SECONDARY SCHOOLS}

GRAMMAR SCHOOLS

HARRISON COLLEGE

QUEEN'S COLLEGE

COMBERMERE

ST. MICHAEL'S

LODGE

ALEXANDRA

COLERIDGE \& PARRY

FOUNDATION

ALLEYNE

\section{NEWER SECONDARY}

DEIGHTON GRIFFITH

ELLERLISE SECONDARY

GARRISON SECONDARY

GRANTLY ADAMS MEMORIAL

LOUIS LYNCH SECONDARY

PARKINSON SECONDARY

PRINCESS MARGARET

ST. GEORGE SECONDARY

ST. JAMES SECONDARY

ST. LEONARD'S BOYS

ST. LEONARD'S GIRLS

ST. LUCY SECONDARY

SPRINGER MEMORIAL 


\section{APPENDIX C}

SURVEY 


\section{SURVEY QUESTIONNAIRE}

PREPARATION AND CONTINUING PROFESSIONAL DEVELOPMENT NEEDS

OF TECHNICALNOCATIONAL EDUCATION ITVE ADMINISTRATORS

OIRECTIONS:

For each role descriptor, please provide two pieces of information: 1) IMPORTANCE TO YOUR ROLE AS A TVE ADMINISTRATOR.

(Please indicate how important this roleffunction is to your success as an administrator. Remember that we are looking for perceptions based on individual situation); and 2) YOUR PERSONAL NEED FOR FURTHER PREPARATION AND CONTINUING PROFESSIONAL

DEVELOPMENT. (Please indicate the degree to which you feel a need for further continuing professional development in order to be as effective as you would like to be in each of the rolelfunctions listed). Circle only one response for each function.

IMPORTANCE TO ROLE AS

A TVE ADMINISTRATOR

Not Important 12345 Very Important
MEED FOR FURTHER PREPARATION AND CONTINUING PROFESSIONAL DEVELOPMENT

No Need 12345 High Need

PROGRAM PLANNING. DEVELOPMENT AND

EVALUATION

1. Survey student interests.

2. Analyze labor demand data

3. Direct course/program planning and development efforts.

4. Prepare an annual plan for delivering technical-vocationall education.

5. Prepare a 3.5 year plan for overall program improvernent.

6. Conduct course/program reviews.

7. Conduct student follow.up studies.

8. Assess student competency and grading procedures.

9. Recommend curriculum revisions.

10. Write proposals for the funding of new programs and the improvement of existing programs.

11. Contract instructional programs with business and industry.

12. Develop supplementallremedial instructional programs to meet student needs. $\begin{array}{lllll}1 & 2 & 3 & 4 & 5\end{array}$

12345

12345

12345

$123 \quad 3 \quad 5$

12345

$\begin{array}{lllll}1 & 2 & 3 & 4 & 5\end{array}$

$\begin{array}{lllll}1 & 2 & 3 & 4 & 5\end{array}$

12345

12345

12345

$\begin{array}{lllll}1 & 2 & 3 & 4 & 5\end{array}$ $\begin{array}{lllll}1 & 2 & 3 & 4 & 5\end{array}$

12345

$\begin{array}{lllll}1 & 2 & 3 & 4 & 5\end{array}$

12345

12345

12345

12345

12345

12345

12345

$\begin{array}{lllll}1 & 2 & 3 & 4 & 5\end{array}$

12345 


\section{INSTRUCTIONAL MANAGEMENT}
13. Establish instructional program entry and completion requirements.
12345
12345
14. Establish student rules and policies.
12345
15. Provide student discipline.
$\begin{array}{lllll}1 & 2 & 3 & 4 & 5\end{array}$
$\begin{array}{lllll}1 & 2 & 3 & 4 & 5\end{array}$
16. Prepare a student handbook.
12345
$\begin{array}{lllll}1 & 2 & 3 & 4 & 5\end{array}$
17. Prepare a master schedule of
12345
$\begin{array}{lllll}1 & 2 & 3 & 4 & 5\end{array}$ course/program offerings.
18. Guide staff in selecting and using effective instructional strategies.
12345
$\begin{array}{lllll}1 & 2 & 3 & 4 & 5\end{array}$
19. Direct the cooperative education program.
20. Guide staff in integrating and articulating the technical-vocational program with the total educational program.
21. Promote the integration of vocational student organizational activities within the instructional program.
22. Provide technical assistance in the development of customized training programs for business and industry.
23. Direct the adult and continuing education programs.
24. Guide the articulation of secondary and postsecondary technical-vocational education programs.
25. Approve selection of instructional equipment.
26. Approve selection of instructional supplies and materials.
27. Provide for a student record-keeping system.
28. Conduct student orientation activities.

\section{PERSONNEL MANAGEMENT}
29. Assess program staffing requirements.
$\begin{array}{lllll}1 & 2 & 3 & 4 & 5\end{array}$
12345
30. Prepare job descriptions and
12345
12345 
31. Prepare a personnel handbook.

32. Interview potential staff.

33. Schedule staff work loads.

34. Provide for a staff record-keeping system.

35. Conduct staff meetings.

36. Prepare bulletins and other communications designed to keep staff informed.

37. Evaluate staff performance.

38. Conduct staff orientation activities. $\begin{array}{lllll}1 & 2 & 3 & 4 & 5\end{array}$

12345

12345

12345

12345

$\begin{array}{lllll}1 & 2 & 3 & 4 & 5\end{array}$

$\begin{array}{lllll}1 & 2 & 3 & 4 & 5\end{array}$

$\begin{array}{lllll}1 & 2 & 3 & 4 & 5\end{array}$
12345

12345

$\begin{array}{lllll}1 & 2 & 3 & 4 & 5\end{array}$

$\begin{array}{lllll}1 & 2 & 3 & 4 & 5\end{array}$

$\begin{array}{lllll}1 & 2 & 3 & 4 & 5\end{array}$

$\begin{array}{lllll}1 & 2 & 3 & 4 & 5\end{array}$

$\begin{array}{lllll}1 & 2 & 3 & 4 & 5\end{array}$

$i 2345$

\section{STAFF DEVELOPMENT}

39. Assess staff development needs.

40. Conduct workshops and other inservice programs.

41. Arrange for warkshops and inservice programs.

42. Arrange for staff exchanges with business and industry.

43. Evaluate staff development programs.
12345

$\begin{array}{lllll}1 & 2 & 3 & 4 & 5\end{array}$

12345

12345

12345 $\begin{array}{lllll}1 & 2 & 3 & 4 & 5\end{array}$

12345

$\begin{array}{lllll}1 & 2 & 3 & 4 & 5\end{array}$

$\begin{array}{lllll}1 & 2 & 3 & 4 & 5\end{array}$

$\begin{array}{lllll}1 & 2 & 3 & 4 & 5\end{array}$

\section{PROFESSIONAL RELATIONS AND SELF.}

DEVELOPMENT

44. Develop effective interpersonal skills.

$\begin{array}{lllll}1 & 2 & 3 & 4 & 5\end{array}$

12345

45. Participate in professional organizations related to technical-vocational

12345 education.

46. Participate in professional organizations other than technical-vocational education.

47. Participate in professional development activities for self-improvernent.

$123 \quad 3 \quad 4 \quad 5$

$\begin{array}{lllll}1 & 2 & 3 & 4 & 5\end{array}$

48. Model professional image through personal appearance and conduct.

49. Apply information from professional joumals, reports and related materials for self-improvement.

50. Apply time management techniques to personal work assignments. 
51. Develop cooperative problem solving and decision-making skills.

52. Assess personal performance as an administrator. $\begin{array}{lllll}1 & 2 & 3 & 4 & 5\end{array}$

12345
12345

$\begin{array}{lllll}1 & 2 & 3 & 4 & 5\end{array}$

\section{SCHOOL-COMMUNITY RELATIONS}

53. Develop a marketing plan for promoting technical-vocational education.

54. Participate in community activities.

55. Coordinate technical-vocational education programs with other community job training programs

56. Involve community leaders (political and nanpoliticall in school programs and activities.

57. Conduct recognition programs for students, staff and community supporters.

58. Make informational presentations to the public.

59. Plan for exhibits and displays.

60. Write news releases for school and area media.

61. Conduct open house activities.

\section{FACIUITIES AND EQUIPMENT}

62. Plan space requirements for programs.

$\begin{array}{lllll}1 & 2 & 3 & 4 & 5\end{array}$

$\begin{array}{lllll}1 & 2 & 3 & 4 & 5\end{array}$

63. Submit building and equipment

$\begin{array}{lllll}1 & 2 & 3 & 4 & 5\end{array}$

12345 specifications.

64. Develop a plan for repair and maintenance of equipment and facilities.

12345

12345

65. Maintain an equipment and supply

12345

12345 inventory system.

66. Establish a long-range plan for acquisition of new equipment.

67. Comply with health and safety laws and regulations.

$\begin{array}{lllll}1 & 2 & 3 & 4 & 5\end{array}$

12345

68. Direct a safety awareness program.

$123 \quad 4 \quad 5$

12345

69. Establish emergency plans (such as fire and disasterl. 
70. Schedule facility use by community members.

71. Prepare renovation and alteration plans.

BUSINESS AND FINANCIAL MANAGEMENT

72. Establish purchasing and payment procedures.

73. Prepare budgets.

74. Administer budgets.

75. Adopt an appropriate financial accounting system.

76. Analyze the cost of operating various instructional programs.

77. Locate sources of funds for program development and operation.

78. Approve requisitions and work orders.

80. What is your gender?
a. - male
b. — female

81. What is your age group?
a. - under 30 years of age
b. - 31 to 40 years of age
c. - 41 to 50 years of age
d. - 51 to 55 years of age
e. - over 55 years of age

82. How long have you been an administrator of vocational-technical education programs?
a. -0.5 years
b. -6.10 years
c. -11.15 years
d. $-16 \cdot 20$ years
e. - over 21 years

83. At present, what is your job status?
a. - temporary
b. - permanent
c. — acting
d. - appointed
e. - other 
84. At present from what type of educational setting are you employed.
a. - Ministry of Education
b. - Tertiary Institution
c. — Vocational Center
d. _ Grammar School
e. - Newer Secondary

85. At present, what is the highest level of education received?
a. - " 0 " or "A" levels
b. - Diploma
c. - B.A.
d. - M.A.
e. - Doctorate degree

86. What was your major focus of study in your undergraduate degree program?
a. - general education
b. - vocational education
c. — special education
d. - other

87. What was your major focus of study in your graduate degree program?
a. - general education administration
b. - vocational education administration
c. - special education administration
d. - guidance and counseling
e. - other 
SELECTED BIBLIOGRAPHY 


\section{SELECTED BIBLIOGRAPHY}

Aitken. H. P. (1992). Leadership, learning, and renewal: A study of the attitudes and opinions expressed by independent school heads concerning their own professional development. Paper presented at the annual meeting of the American Educational Research Association, San Francisco, CA.

Aldekhyyel, N. A. (1988). Competencies needed by vocational and technical education administrators in the kingdom of Saudi Arabia. Unpublished doctoral dissertation. Florida State University.

Anderson. W. L. (199l). An analysis of the roles of high school administrators as perceived by principals and assistant principals in selected Oklahoma public high schools. Unpublished doctoral dissertation. University of Oklahoma.

Bacchus. M. K. (1980). Education for development or underdevelopment? Waterloo: Wilfred Laurier University Press.

Badaway, M. K. (1982). Developing managerial skills in engineers and scicntists New York: Van Nostrand Reinhold.

Barbados Office of Ministry of Economic Affairs. (1973). Government Development Plans 1973-1977. Bridgetown: Government Printing Press.

Barbados Office of Ministry of Economic Affairs. (1988). Government Development Plans 1988-1993. Bridgetown: Government Printing Press.

Barbados Office of Ministry of Economic Affairs. (1993). Government Development Plans 1993-2000. Bridgetown: Government Printing Press.

Barbados Office of Ministry of Education and Culture. (1993). The initial and continuing education of teachers in Barbados: A case study. Bridgetown: Government Printing Press.

Barnard, C. I. (1962). Organization and management. Cambridge, MA: Harvard University Press. 
Bass. B. M.. \& Stogdill. R. M. (1981). Stogdill's handbook of leadership: At survey of theory and research (Rev. ed.). New York: Free Press.

Beckford, G. L. (1972). Persistent poverty: Underdevelopment in plantation economies of the Third World. New York: Oxford University Press.

Behrman. J. N.. \& Levin. R. L. (1984). Are business schools doing their job? Harvard Business Review. 62(1). 140-147.

Bennis. W. (1984). The four competencies of leadership. Training and Development Journal. 39(8). 15-19.

Bennis, W. G., \& Nanus, B. (1985). Leaders: The strategies for taking charge. New York: Harper \& Row.

Borg. W. R. (1981). Applying educational research: A practical guide for teachers. New York: Longmans.

Bottoms. G. (1975). Responsibilities of local schools systems. State Department of Education, institutions of higher education and professional organization for inservice education. In Rethinking In-Service Education. Washington. DC: National Education Association.

Boulding, K. E. (1972. Winter). The schooling industry as a possibly pathological section of the American economy. Review of Educational Research, 2f(1), 133-134.

Boyer, E. L. (1983). At report on secondary education in America. New York: Harper \& Row.

Brandewie, D., Johnson, T., \& Trump, J. L. (1972, March). The preparation and development of secondary school administrators. NASSP Bulletin. 24.

Brathwaite, L. (1958, March). The development of higher education in the West Indies. Social and Econonic Studies, 7, 1.

Burns, J. M. (1984). Foreword in Kellerman, B. (Ed.), Leaders' multidisciplinary perspectives. Englewood Cliffs, NJ: Prentice Hall.

Burns, J. M. (1978). Leadership. New York: Harper \& Row 
Burns. J. (1992). Selected roles/functions of Michigan career-technical vocational administrators: At study of perceived needs for preparation and continuing professional development. Unpublished doctoral dissertation. Michigan State University.

Caffrey, R. J. (1989). An investigation of management skills of Connecticut public schools administrators. Unpublished doctoral dissertation. University of Connecticut.

Campbell. D. P. (1984). Foreword in W. E. Rosenbach \& R. L. Taylor. comtemporary issucs in Leadership. London: Westview Press.

Campbell. J. P.. Dunnette. M. D.. Lawler. E. E., \& Weick. K. E. (1970). . Kanagerial behavior. performance. and effectiveness. New York: McGraw-Hill.

Campbell. R. F., \& Gregg. R. T. (1957) (Eds.). Administrative behavior in education. New York: Harper and Brothers Publishers.

Cohen. M. (1981). Effective schools: What the research says. Today's Education. $-0,466-469$.

Combrink. D. E. (1983). The identification and verification of competencies important to secondary and postsecondary administrators of vocational education in Arizona. Flagstaff, AZ: Northern Arizona University.

Crudup, S. (1991). The role of the local vocational education director in North Carolina. Unpublished doctoral dissertation. North Carolina State University.

Cunningham, L. L. (1985. September). Leaders and leadership: 1985 and beyond. Phi Delta Kappan, 67(l), 17-20.

Drucker, P. (1954). The practice of management. New York: Harper \& Row.

Drucker, P. (1986). Managing for results. New York: Harper \& Row.

Dunham, R. B., \& Pierce, J. L. (1989). Management. Glenview, IL: Scott, Foresmam.

Edelfelt, R. A., \& Johnson, M. (1975). (Eds.). Rethinking in-service education. Washington, DC: National Education Association. 
Edelfelt. R. A.. \& Lawrence. G. (1975). In-service education: The state of the art in rethinking in-service education. Washington. DC: National Education Association.

Edmunds. N. (1988). Developing leaders: Why we must. how we can. locational Education Journal. 63(8), 24-25.

Fielding. G.. \& Del Schalock. H. (1985). Promoting the professional development of teachers and administrators. Eugene. OR: Center for Education Policy and Management.

Francis. V.. et al. (1994). Reforming technical and vocational training in public secondary schools. Government of Barbados. Ministry of Education and Culture. Bridgetown: Government Printing Press.

Freshour. D. J. (1990). Emphasis on and training for instructional leadership among secondary administrators in Northern Rocky Mountain States. (Idaho, Wyoming, Montana). Unpublished doctoral dissertation. University of Montana.

Goodridge. R. V. (1985). The Chief Education Officer in the Caribbean context. Caribbean Journal of Education, 12(1,2), 79-89.

Gordon. S. C. (1968). Reports and repercussions in West Indian education. 18351933. London: Ginn \& Co.

Harbison. F.. \& Myers. C. A. (1959). Management in the industrial world: An international analysis. New York: McGraw-Hill.

Harris, B. M. (1980). Improving staff development through in-service education. Boston: Allyn \& Bacon.

Hatch-Yap, C. M. (1988). A study of principals' perception of their role and their educational administration programs' perceived effectiveness as related to that role. Unpublished doctoral dissertation, Saint Louis University.

Hawley, W. D. (1988). Missing pieces in the educational reform agenda: Or why the first and second waves may miss the boat. Educational Administration Quarterly. $24,416-437$.

Haye, W. I. S. (1976). A model for a leadership development component of vocational agriculture programs in Jamaica. Unpublished doctoral dissertation, Iowa State University. 
Heisler. W. J.. \& Lasher. H. J. (in press). The business of management development and management education: A call for increased collaboration. Journal of Management Development.

Hemphill. J. K.. \& Coons. A. E. (1957). Development of the leader behavior questionnaire. In R. M. Stogdill and A. E. Coons (Eds.), Leader hehavior: Its description and measurcment. Columbus. $\mathrm{OH}$ : Bureau of Business Research. Ohio State University.

Hersey. P.. \& Blanchard. K. H. (1982). The management of organizational behavior (4th ed.). Englewood Cliffs. NJ: Prentice Hall.

Jacobs. T. O.. \& Jaques. E. (1990). Leadership in complex systems. In J. Zeidner (Ed.). Human productivity enhancement: Organization, personnel, and decision making (Vol. 2. pp. 7-65). New York: Praeger.

James. O. H. (1976). A proposal for the professional preparation of secondary school principals in Jamaica. Unpublished doctoral dissertation. Columbia University Teachers College.

James-Reid. O. (1985). Training school principals: A timely plea. Caribbean Journal of Education. 9(3), 229-242.

Jenkins, H. O. (1991). Getting it right: A handbook for successful school leadership. Oxford: Basil Blackwell.

Johnston. J. S., Jr. (1986). Educating managers: Executive effectiveness through liberal learning. San Francisco: Jossey Bass.

Kellerman, B. (1984). (Ed.). Leaders' multidisciplinary perspectives. Englewood Cliffs. NJ: Prentice Hall.

Lawrence, G. (1974). Pattern of effective in-service education: A state of art summary of research on materials and procedures for changing teacher behaviors in inservice education. Gainesville: University of Florida, College of Education. (Eric Document Reproduction Service No. ED 176424)

Lemmer, J. L. (1992). Comparing the perceptions of public and Catholic elementary school principals about the relative and amounts of time spent on various administrative vunctions. Unpublished doctoral dissertation, The University of Nebraska, Lincoln. 
Lester. R. I. (1981, November). Leadership: Some principles and concepts. Personnel Journal, 60(11), 868-870.

Little. J. K. (1970. November). Leadership as viewed by a psychologist. At seminar on graduate education programs (J. P. Arnold. Ed.). Columbus. $\mathrm{OH}$ : Center for Vocational and Technical Education.

Massie. J. L. (1971). Essentials of management (2nd ed.). Englewood Cliffs. NJ: Prentice-Hall.

Manz. C.. \& Sims. H. P.. Jr. (1986). Beyond imitation: Complex behavioral and affective linkages resulting from exposure to leadership training models. Journal of Applied Psychology. 7 l(4), $571-578$.

McGehee. W.. \& Thayer. P.W. (1961). Truining in business and industry. New York: Wiley.

Meade. E. L. (1971). No health in us. In L. J. Rubin (Ed.). Improving inservice education: Proposals and procedures for change. Boston: Allyn \& Bacon.

Miller. B. A. (1985). The Caribbean at the crossroads and its implications for education. Caribbean Journal of Education. 12,(1,2), viii-xii.

Miller. E. (1985). Nature and needs of educational administration in the commonwealth Caribbean. Caribbean Journal of Education. 12(1.2), 27-42.

Mintzberg, H. (1972). The nature of managerial work. New York: Harper \& Row.

National Commission on Excellence in Education. (1975). Continuing the search: Preservice and in-service education. Reston. VA: National Association of Secondary School Principals.

National Commission on Excellence in Education. (1983). A nation at risk. Washington. DC: National Association of Secondary School Principals.

Niehouse. O. L. (1988, February). Leadership concepts for principals: A practical approach. NASSP Bulletin, 26, 71.

Norton, R. E., et al. (1987). The identification and national verification of competencies important to secondary and postsecondary administrators of vocational education. Ohio State University: National Center for Research in Vocational Education. 
Peters. T. (1988). In search of excellence: A talk with Tom Peters. NASSP Bulletin. $72(512), 36-45$.

Prosser. C. A.. \& Quigley. T. H. (1963). Vocational education in a democracy. (Rev. ed.). Chicago: American Technical Society.

Rauch. C. F., \& Behling. O. (1984). Functionalism: Basis for an alternate approach to the study of leadership. In J. G. Hunt. D. M. Hosking. C.A. Schriesheim. \& R. Steward (Eds.). Leaders and managers: International perspectives on managerial behavior and leadership (pp. 45-62). Elmsford. NY: Pergamon Press.

Sagen. H. B. (1981). Crucial issues in education (7th ed.). New York: Holt. Rinehart \& Winston.

Schein. E. H. (1972). Professional education. Los Angeles: The Carnegie Commission on Higher Education.

Schein. E. H. (1984, August). Management development: What is management? What is development? Paper presented at the 44th Annual Meeting of the National Academy of Management. Boston. MA.

Schon. D. A. (1983). The reflective practitioner: How professionals think in action. New York: Basic Books.

Showers, B., Joyce. B.. \& Bennett, B. (1987). Synthesis of research on staff development: A framework for future study and a state-of-art analysis. Educational Leadership, $\$ 5(3), 77-87$.

Sparks. G. (1983). Synthesis of research on staff development for effective teaching. Educational Leadership, $+I(3), 65-72$.

Sparks. D., \& Loucks-Horsley, S. (1989). Five models of staff development for teachers. Journal of Staff Development, I0 (4). 28-31.

Sparks, G. M. (1987). Promoting the professional development of teachers in career ladders. Oxford, $\mathrm{OH}$ : National Staff Development Council.

Stogdill, R. M. (1974) Stoghill's handbook of leadership. New York: Free Press.

Tannenbaun, R., Weschler, I., \& Massarik, F. (1961). Leadership and organization: A behavioral science approach. New York: McGraw Hill. 
Tead. O. (1935). The art of leadership. New York: McGraw-Hill.

Tuckman. B. W. (1978). Conducting educational research (2nd ed.). New York: Harcourt. Brace. Jovanovich.

Tyler, R. W. (1970). In-service education for teachers: A look at the past and future. In L. J. Rubin (Ed.), Improving inservice education: Proposals and procedures for change. Boston: Allyn \& Bacon.

Ubben. G. A.. \& Hughes. L. W. (1992). The principal: Creative leadership for effective schools (2nd ed.). Boston: Allyn and Bacon.

University Council for Educational Administration. (1973). The preparation and certification of educational administrators. Columbus. Ohio: University Council for Educational Administration.

Vaill. P. (1983). The theory of managing in the managerial competency movement. The Organizational Behavior Teaching Journal. 8(2). 50-54.

Vineyard. E. E. (1993). The pragmatic presidency: Effective leadership in the two yearcollege. Bolton. MA: Anker Publishing Company.

Waters, J. A. (1980). Managerial skill development. Academy of Management Review. $5,449-453$.

Weber, C. A., \& Weber. M. E. (1961). Fundamentals of educational leadership. New York: Exposition Press.

Wenrich, R. C.. \& Wenrich. J. W. (1974). Leadership in administration of vocational and technical education. Columbus, $\mathrm{OH}$ : Charles E. Merrill.

Wexley, K. N. (1984). Personnel training. Annual Review of Psychology, 35, 519-551.

Wexley, K .N., \& Latham, G.P. (1981). Developing and training human resources in organizations. Glenview, IL: Scott-Foresman.

Wexley, K. N., \& Baldwin, T. J. (1986). Management development. Journal of Management, 12(2), 277-294.

Williams, E. (1968). Education in the British West Indies. New York: University Place Bookshop. 
Wilson. B. L., \& Rossman. G. B. (1993). Mandating academic excellence: High school responses to state curriculum reform. New York: Teachers' College Press. Teachers College. Columbia University.

Yammarino. F. L., \& Bass. B. M. (1988). Long-term forecasting of transformational leadership and its effects among naval officers: Some preliminary findings. Paper submitted to the Conference on Psychological Measures and Leadership. San Antonio.

Yukl. G. (1994). Leadership in organizations (3rd ed.). Englewood Cliffs. NJ: Prentice Hall. 
VITA

NAME:

DATE OF BIRTH:

PLACE OF BIRTH:

EDUCATION:

1997

1992

1989

1982

1980

WORK EXPERIENCE:

1983

1984-1994

\section{CECIL I. CUMMINS}

December 22, 1947

St. Thomas, Barbados

Doctor of Philosophy

Educational Administration and Supervision Andrews University, Berrien Springs,

Michigan, USA

Education Specialist

Educational Administration and Supervision Andrews University, Berrien Springs,

Michigan, USA

Master of Arts, Educational Administration and Supervision, Andrews University, Berrien Springs, Michigan, USA

Diploma in Education (Distinction) U.W.I., Cave Hill, Barbados

Bachelor of Arts, History, Government and Sociology (Lower Second Class Honors) U.W.I., Cave Hill. Barbados

Vice Principal, Seventh-day Adventist Secondary School Barbados

Business Manager, Seventh-day Adventist Secondary School, Barbados 
$1989-1990$

Graduate Assistant, School of Education, Andrews University, Berrien Springs, Michigan, USA

1976-1983

Head of Arts and General Studies Department, Seventhday Adventist Secondary School, Barbados

$1966-1976$

Teacher, Seventh- day Adventist Secondary School, Barbados

$1964-1966$

Supernumerary Teacher, Ministry of Education, Barbados

PROFESSIONAL ASSOCIATION:

1989

Phi Delta Kappa

1984

Member of Education Committee, Partners of Americas, Barbados- Albany, New York Chapter, USA.

EXTRACURRICULAR:

1997

President, Melrose Football Club, Barbados

1982-1985

Secretary, Hillaby Sports and Cultural Club, Barbados

1980

President, U.W.I. Cricket Club, Barbados 